Gabriel Rabelo Neves

Identidade Visual
do bar Ovelha Negra

Brasília - DF

Junho de 2008 
Gabriel Rabelo Neves

\section{Identidade Visual do bar Ovelha Negra}

Trabalho de Conclusão de Curso (TCC), apresentado como requisito para a obtenção de título de Bacharel em Desenho Industrial com habilidade em Programação Visual pela Universidade de Brasília.

Orientadora: Virgínia Tiradentes

Brasília - DF Junho de 2008 


\section{SUMÁRIO}

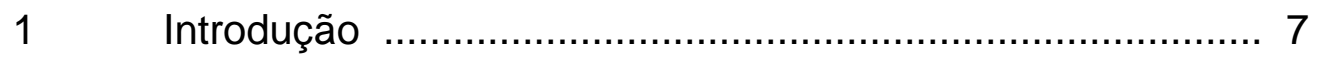

2 Levantamento de Dados ……………......................... 9

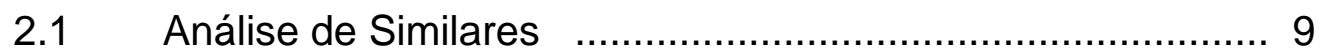

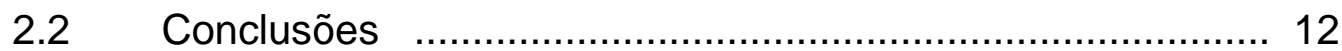

2.3 Análise do Conteúdo dos Sites ...................................... 12

2.4 Marcas de outros lugares chamados Ovelha Negra ........... 14

2.5 Outras representações com ovelhas negras ....................... 14

2.6 Similares de Brasília ......................................................... 15

2.7 Pesquisa com Público-Alvo …............................................ 17

2.7.1 Perguntas da Entrevista …….................................... 18

2.7.2 Resultados ....................................................... 19

2.7.3 Conclusão da Pesquisa com Público-Alvo ....................... 24

$3 \quad$ Requisitos do Projeto ….............................................. 25

$4 \quad$ Geração de Alternativas ................................................... 26

4.1 Ilustração da parede e do jogo americano ......................... 26

4.1.2 Conclusão da geração da ilustração ……......................... 28

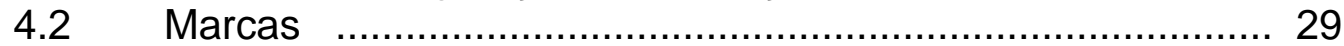

4.2.1 Conclusão da geração da marca ….................................... 40

4.3 Cartão Corporativo .......................................................... 40

4.4 Portas-Copo ………............................................. 42

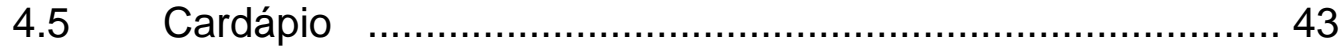

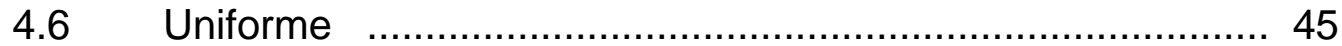

$4.7 \quad$ Leiaute do site …...................................................... 46

4.8 Definição do padrão cromático …………...................... 52

4.9 Definição do padrão tipográfico ………............................ 53

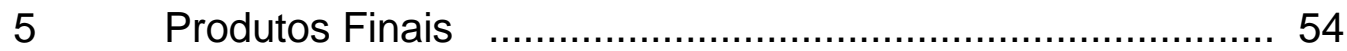

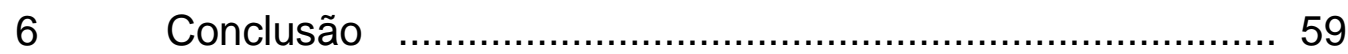

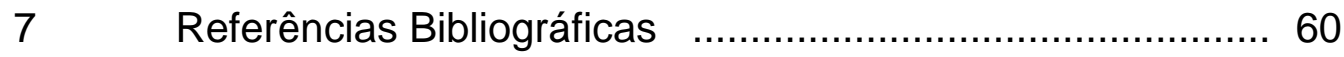

Apêndice A Análise detalhada do conteúdo dos sites ................. 61 Apêndice B Manual da marca para entrega ao cliente ................... 70 


\section{Resumo}

O objetivo do presente trabalho é o desenvolvimento da Identidade Visual do bar Ovelha Negra. Para isso, foi feita primeiramente uma pesquisa de bares e suas marcas. Com o resultado da pesquisa, que concluiu a existência de inúmeros bares com esse mesmo nome por todo o mundo. A partir de então, fez-se uma análise detalhada das marcas desses bares e de outras ocorrências de ovelhas negras em composições visuais. Paralelamente a isso, foi feita uma pesquisa com o público-alvo em bares de Brasília, aproveitando-se para analisar a decoração de bares escolhidos de acordo com o conceito estabelecido para o bar pelo cliente. Terminada a etapa de levantamento de dados, partiu-se para a geração de alternativas para a marca de acordo com os requisitos estabelecidos. Definidas a marca, as cores da Identidade e a tipografia a serem utilizadas; iniciou-se o processo de criação dos produtos demandados na seguinte sequiência: cartão corporativo, porta-copo, cardápio, uniformes, leiaute do site e vinheta televisiva. Anteriormente à definição da marca, já estava sendo desenvolvida a ilustração da parede, cujos requisitos já haviam sido definidos

pelo cliente. Essa mesma ilustração deu origem ao jogo americano. Finalmente, confeccionou-se o manual da marca para ser entregue ao cliente. 


\section{Résumé}

Le but de ce travail est de développer l'Identité Visuelle du café Ovelha Negra. Pour atteindre ce but il a fallu faire, d'abord, une recherche sur les cafés et ses marques. Le résultat de la recherche nous a permis de conclure qu'il existe de nombreux cafés avec ce même nom partout dans le monde. Dès ce moment, on a fait une analyse dátaillée des marques de ces cafés et d'autres compositions visuelles portant le nom Ovelha Negra. En parallèle, on a fait une recherche avec le public-cible dans les cafés de Brasília. On a analysé, en même temps, la décoration des cafés choisis, selon le concept défini pour le café, par le client. Une fois accomplie l'étape du récensement de données, on a avancé vers las création d'alternatives pour la marque, selon les conditions établies. Une fois définies les marques, les couleurs de l'identité et la tipographie qui seraient utilisées, on a commencé l'étape de création des produits demandés dans l'ordre suivant: carte corporative, sous-verre, carte (menu), uniforme, layout du site et vignette de télévision. Avant la définition de la marque, l'illustration du mur était déjà en développement, d'après les conditions établies par le client. Cette illustration là a été à l'origine des sous-assiettes. Aprés, on a developé le manuel de la marque pour le client. 


\section{Lista de Figuras}

Figura 1 - Marca do bar catalão Ovella Negra 9

Figura 2 - Marca do bistrô canadense Mouton Noir 10

Figura 3 - Marca de um bistrô/ mercado/ padaria estadunidense 10

Figura 4 - Marca de pub da Inglaterra 11

Figura 5 - Marca de pub e restaurante dos Estados Unidos 11

Figura 6 - Marca de bistrô dos Estados Unidos $\quad 12$

Figura 7 - Tabela dos conteúdos dos sites 13

Figura 8 - Marcas de outros grupos ou empresas chamados Ovelha Negra 14

$\begin{array}{ll}\text { Figura } 9 \text { - Outras representações de ovelhas negras } & 14\end{array}$

Figura 10 - Vista exterior do bar Bendito Suco 15

Figura 11 - Mesa e cadeiras no Bendito Suco 16

Figura 12 - Espaço externo com decoração do Bendito Suco 16

$\begin{array}{ll}\text { Figura } 13 \text { - Espaço interno do bistrô Rayuela } & 17\end{array}$

Figura 14 - Gráfico da pergunta 1 da entrevista com público-alvo 19

Figura 15 - Gráfico das perguntas 2 e 3 da entrevista com público-alvo 20

Figura 16 - Gráfico da pergunta 4 da entrevista com público-alvo 20

Figura 17 - Gráfico da pergunta 5 da entrevista com público-alvo 21

Figura 18 - Gráfico da pergunta 6 da entrevista com público-alvo 21

Figura 19 - Gráfico da pergunta 7 da entrevista com público-alvo 22

Figura 20 - Gráfico da pergunta 8 da entrevista com público-alvo 22

Figura 21 - Gráfico da pergunta 9 da entrevista com público-alvo 23

Figura 22 - Gráfico da primeira pergunta feita sobre diferenças 23

Figura 23 - Gráfico da segunda pergunta feita sobre diferenças $\quad 24$

Figura 24 - Início da ilustração da parede $\quad 27$

Figura 25 - Metade do processo de geração da ilustração 27

Figura 26 - Ilustração final 28

Figura 27 - Primeiras alternativas de marca 29

$\begin{array}{ll}\text { Figura } 28 \text { - Segunda geração de alternativas de marca } & 29\end{array}$

Figura 29 - Alternativa com linhas e em negativo 30

Figura 30 - Marca utilizando a sigla de Bar Ovelha Negra (B.O.N.) e o nome $\quad 30$

Figura 31 - Marca em formato de brasão utilizando a sigla sem o nome completo 31

Figura 32 - Marca sem a sigla usando também a caneca de cerveja 32

Figura 33 - Quarta marca da geração de alternativa 32

Figura 34 - Marca sem elementos representativos 33

Figura 35 - Alternativa de marca com ovelha mais estilizada 33

Figura 36 - Marcas utilizando a ovelha mais arredondada 34

Figura 37 - Marca utilizando uma ovelha ainda mais estilizada 34

Figura 38 - Marca utilizando a mesma ovelha e uma tipografia mais trabalhada 35

Figura 39 - Mesma marca com a adição dos olhos $\quad 35$

Figura 40 - Marca com idéia mais agressiva 36

Figura 41 - Versão estilizada da marca anterior $\quad 37$

Figura 42 - Versão com mesma tipografia e ovelha por inteiro 37

Figura 43 - Versão híbrida misturando opções 38

Figura 44 - Versão com a ovelha arredondada e o sorriso maior 38 
Figura 45 - Versão final para ser utilizada em fundo branco e fundos claros 39

Figura 46 - Versão final para utilização em fundo preto e fundos escuros 39

Figura 47 - Cartão corporativo da empresa 40

Figura 48 - Porta-copo de cerveja $\quad 42$

Figura 49 - Frente do Cardápio $\quad 43$

Figura 50 - Verso do cardápio $\quad 44$

Figura 51 - Uniformes escolhidos $\quad 45$

Figura 52 - Hierarquia do conteúdo do site 46

Figura 53 - Simulação no site no navegador $\quad 47$

Figura 54 - Página inicial do site e link História do Bar 48

Figura 55 - Página do cardápio do bar $\quad 49$

Figura 56 - Página de fotos do bar $\quad 50$

Figura 57 - Loja virtual do bar $\quad 51$

Figura 58 - Marca final $\quad 54$

Figura 59 - Cartão final $\quad 54$

Figura 60 - Frente e verso da versão final do cardápio $\quad 55$

Figura 61 - Porta-copos versão final 56

Figura 62 - Uniformes versão final $\quad 57$

Figura 63 - Simulação de fachada $\quad 57$

Figura 64 - Ilustração final para jogo americano e parede do bar 58 


\section{1 - Introdução}

A principal demanda com relação à concepção da marca Bar Ovelha Negra é a resolução do dilema quanto à forma como ele foi batizado. De fato, a imagem de uma ovelha negra poderia transmitir a idéia equivocada de tratar-se de um estabelecimento para pessoas muito diferentes, excluídas, ou de algum nicho muito específico como motoqueiros, jovens rebeldes ou algo do tipo. O que os idealizadores do bar pretenderam com esse nome foi, por outro lado, ter uma marca de nome forte, que fosse de fácil memorização e que transmitisse o peso que a marca tentará alcançar na mente dos seus clientes.

Foi dado início então a uma série de discussões que tiveram como objetivo a clara definição dos limites e das abrangências do conceito Ovelha Negra. A primeira questão discutida foi uma forma de sanar a possível rejeição que o nome do bar poderia ter junto ao público. Para resolver essa questão, chegou-se à conclusão de que a marca não poderia de forma alguma reforçar essa noção de sectarismo, exclusão, rebeldia ou tristeza. As cores, as formas e a feição da ovelha e os demais elementos deveriam, para tanto, ser leves e transmitir sensações de alegria e bem-estar. Cores escuras e formas muito pesadas não deveriam ser utilizadas. Outro ponto importante da discussão foi a definição de que a marca deveria ter um caráter bastante convidativo. Um dos principais planos dos donos do bar é de transformar a marca em uma paixão para os clientes, assim como acontece com a chopperia Pingüim e outras marcas de sucesso.

O presente trabalho tem como objetivo o desenvolvimento da Identidade Visual completa do bar Ovelha Negra. Essa identidade abrange os seguintes meios gráficos: marca, cartão corporativo, fachada, uniformes, cardápios, pintura interna do bar, vinheta televisiva e leiaute do site. Além dos aspectos gráficos, faz parte do projeto a elaboração de outros aspectos intrínsecos a essas demandas. Entre eles estão: hierarquia e organização do conteúdo do site, definição do conceito da idéia de ovelha negra, concepção da fachada em 3d do bar, definição da estrutura do cardápio.

O projeto passou por todas as etapas estudadas durante o curso. Primeiro, fez-se um estudo detalhado das demandas e dos objetivos do projeto. Em seguida, foram levantadas as 
informações sobre projetos parecidos, fontes de referência (bibliográficas ou de outros meios) e definiu-se uma metodologia. Para desenvolver esse projeto, especificamente, a etapa seguinte foi a pesquisa junto ao público-alvo da aceitação do nome do bar e a forma como o público concebia o seu conceito, de forma a confirmar alguns requisitos levantados. Passou-se então, para a geração de alternativas, levando como base os dados já coletados e os preceitos do design gráfico.

No mercado de bares de Brasília é raro encontrar estabelecimentos com marcas bem desenvolvidas, e mais raro ainda é encontrar algum que tenha um sistema de Identidade Visual estabelecido e respeitado. Diante disso, o presente trabalho torna-se extremamente importante, no sentido de expandir as fronteiras dos tipos de empresas que investem na qualidade de suas marcas. Mesmo que o objeto de consumo de um bar não seja levado para casa pelo comprador, o vínculo afetivo criado pelos clientes com o(s) bar(es) de sua preferência já justifica um desenvolvimento mais cuidadoso da sua identidade. Sendo a proposta do demandante do projeto bastante inovadora, há a necessidade de se criar uma marca que contemple também essa proposta.

Como público ideal do bar, definiu-se que seriam jovens e adultos, com idades entre 18 e 35 anos, das classes A e B, interessados em arte, cultura e gastronomia. O estudo do público-alvo constitui-se numa peça importante para o desenvolvimento do trabalho, pois possibilita o correto desenvolvimento da idéia que os idealizadores do bar desejam passar com o conceito de Ovelha Negra. 


\section{2 - Levantamento de Dados}

O primeiro levantamento feito foi uma pesquisa de representações de ovelhas negras. Primeiro foram analisadas as representações de bares que utilizam essa marca e o conteúdo dos seus sites. Em seguida, foram analisadas as marcas com ovelhas negras que não fossem de bares. Por último, pesquisaram-se as representações com ovelhas negras não usadas como marcas, mas simplesmente para ilustrar algo: cartazes, ilustrações, etc.

\section{1 - Análise de Similares}

Aqui foram analisadas marcas de bares, pubs e bistrôs chamados "Ovelha Negra". No total foram escolhidos seis desses estabelecimentos. Cada marca foi analisada de forma a identificar pontos comuns e discordâncias entre elas, com o objetivo de formular uma marca que não repita os mesmo erros das analisadas e possa, de alguma forma, incorporar seus pontos fortes.

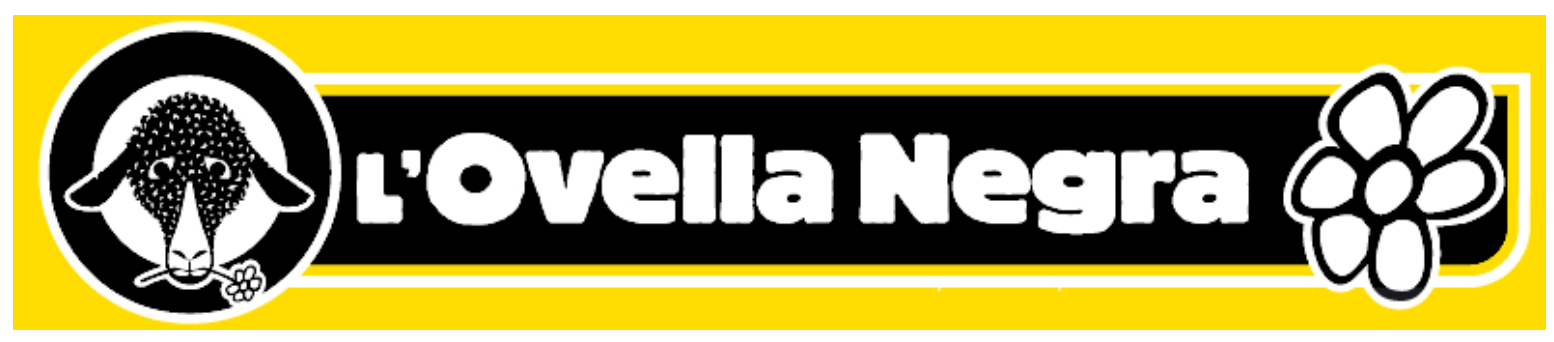

Figura 1- Marca do bar catalão Ovella Negra

O bar catalão utiliza as cores preta e amarela, o que é muito interessante pois remete ao principal produto do bar, a cerveja, e obtém ainda um contraste que realça a marca. A ilustração da ovelha triste remete, no entanto, a um sentimento oposto àquele que os clientes procuram num bar. Outro ponto fraco é também referente à ilustração. Por ela ser pouco simplificada, com muitas linhas e detalhes pequenos, sua utilização fica prejudicada nas reduções. 


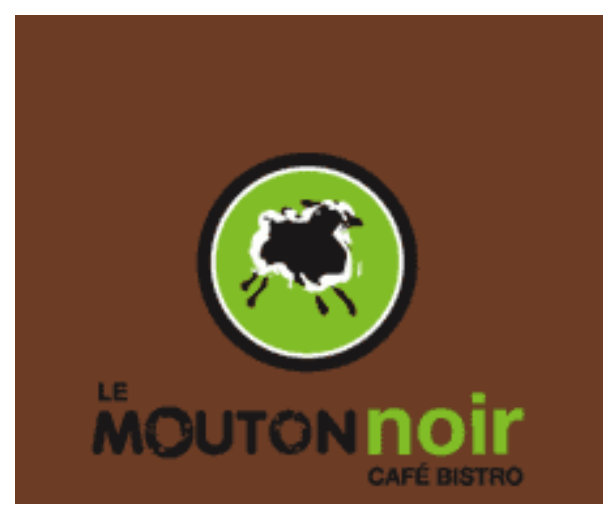

Figura 2- Marca do bistrô canadense Mouton Noir

Nessa marca, ao contrário da primeira, há uma maior estilização da ovelha, o que é positivo. A tipografia utilizada e a mudança de cores tornaram a marca mais leve também. O seu ponto fraco é a falta de interação entre os elementos. O elemento formado pela ovelha contida no círculo não interage de forma plena com o nome embaixo. O espaço entre ele é grande demais e o fato do desenho ser um círculo dificulta essa interação.

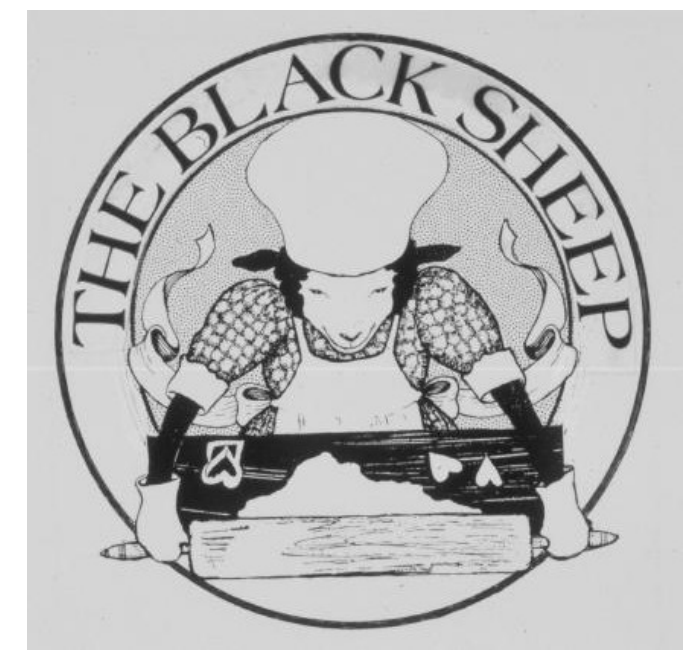

Figura 3- Marca de um bistrô/ mercado/ padaria estadunidense

Nessa marca há uma ilustração bastante complexa de uma ovelha preparando uma massa. A ilustração é satisfatória levando-se em consideração que tratar também de uma padaria. A pobreza da gama de cores e a forma como o nome está colocado na marca prejudicam seu entendimento. Como na primeira marca analisada, a relativamente alta complexidade da marca dificultam sua utilização em reduções. 


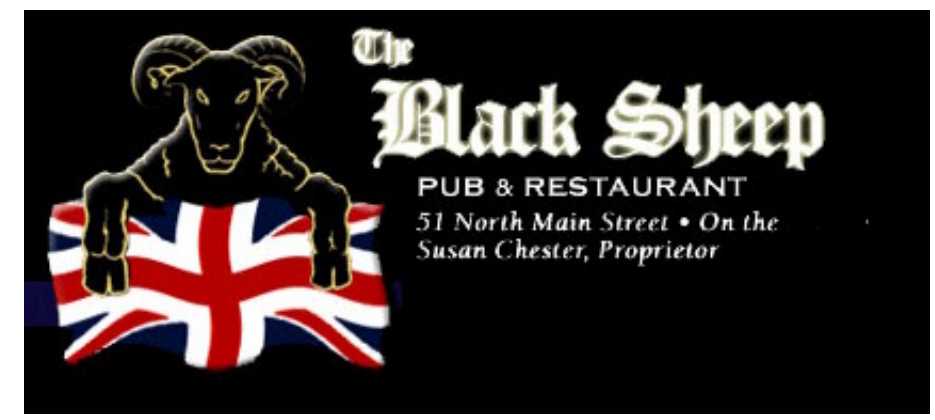

Figura 4 - Marca de pub da Inglaterra

Marca pouco coesa e com detalhes em demasia. A tipografia utilizada parece pouco pertinente por se tratar de um bar. Ela talvez fosse mais convenientemente utilizável para a marca de um grupo de motociclistas.

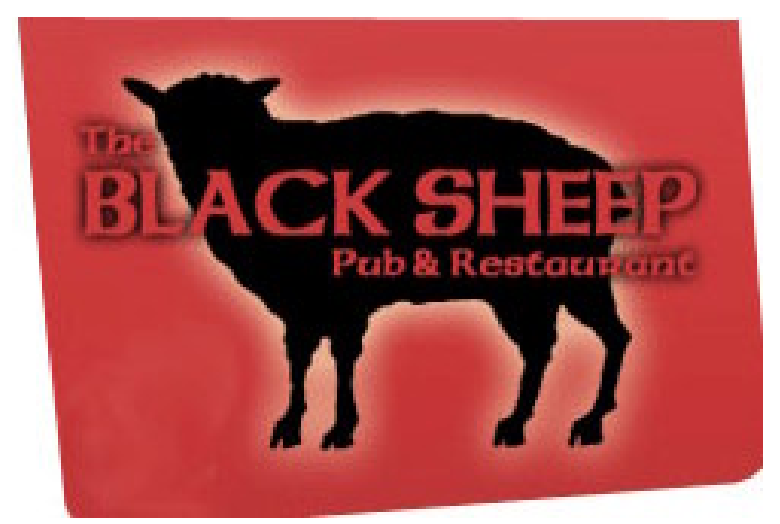

Figura 5 - Marca de pub e restaurante dos Estados Unidos

Marca pouco coesa também. $\mathrm{O}$ fato de ter um fundo necessariamente vermelho dificulta sua utilização. A representação da ovelha, apesar de estar em negativo, o que facilitaria sua utilização, não foi completamente simplificada e ainda contém arestas que seriam desfavoráveis a uma ampla utilização da marca. 


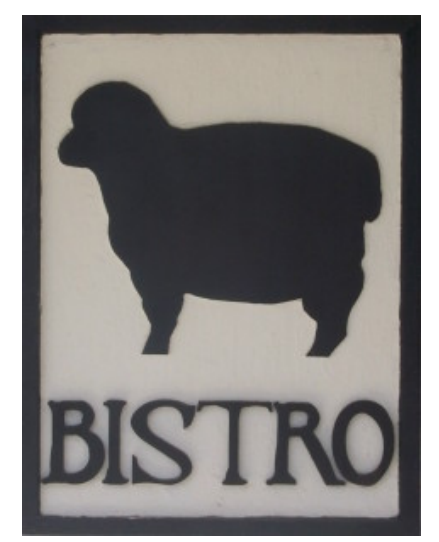

Figura 6 - Marca de bistrô dos Estados Unidos

Marca bastante eficiente. A representação simples e monocromática facilita sua utilização. A tipografia dotada também é bastante pertinente a um bistrô. Falta porém alguma maior interação entre os elementos da marca também. Também poderia ser criticada a ausência de cores secundárias que pudessem ajudar a compor a Identidade Visual do bistrô.

\section{2 - Conclusões}

As marcas avaliadas de forma mais positiva segundo os critérios estabelecidos foram aquelas que tinham como símbolo ovelhas mais simples. Com relação ao emprego de cores, aquelas que utilizaram um menor número delas e com menos nuanças foram as mais eficazes.

\section{3 - Análise do Conteúdo dos Sites}

Foram analisados os conteúdos de cada site de bar pesquisados afim de levantar as especificidades desse tipo de site para nortear o desenvolvimento do site do bar projetado. As informações completas com detalhes de cada elemento encontrado nos sites encontramse no apêndice do relatório. Segue no entanto a tabela com o resumo das informações encontradas em cada site. 

A - Le Mouton Noir Café Bistrô (Canadá)
B - The Black Sheep Pub (EUA)
C - The Black Sheep Pub (Inglaterra)
D - The Black Sheep (EUA)
E - Black Sheep Bistrô (EUA)
F - Bar do Calaf (Brasil)
G - Bar do Juarez (Brasil)
H - Bar Pingüim (Brasil)
I - Ovella Negra (Espanha)

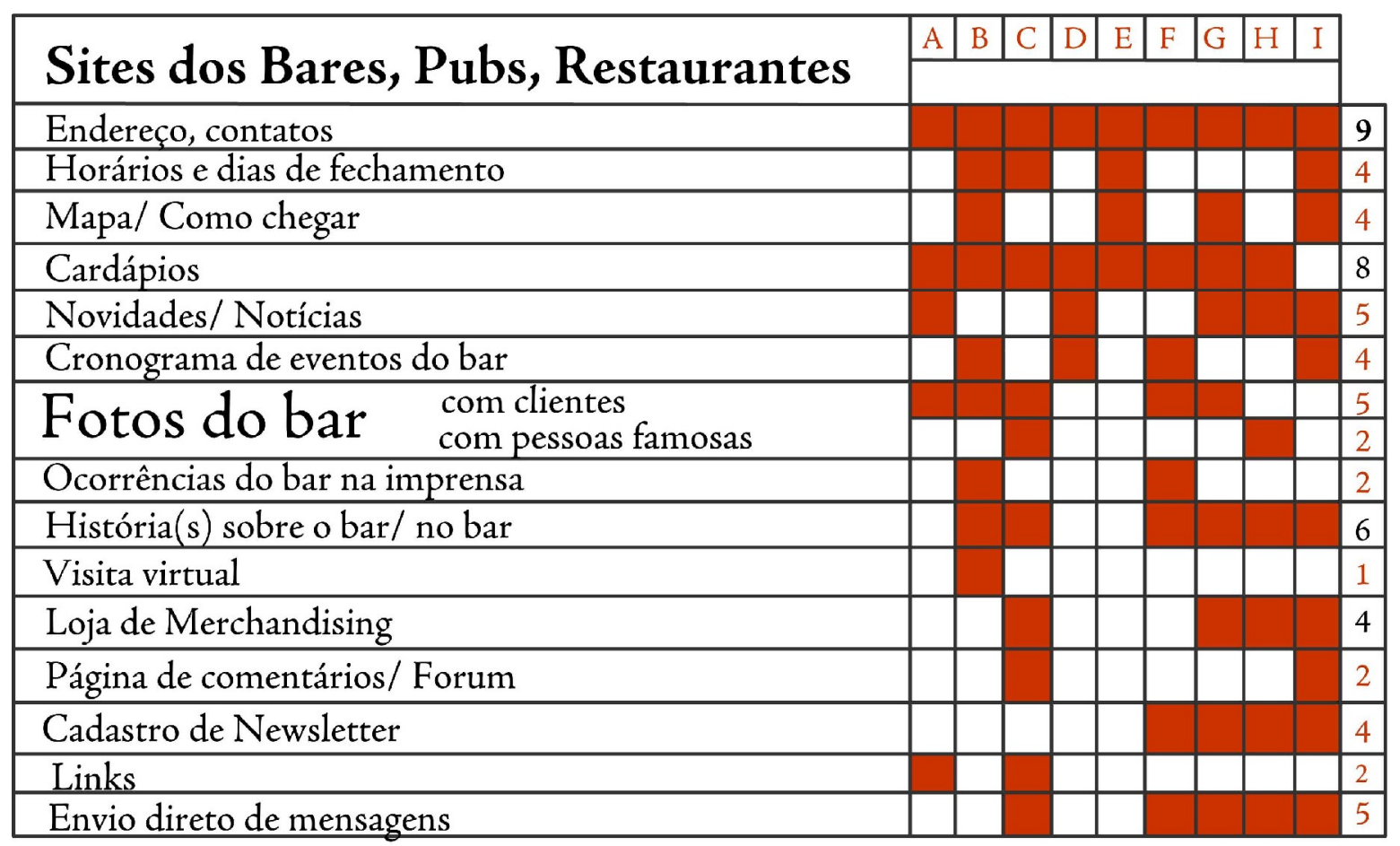

Figura 7 - Tabela dos conteúdos dos sites

Com esse resultado, foram escolhidos para compor o layout inicial do site os quatro itens com maior número de ocorrências que são: endereço e contatos; cardápios; fotos do bar e clientes e histórias do bar. Além desses quatro itens foi adicionada, a pedido do demandante, uma loja virtual. 


\section{4 - Marcas de outros lugares chamados Ovelha Negra}

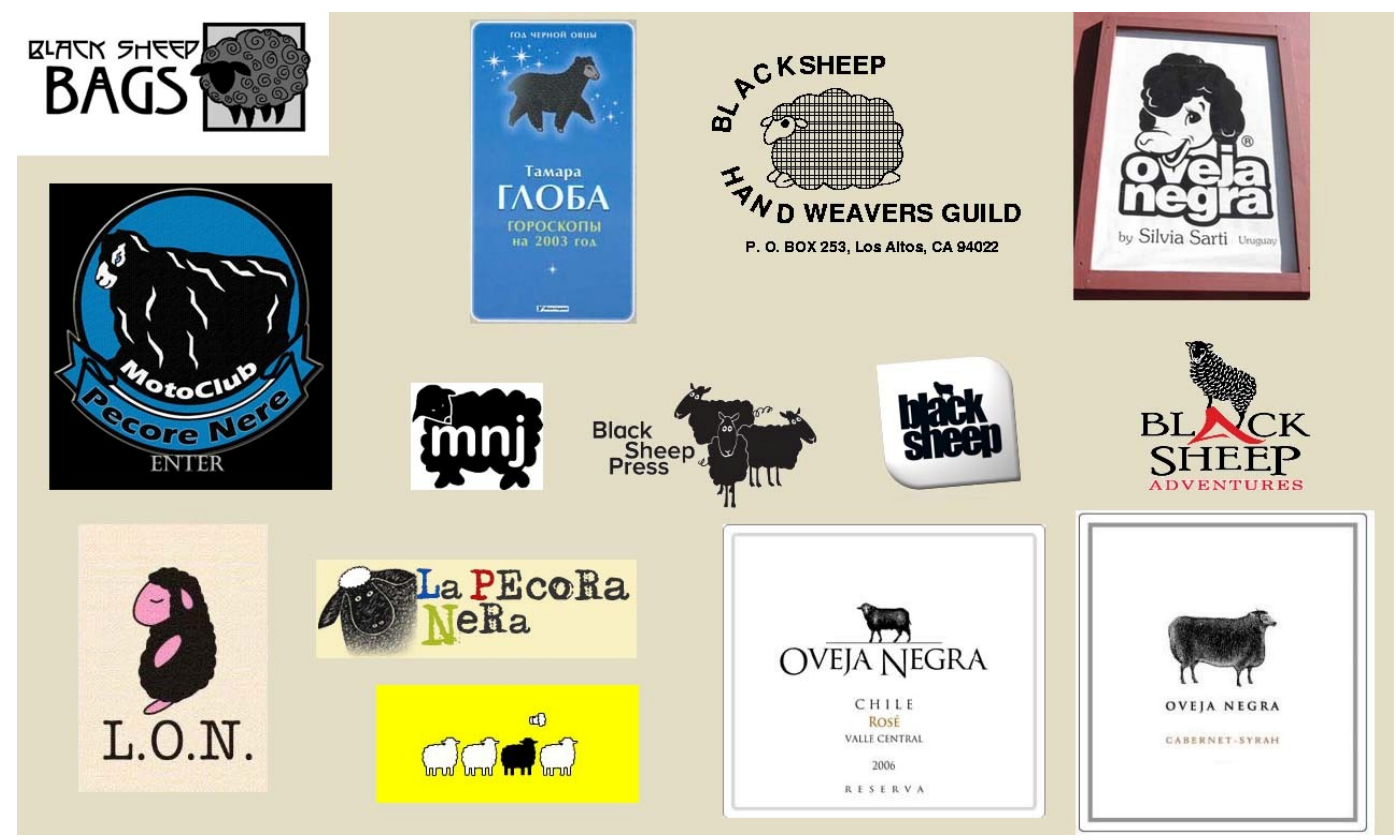

Figura 8 - Marcas de outros grupos ou empresas chamados Ovelha Negra

Nesta etapa foram observados os estilos e as formas de representá-las. Em algumas ovelhas, por exemplo, não há uma representação muito detalhada dos "cachinhos", ficando esta restrita apenas ao contorno da ovelha. Isso no entanto não acarretou em perda de significação. Outro ponto interessante observado foi o fato de a maioria das ovelhas não terem rabo, o que facilita sua estilização.

\section{5 - Outras representações com ovelhas negras}
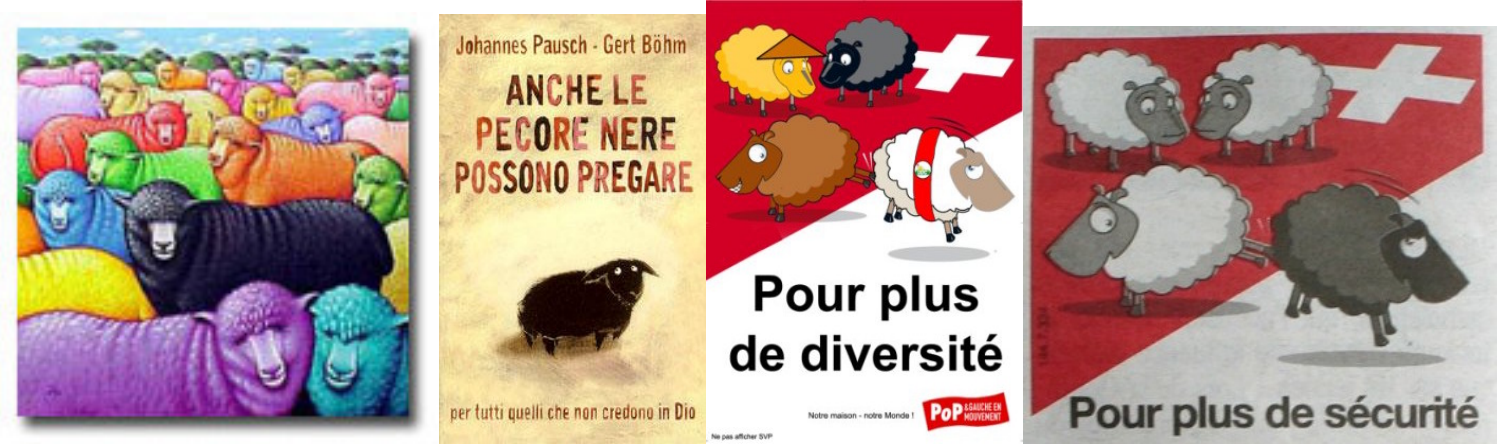

Figura 9 - Outras representações de ovelhas negras 
Nessas representações de ovelhas negras percebe-se uma inovação interessante. Há nos casos da primeira e da terceira ilustração, a relativização do conceito de "ovelha negra". Neles, as ovelhas diferentes não são necessariamente negras, mas sim coloridas. Isso abriria um precedente interessante para a criação do conceito da marca, que apesar de não ter sido utilizado, confirmou a idéia de que o público não via as ovelhas negras como necessariamente inferiores.

\section{6 - Similares de Brasília}

Nessa etapa do projeto foram estudados estabelecimentos de Brasília que tivessem uma proposta parecida com a do Bar Ovelha Negra. Ou seja, bares, bistrôs, pubs e lanchonetes que primassem pelo visual arrojado e que quisessem conquistar uma parcela jovem, aculturada e abastada do público de Brasília. Foram tiradas, então, fotos das decorações desses lugares, para serem utilizadas como referência.

\section{Bendito Suco}

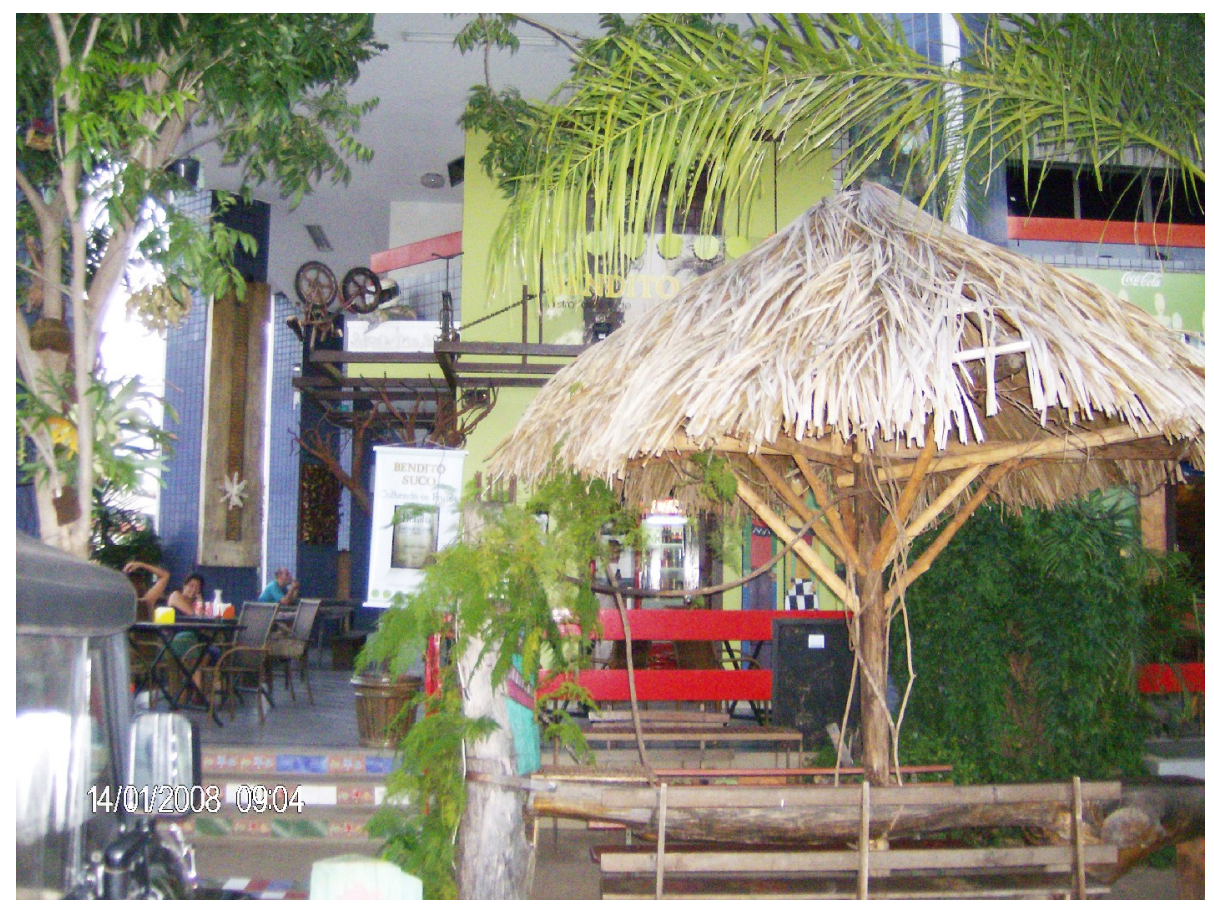

Figura 10 - Vista exterior do Bendito Suco 
Na parte de fora do bendito Suco encontram-se mesas e bancos de madeira feitos artesanalmente. Há inúmeras obras de arte entre quadros e esculturas espalhados pelo ambiente. Uma profusão magnífica de cores atrai a atenção de quem passa em frente ao estabelecimento, misturando construções humanas com árvores e arbustos ornamentais.

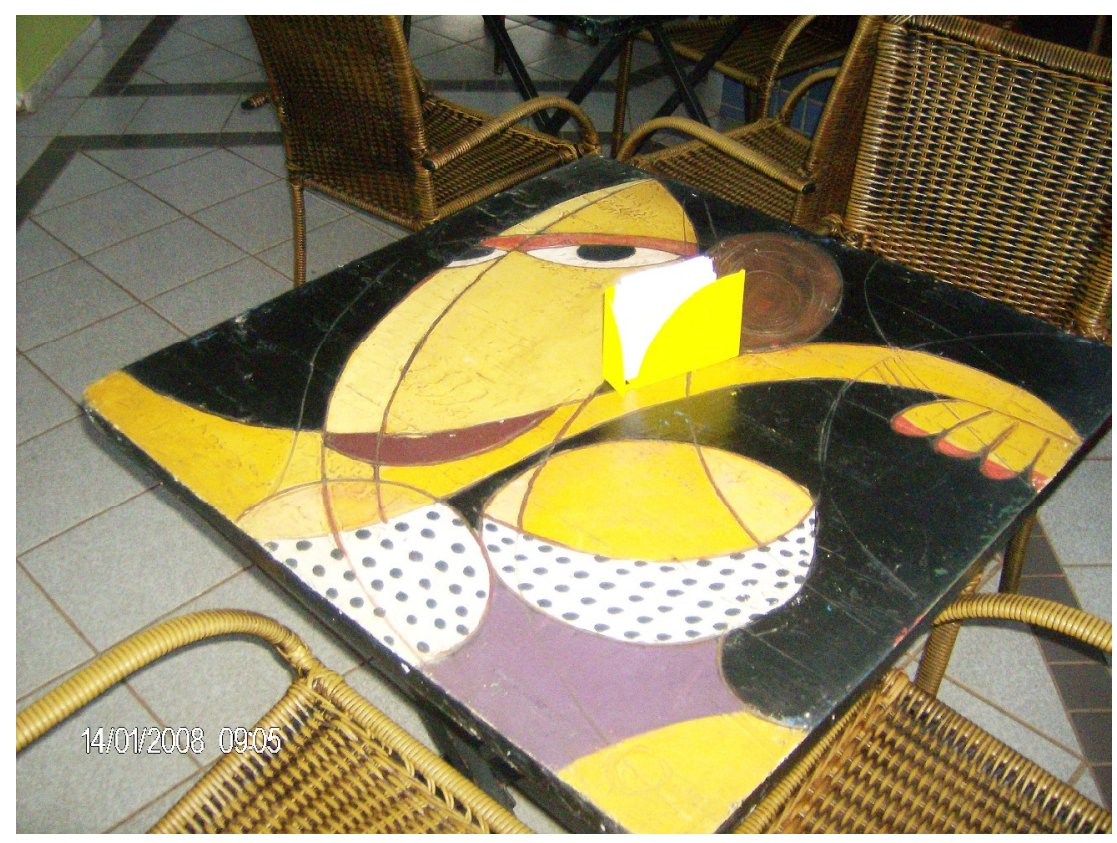

Figura 11 - Mesa e cadeiras no Bendito Suco

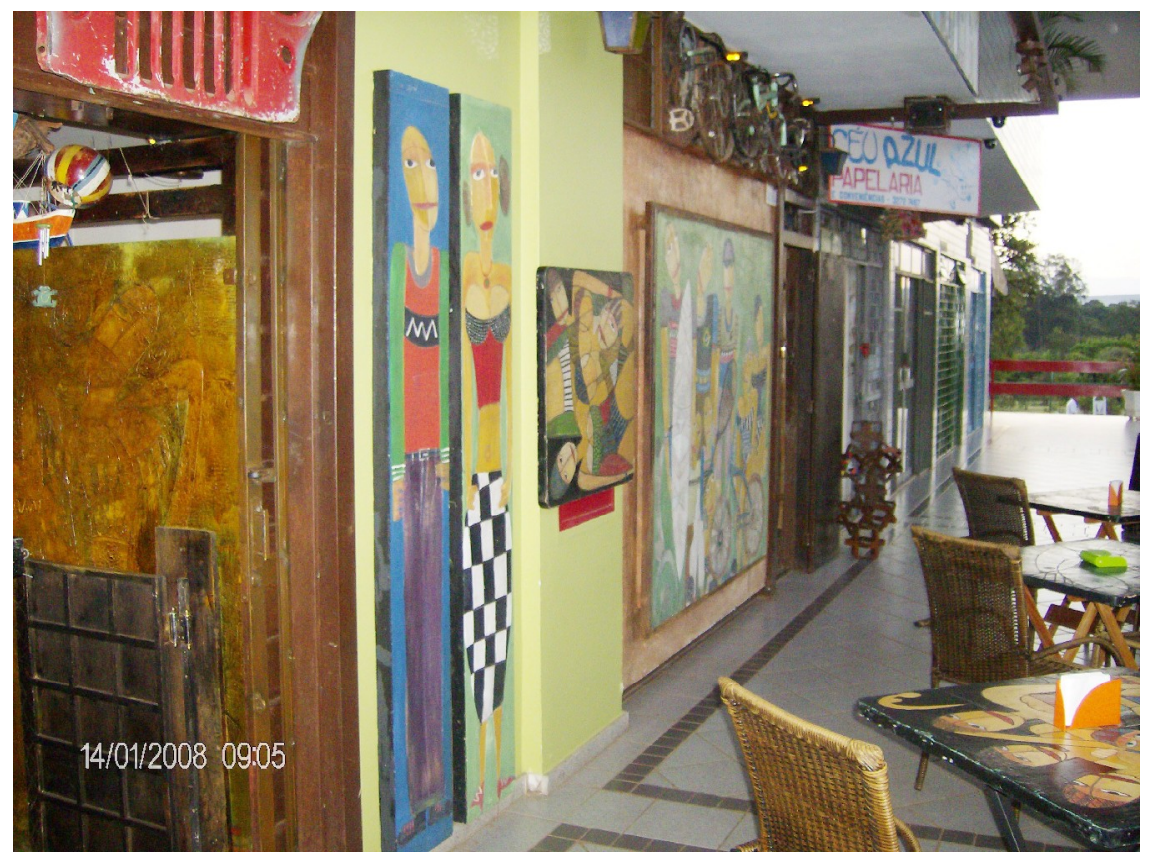

Figura 12 - Espaço externo com decoração do Bendito Suco 


\section{Rayuela}

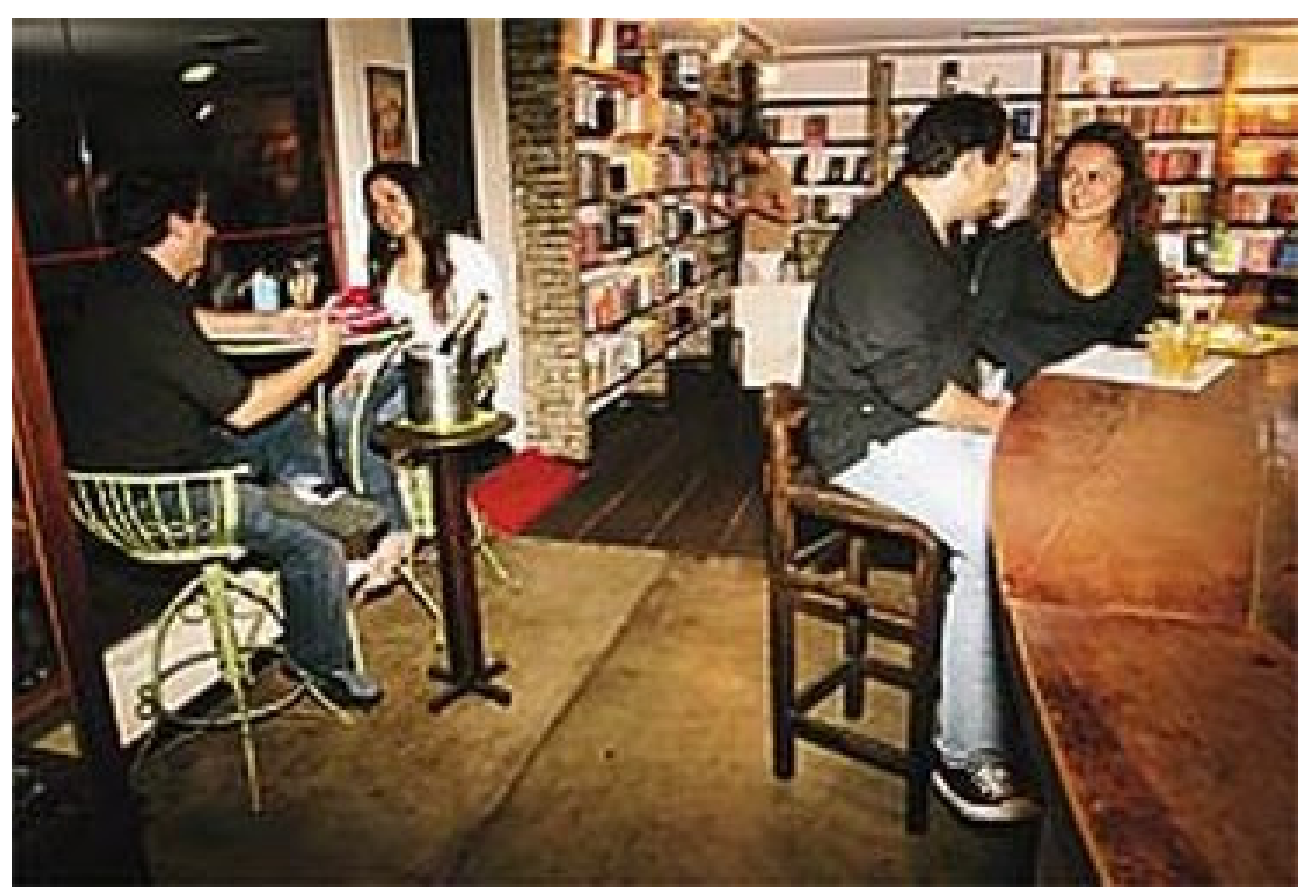

Figura 13 - Espaço interno do bistrô Rayuela

No bistrô Rayuela o ponto forte é o aspecto cultural e literário que passa o lugar. Em seu interior situam-se estantes de livros e aconchegantes sofás e poltronas que convidam o cliente a uma leitura despretensiosa. As mesas e cadeiras, apesar de industrializadas, passam a mesma idéia de cultura e sofisticação, com designs mais naturalistas.

\section{7 - Pesquisa com Público-Alvo}

Nessa etapa do projeto, foi feita uma série de entrevistas com clientes de bares conhecidos de Brasília. O objetivo dessa pesquisa foi elucidar questões a respeito do perfil desse público e da aceitação do conceito de ovelha negra como nome do bar. A pesquisa foi realizada em diferentes bares de Brasília. Os critérios para a escolha dos bares não foi simplesmente contemplar os bares com perfil similar ao do bar do projeto, mas sim perguntar ao grande público de bares, que costuma freqüentar os bares da pesquisa. Dessa forma, tentou-se descobrir o que esses clientes pensariam de um bar que misturasse esses dois conceitos de bar alternativo e popular. 


\subsection{1 - Perguntas da Entrevista}

1 - Com que freqüência você costuma ir a esse bar?

2 - O que o faz vir aqui com freqüência?

3- O que você aprecia no bar?

4-O que você mais aprecia nesse bar?

5 - O que você não gosta com relação ao bar?

6 - Se você pudesse mudar alguma coisa no bar, o que mudaria?

7 - Você acha que um bar pode cobrar mais um visual arrojado?

8 - O que você acha que o site de um bar deveria oferecer?

9 - O que representa para você uma ovelha negra?

10 - Você acha que cada um é diferente à sua maneira?

Você acha bom ou ruim ser diferente? 


\subsection{2 - Resultados}

As respostas dos entrevistados seguiram mais ou menos uma tendência e demonstraram a homogeneidade do público dos bares. Aquelas informações que não puderem ser utilizadas para o presente trabalho poderão dar forma a estratégias de marketing e campanhas publicitárias.

Seguem os resultados em forma de gráfico:

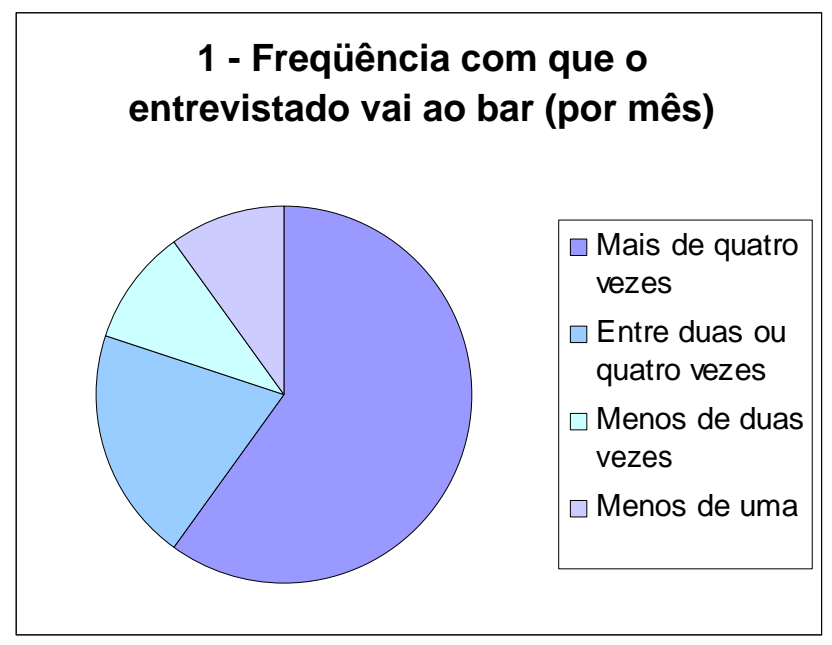

Figura 14 - Gráfico da pergunta 1 da entrevista com público-alvo

Percebe-se com o gráfico anterior que o público de Brasília freqüenta bastante os bares. Isso pode ser utilizado para, por exemplo, definir programas em que o cliente recebe um cartão e a cada cerveja comprada ele recebe um carimbo ou um adesivo e após acumular uma quantidade tal desses itens de controle o cliente poderia trocá-los por mais do produto. 


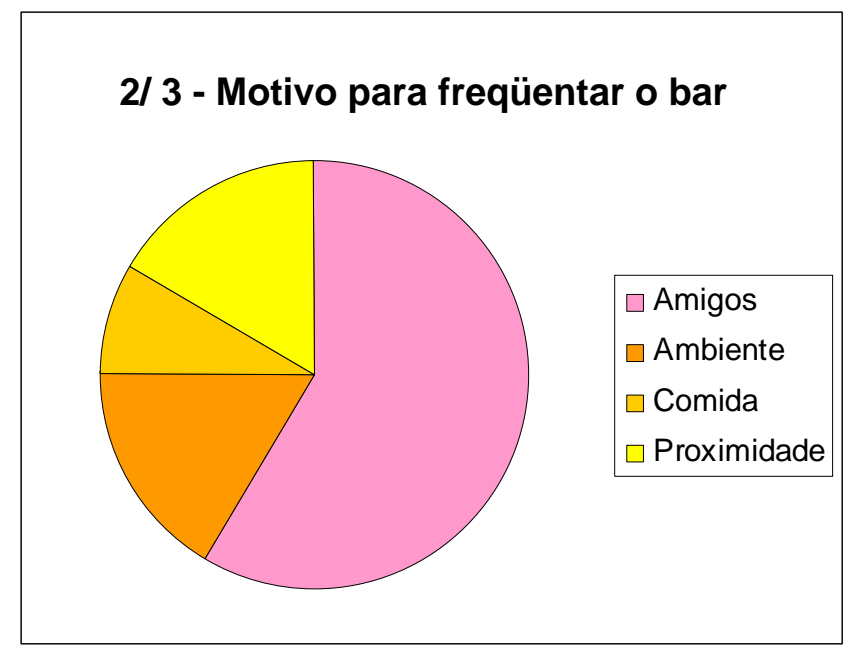

Figura 15 - Gráfico das perguntas 2 e 3 da entrevista com público-alvo

Com esse gráfico tiram-se as conclusões de que o principal motivo para que esse público geral frequiente os bares é a possibilidade de encontrar amigos e pessoas conhecidas o que vai ao encontro da proposta do idealizador de implementar políticas de fidelização junto ao público, como o convite a amigos, que poderia ser trocado por descontos.

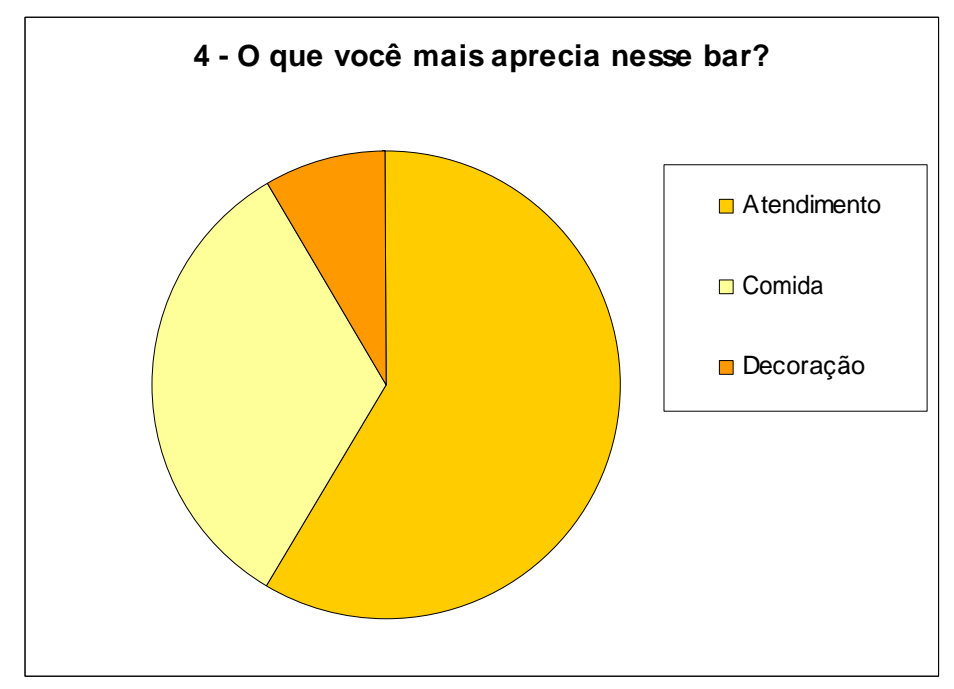

Figura 16- Gráfico da pergunta 4 da entrevista com público-alvo

Com o resultado da pergunta anterior, percebe-se que o atendimento é importantíssimo para a satisfação do cliente. Isso poderá ser utilizado na elaboração do 
cardápio. Quanto mais rápido for o acesso à informação no cardápio, mais fácil será sua comunicação ao garçom que, consequentemente, fará um melhor atendimento.

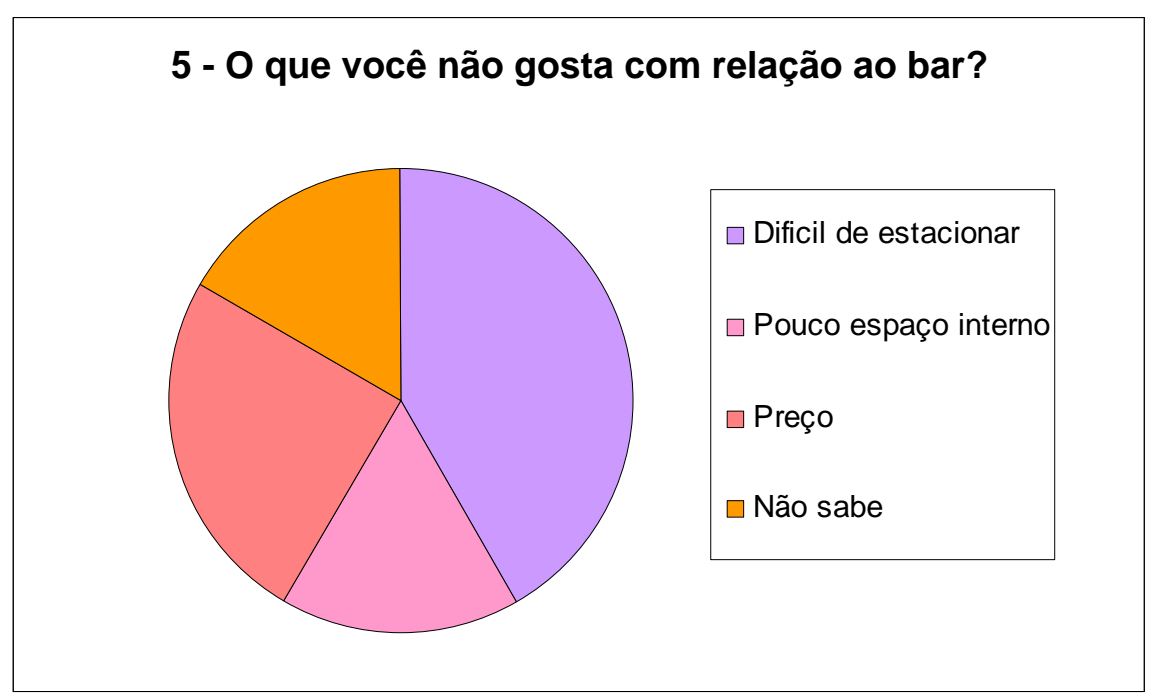

Figura 17- Gráfico da pergunta 5 da entrevista com público-alvo

Percebe-se através desse gráfico que a escolha da localização do bar deverá ser feita com cuidado para evitar esses lugares que têm poucas vagas.

\section{6 - Se você pudesse mudar alguma coisa no bar, o que mudaria?}

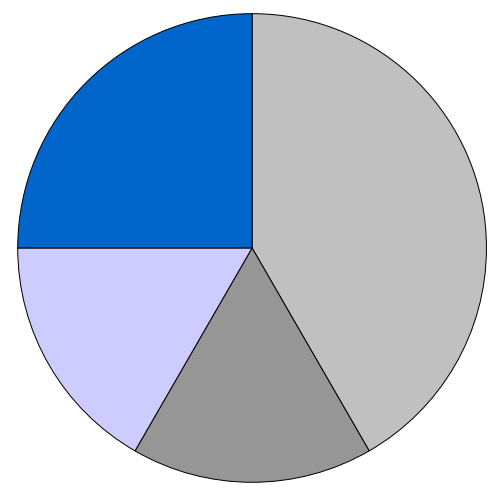

$$
\begin{aligned}
& \square \text { Nada } \\
& \square \text { Comida de graça } \\
& \square \text { Televisão } \\
& \square \text { Não Sabe }
\end{aligned}
$$

Figura 18- Gráfico da pergunta 6 da entrevista com público-alvo 
$\mathrm{O}$ fato de um quarto dos entrevistados ter respondido que forneceria comida de graça no bar talvez indique algo que possa ser explorado. Em alguns lugares há amendoim à vontade ou outras comidas servidas nas mesas periodicamente.

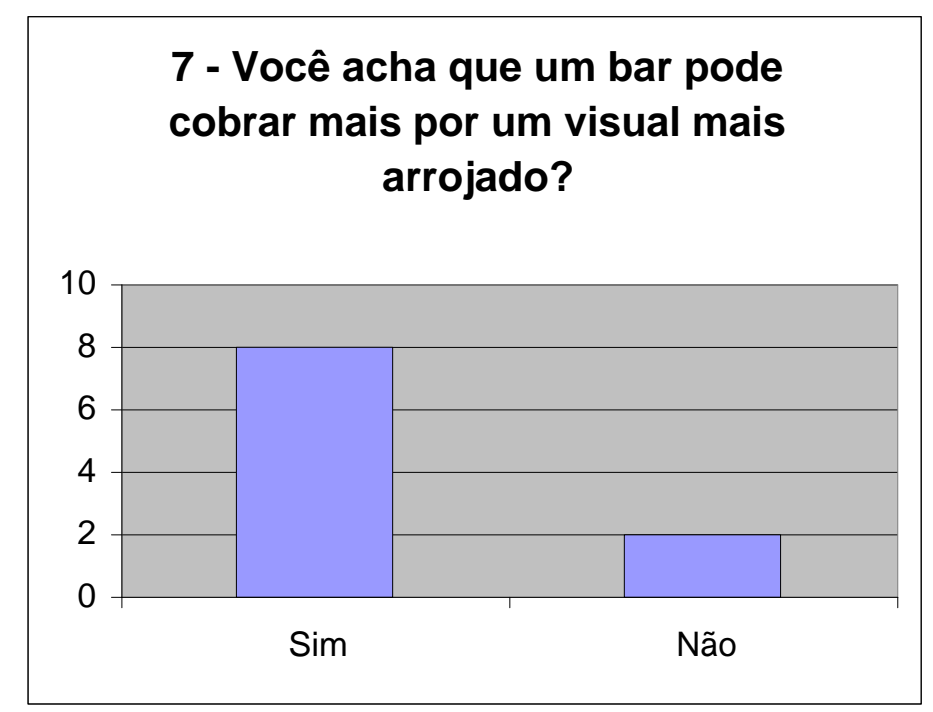

Figura 19 - Gráfico da pergunta 7 da entrevista com público-alvo

Com esse gráfico percebe-se que o público não é contra um investimento maior no aspecto gráfico do bar, com decorações, identidade visual, etc. Isso permite uma maior liberdade de criação e de planejamento de impressão e produção dos produtos.

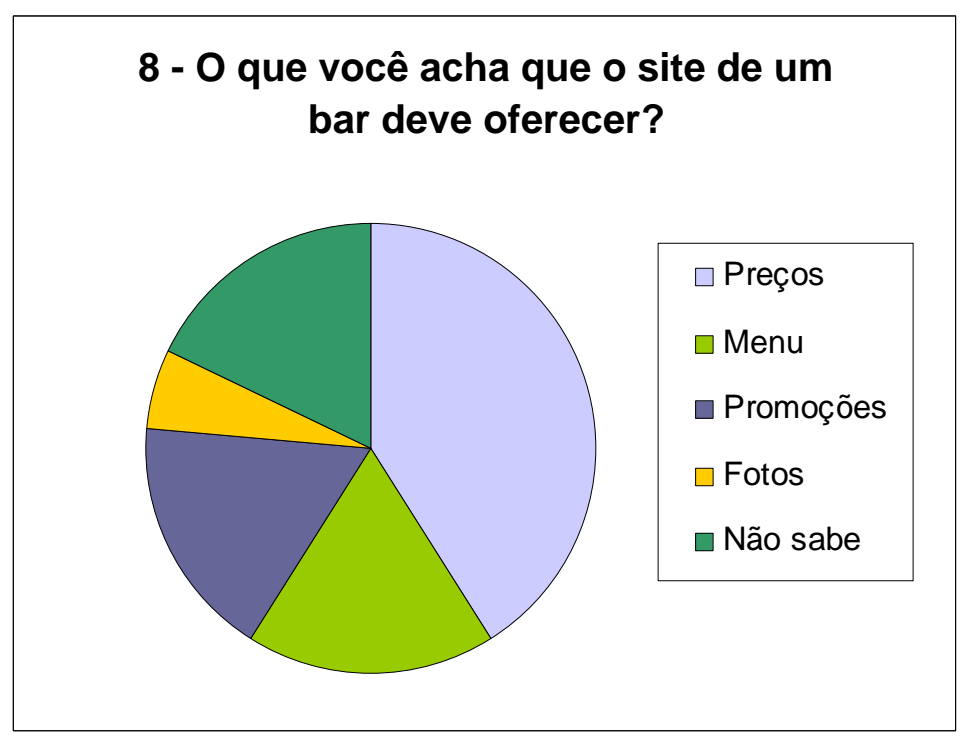

Figura 20- Gráfico da pergunta 8 da entrevista com público-alvo 
Confirmaram-se com o gráfico acima as expectativas já definidas com a análise de conteúdo dos sites de bares analisados.

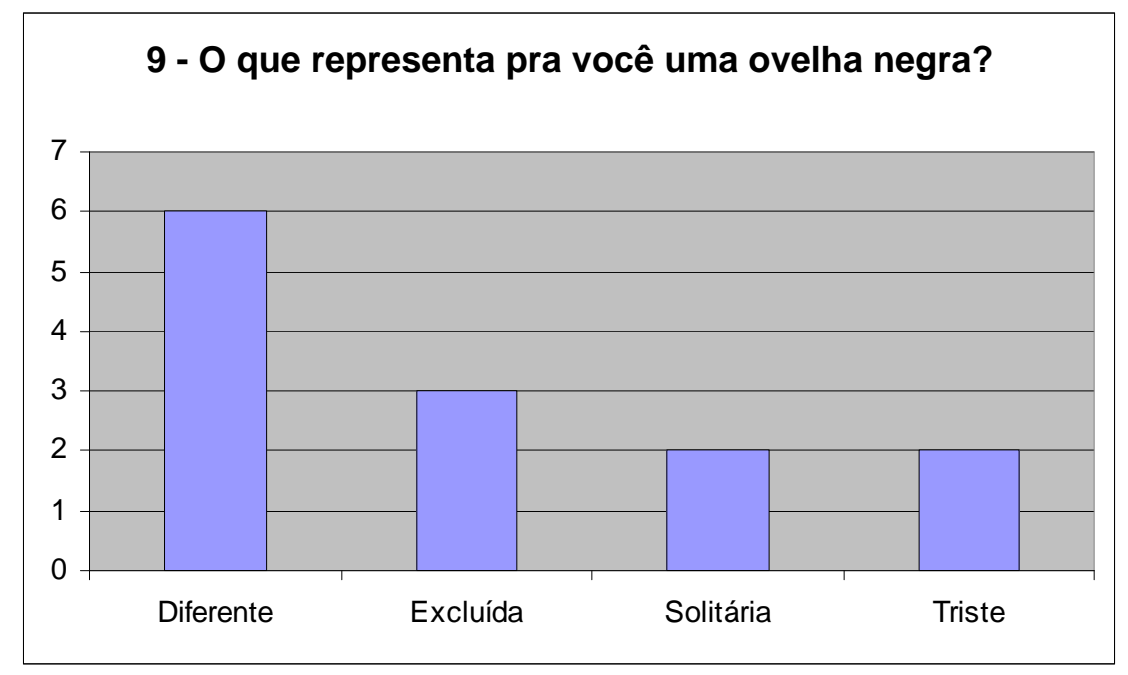

Figura 21- Gráfico da pergunta 9 da entrevista com público-alvo

Essas respostas demonstram que a visão das pessoas com relação a ovelhas negras não é tão marcada por pontos negativos. Prova que qualquer conceito pré-estabelecido na mente dos usuários não é tão forte a ponto de não poder ser revertida.

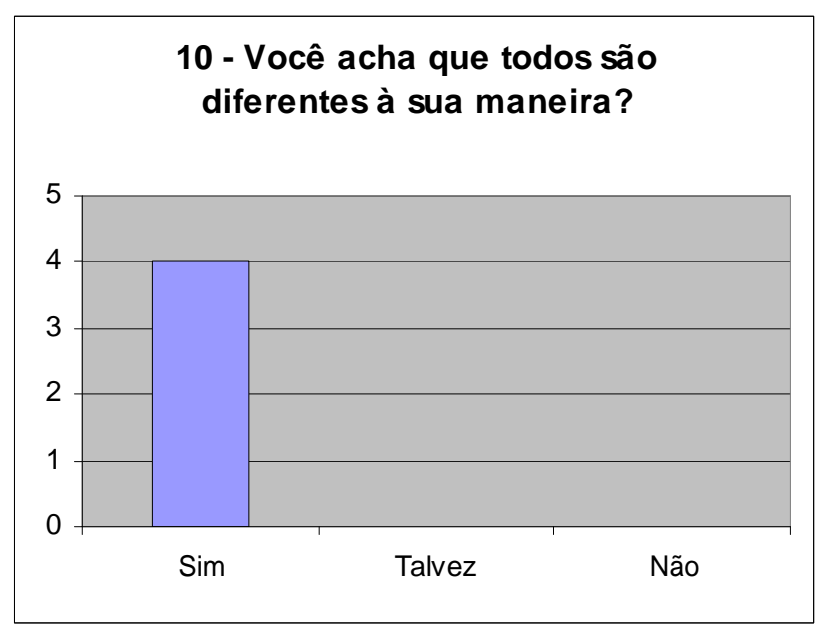

Figura 22 - Gráfico da primeira pergunta feita sobre diferenças 


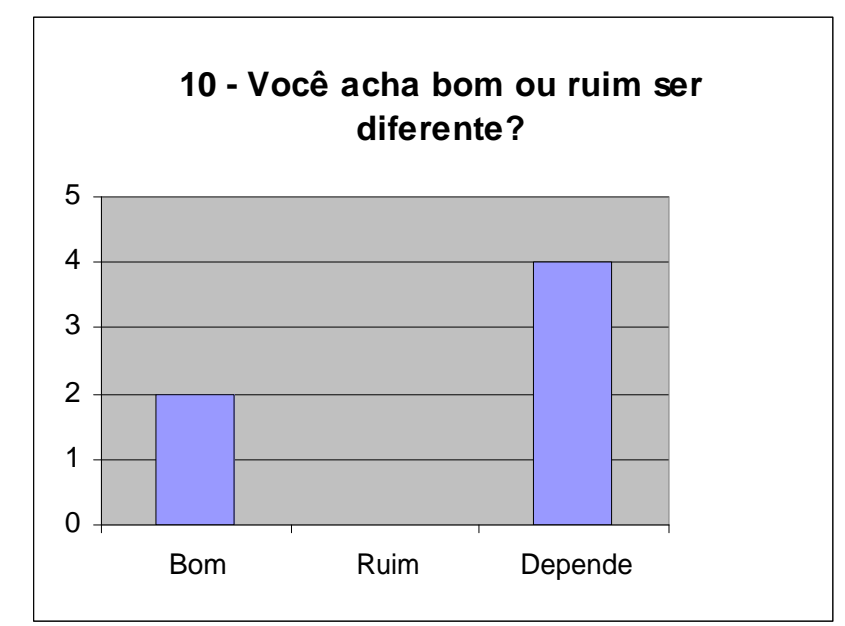

Figura 23 - Gráfico da segunda pergunta feita sobre diferenças

\subsection{3 - Conclusão da Pesquisa com Público-Alvo}

Percebe-se com essas respostas que o público-alvo se identifica também com as diferenças, não são preconceituosos e, por isso, receberiam bem até mesmo uma representação de uma ovelha negra sendo diferente das demais. De posse desses resultados, o dono do bar poderá traçar as estratégias de marketing e poderá definir que aspectos terão mais cuidados na escolha do local e na sua construção. Essa pesquisa mostra o quanto o público de Brasília gosta de tradição e quanto realmente contam os aspectos como bom atendimento e boa localização.

No tocante ao projeto de Identidade, foi possível definir alguns requisitos que poderão ajudar na elaboração da marca. São eles: fácil acesso à informação dos cardápios; possibilidade de um custo relativo alto; e símbolo da ovelha com feições positivas e/ ou amigáveis. 


\section{3 - Requisitos do Projeto}

Somando-se as informações recolhidas com a análise de marcas e ilustrações similares, a pesquisa com público-alvo e a pesquisa de conteúdo dos sites similares foi possível definir uma série de requisitos para a Identidade Visual como um todo e para cada produto demandado particularmente.

Os requisitos são:

- A marca deverá unir aspectos de sofisticação e jovialidade/ modernidade. Isso, no entanto, deverá ser feito de forma harmônica, respeitando preceitos estéticos e de design gráfico.

- A ovelha, se for utilizada como elemento para desenvolver a marca, deverá ser apresentada de forma positiva ao público. Sua aceitação deverá se dar por um sentimento de empatia e coleguismo, não de piedade e diferença. Ela poderá ou não ser estilizada, e poderá ou não ser negra.

- O cartão deverá mostrar as qualidades da marca do bar de uma forma eficaz para aqueles que ainda não o conhecem.

- A ilustração da parede deverá utilizar elementos da linguagem do grafite, tendo contornos forte e, caso tenha cores, estas deverão ser fortes e variadas.

- O cardápio deverá facilitar o manuseio pelo cliente e ter seus itens em fácil acesso para proporcionar um atendimento mais rápido e eficaz. Ele deverá também ter elementos que remetam à idéia de o bar ter uma cozinha com itens variados e bem produzidos.

- Os uniformes e porta-copos serão itens do bar que poderão também ser vendidos ou presenteados em promoções ou brinde para os clientes. Para isso, suas cores e seu formato deverão despertar o desejo do cliente em adquiri-los. Os uniformes deverão ter um corte moderno assim como suas cores. Os porta-copos deverão ser bem variados.

- O site do bar deverá ser prático e permitir acessos rápidos. Seu principal objetivo será apresentar o bar para aqueles que ainda não o conhecem. 


\section{4 - Geração de Alternativas}

Durante a geração de alternativas foram desenvolvidas mais de 20 (vinte) alternativas de marca. Para as ilustrações da parede foram feitos quase 30 (trinta) 
ilustrações avulsas, que juntas, formaram varas alternativas de composição. Na geração dos uniformes foram desenvolvidas 5 alternativas, cujas opções descartadas serão utilizadas para a loja como materiais de divulgação e promoção da marca. Foram feitas também 10 (dez) alternativas de bolachas de copo de cerveja que poderão ser utilizadas a gosto do demandante. No caso do cartão corporativo foram desenvolvidas 2 (duas) alternativas entre as quais uma foi descartada. No caso do cardápio e do leiaute do site as alternativas escolhidas foram as primeiras a ser desenvolvidas pois já havia uma idéia bem precisa de como seriam.

\section{1 - Ilustração da parede e do jogo americano}

A primeira alternativa de parede segue as referências do grupo c215. Trata-se de uma equipe de grafiteiros e ilustradores de Paris. A escolha desse grupo deve-se às formas orgânicas que eles utilizam e do estilo caótico que foram requisitos projetados para essa etapa do trabalho.

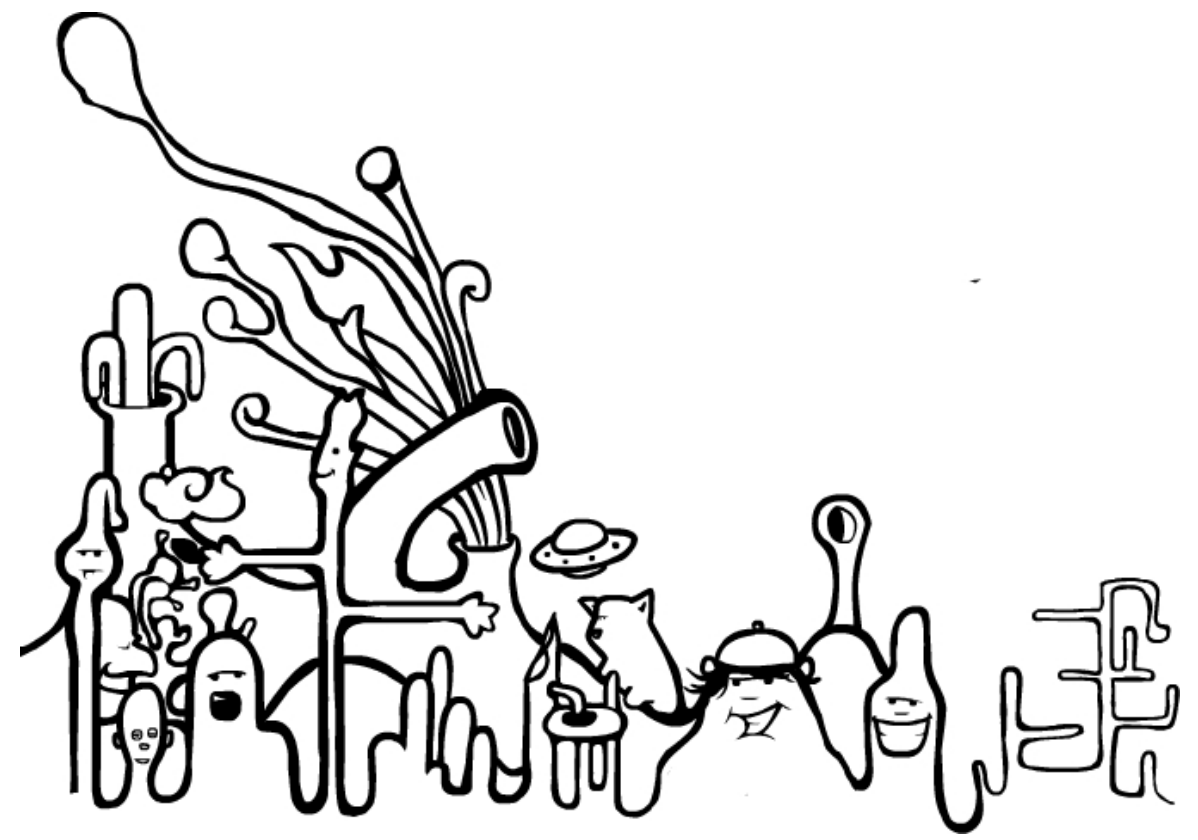

Figura 24 - Início da ilustração da parede

O processo de formação da ilustração foi a criação de diferentes elementos e a incorporação desses com os já presentes, de forma a conectá-los de uma maneira sutil. 


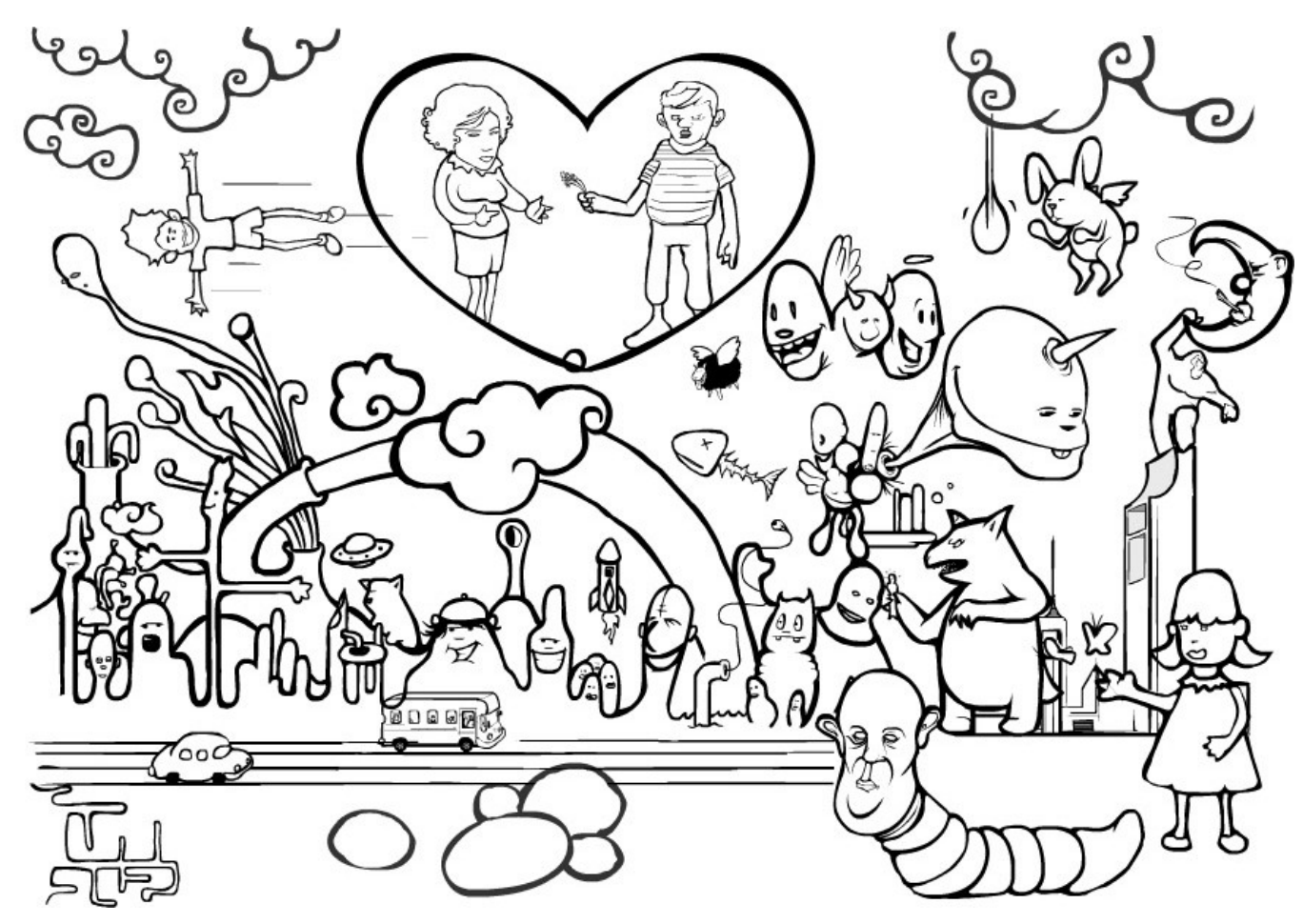

Figura 25 - Metade do processo de geração da ilustração

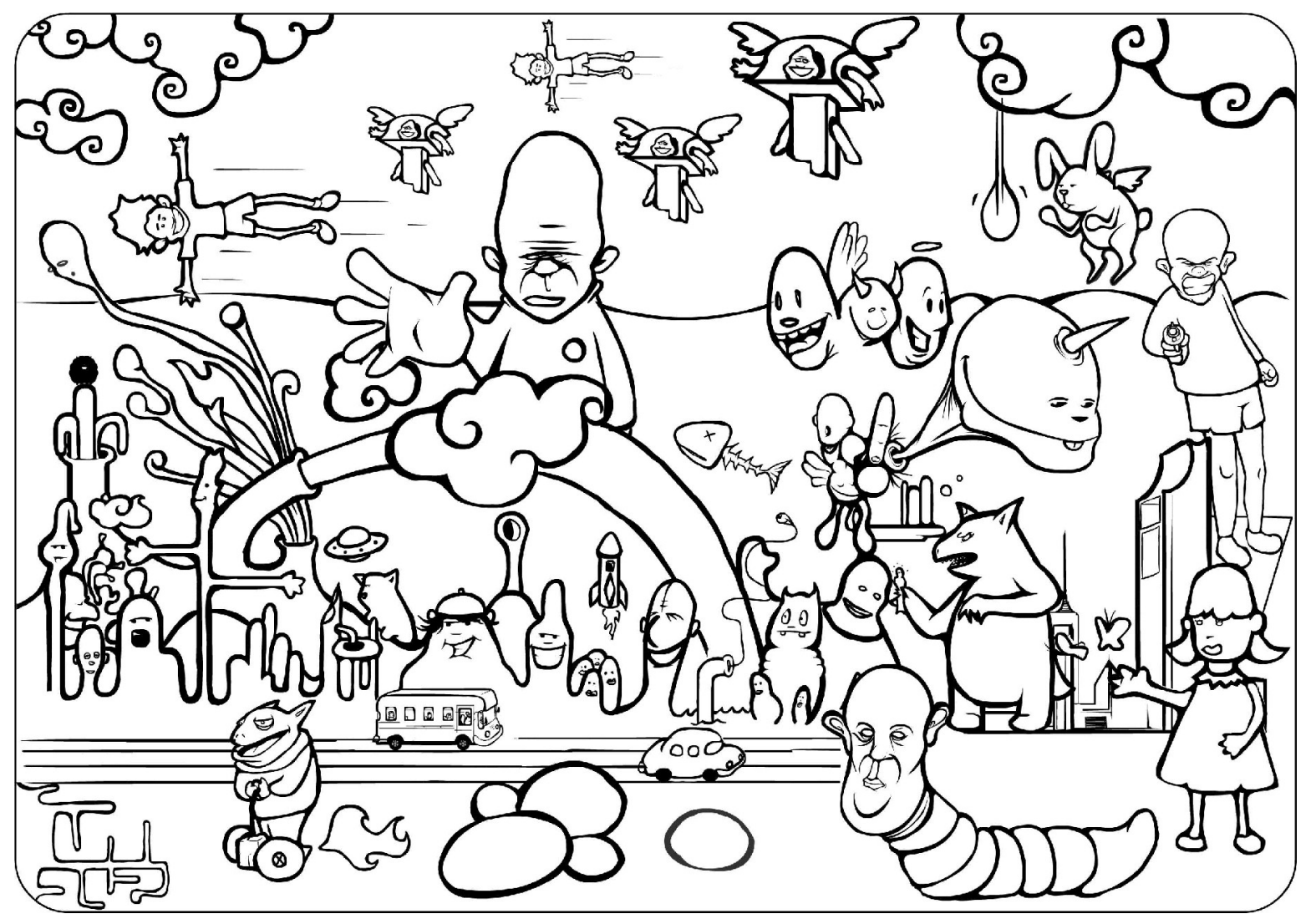


Figura 26 - Ilustração final

\subsection{1 - Conclusão da geração da ilustração}

A ilustração final foi escolhida por ser aquela que reuniu os elementos de forma mais caótica mas ao mesmo tempo harmônica das opções criadas. Nela há um equilíbrio dinâmico entre os espaços vazios e os espaços ocupados. A hierarquia de linhas define bem o estilo de grafite pretendido. A temática também cumpre bem esse requisito, tendo elementos caricaturizados ambientados em um universo fantástico.

\section{2 - Marcas}

Durante o processo de geração das alternativas da marca, surgiu a alternativa de utilizar a sigla do nome do bar (B.O.N.) para suavizar o nome do bar. Essa idéia se apóia também no fato de essa sigla remeter ao adjetivo "bom", carregando assim uma significação mais positiva. Foram confeccionadas, então, marcas com a sigla e sem ela.

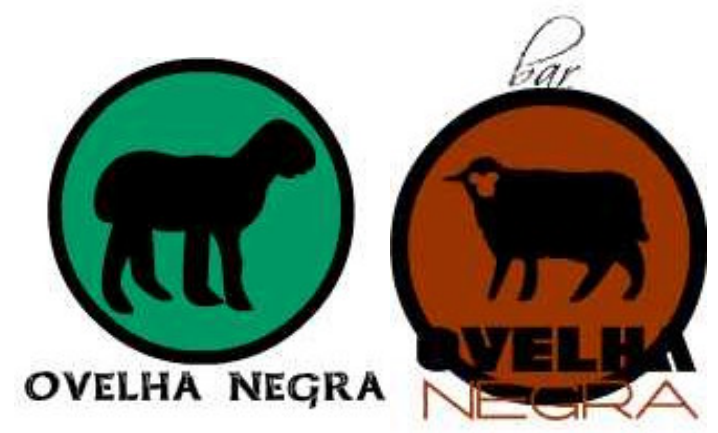

Figura 27 - Primeiras alternativas de marca 
As primeiras alternativas utilizavam ovelhas em negativo de perfil inseridas em um círculo. A idéia do círculo seria mantida em alternativas subseqüentes. Essas marcas porém não traziam o requisito de inovação e autenticidade que o projeto demandava e foram descartadas.
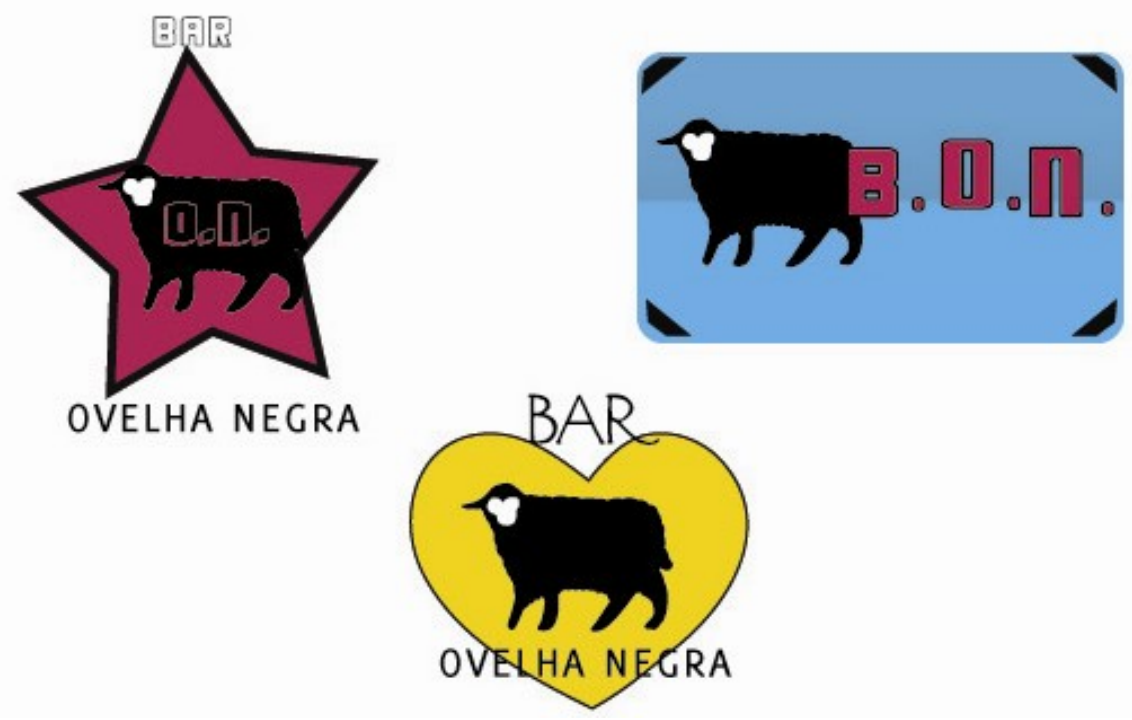
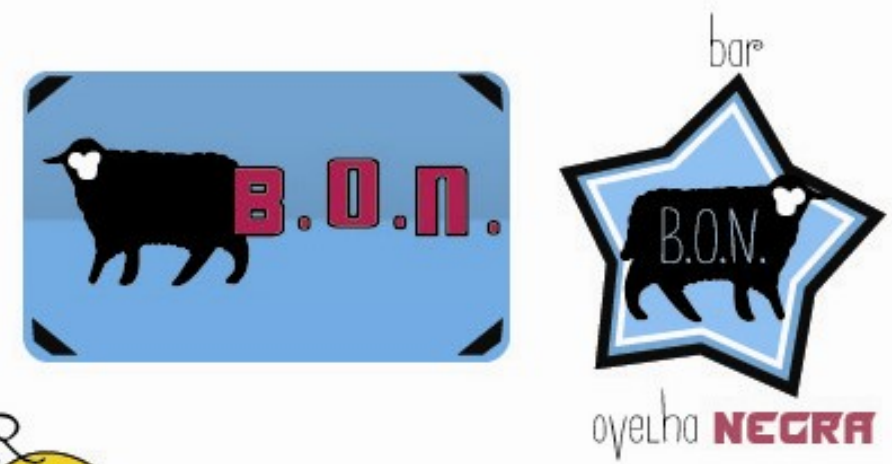

Figura 28 - Segunda geração de alternativas de marca

A segunda geração de marcas utiliza a mesma representação de ovelha mas prima por cores mais autênticas. Tentou-se com elas mudar um pouco a idéia do círculo envolta da marca, mantendo porém a idéia de utilizá-la como um brasão, sugerido pelo cliente. Foi a partir dessa geração que surgiu a idéia de utilizar a sigla B.O.N. como forma de suavizar o nome do bar. Essas marcas no entanto, figuraram-se frias demais e com poucos elementos que as pudesse remeter a bares, sendo então descartadas.
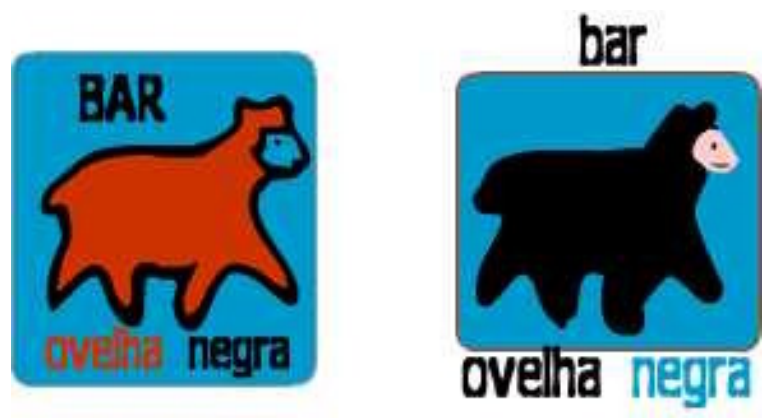

Figura 29 - Alternativa com linhas e em negativo 
Nessa alternativa as ovelhas foram inseridas em um quadrado com quinas arredondadas. A idéia era que a marca se parecesse com um selinho de produtos. No entanto, não conseguiu remeter à idéia de bar.

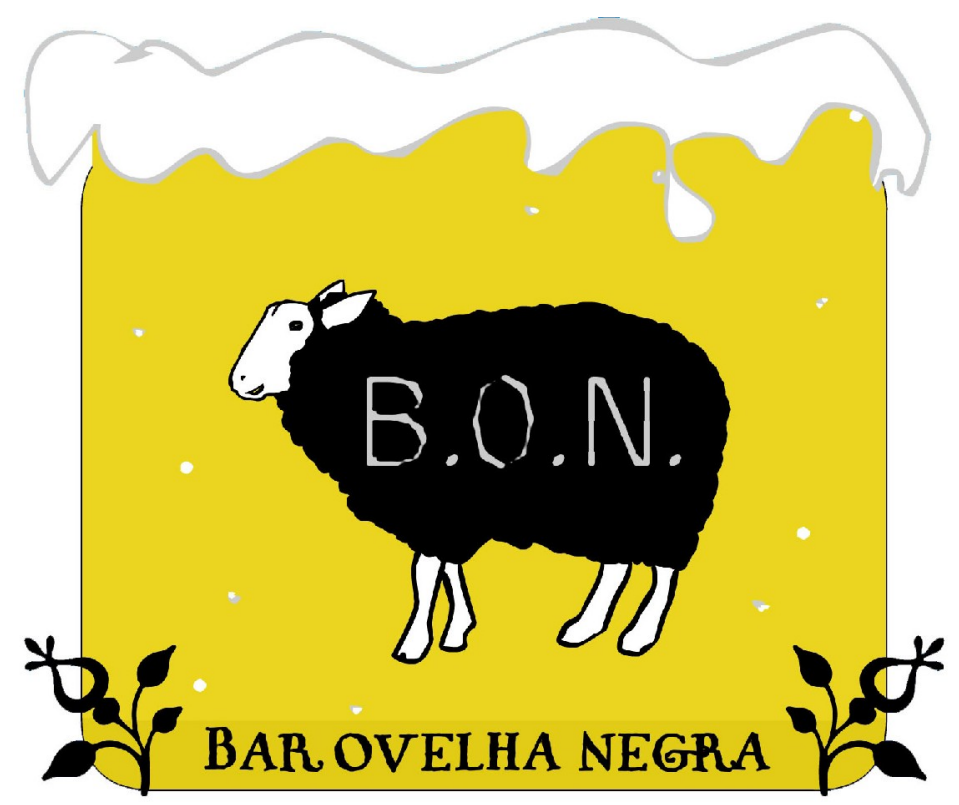

Figura 0- Marca utilizando a sigla de Bar Ovelha Negra (B.O.N.) e o nome

Essa marca foi desenvolvida utilizando as cores da cerveja e alguns ornamentos que são comuns também em rótulos dessa bebida. O objetivo foi reforçar a idéia do principal produto que será vendido no bar. O grande número de elementos contudo prejudicaria a sua utilização. A representação muito realista da ovelha foge também da proposta inicial do projeto. Por isso a marca foi descartada. 


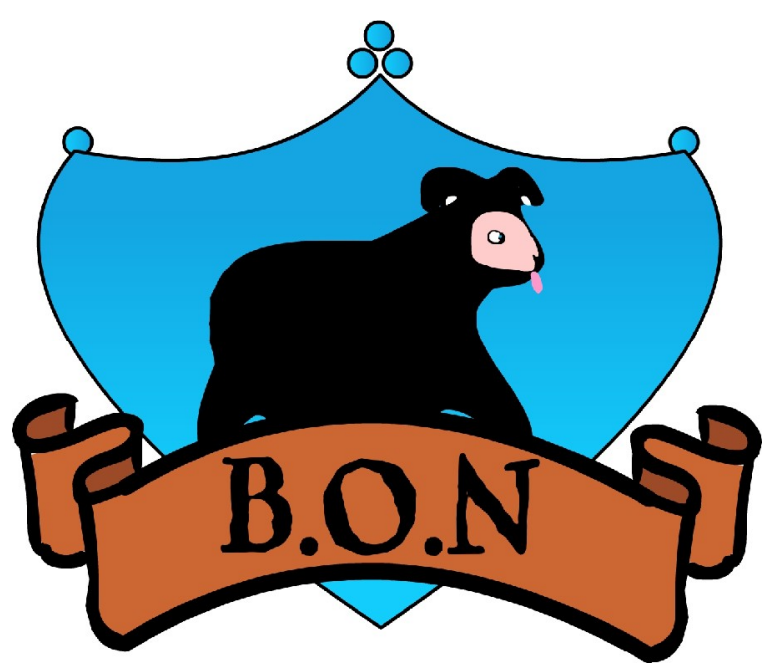

Figura 31 - Marca em formato de brasão utilizando a sigla sem o nome completo

A segunda marca foi projetada em formato de brasão, realçando o aspecto de corporação que o demandante citou como uma das estratégias de fidelização de clientes para o bar. Ela não conseguiu dar a idéia de se tratar de um bar e ficou muito distante do cliente, com pouco apelo afetivo e foi descartada.

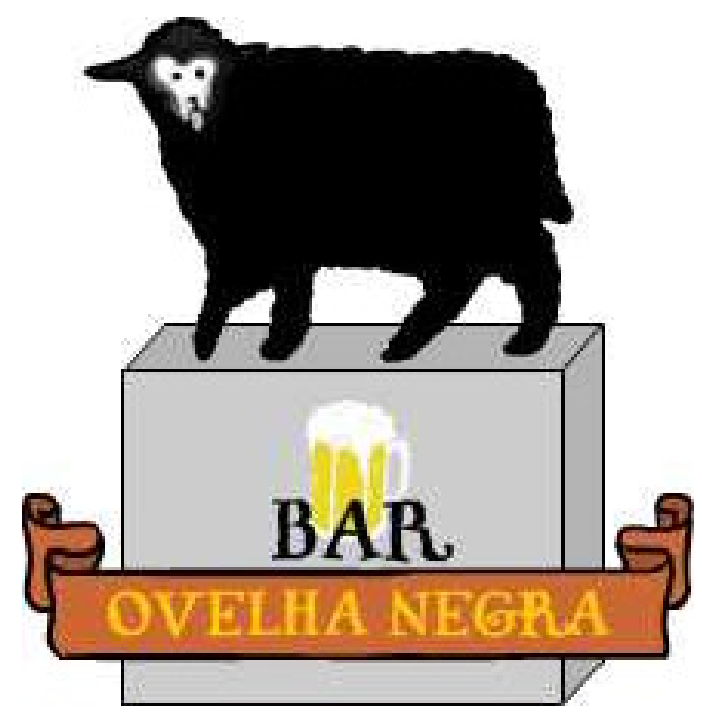

Figura 32 - Marca sem a sigla usando também a caneca de cerveja

Nessa marca, prezou-se o traço cômico da ovelha, para suavizar novamente a idéia de ovelha negra como algo problemático ou triste. Foi adicionada uma caneca de cerveja pra reforçar a idéia de bar e a ovelha foi colocada numa espécie de pódio. O pano 
tremulando foi novamente utilizado para manter a idéia de escudo ou brasão. A marca porém ficou com cores pouco interessantes e com linhas retas demais.

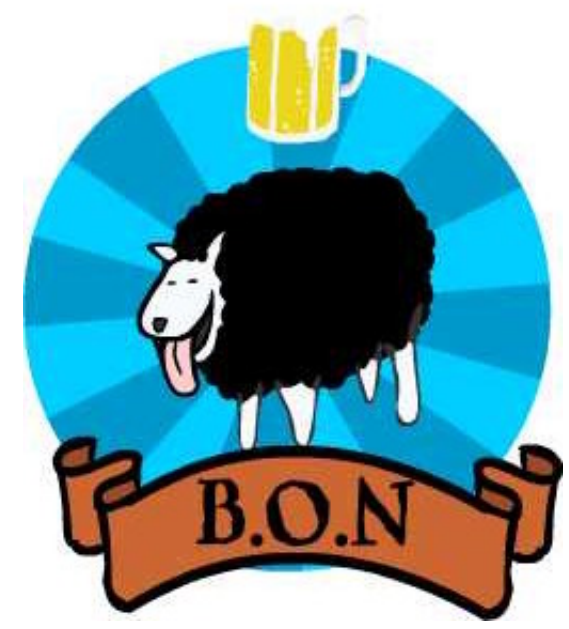

Figura 33 - Quarta marca da geração de alternativa

Para essa marca, pensou-se num círculo com a ovelha no centro como num pôr-dosol, também com o objetivo de representar alegria. Não foi utilizado o nome do bar, apenas a sigla, com o mesmo intuito. A caneca de cerveja foi novamente adicionada, para chamar a atenção para o tipo de estabelecimento. Essa marca, no entanto, ficou muito desconexa, com elementos de estilos muito diferentes, sendo assim descartada.

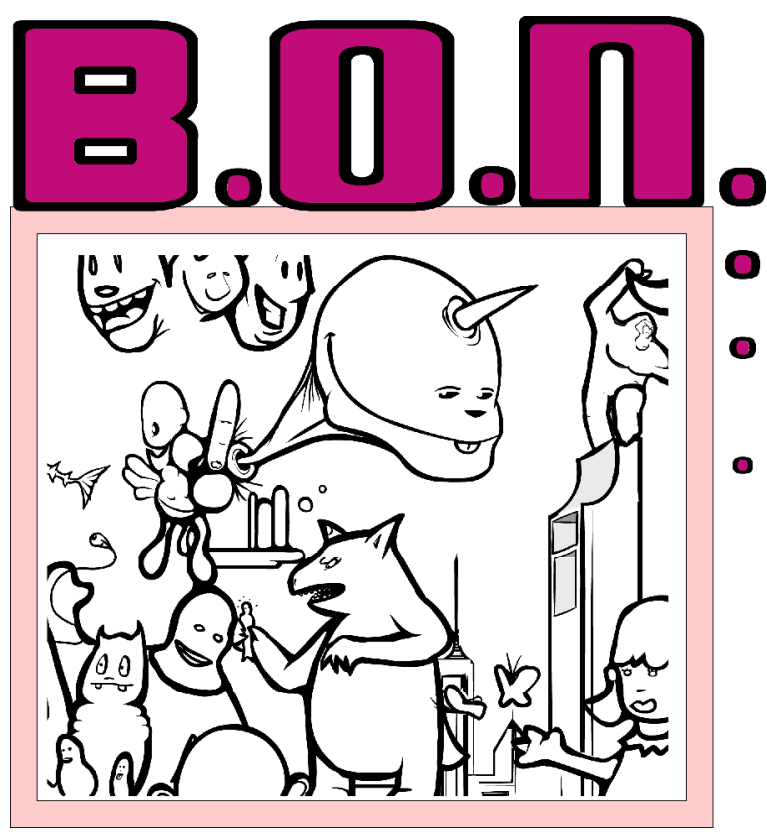


Figura 34 - Marca sem elementos representativos

Nessa marca, utilizaram-se apenas elementos do estilo grafite remetendo diretamente à ilustração feita para o interior do bar. Foi uma forma encontrada de se libertar do estilo seguido nas gerações anteriores. Foi usado um recorte da ilustração e a sigla do bar.

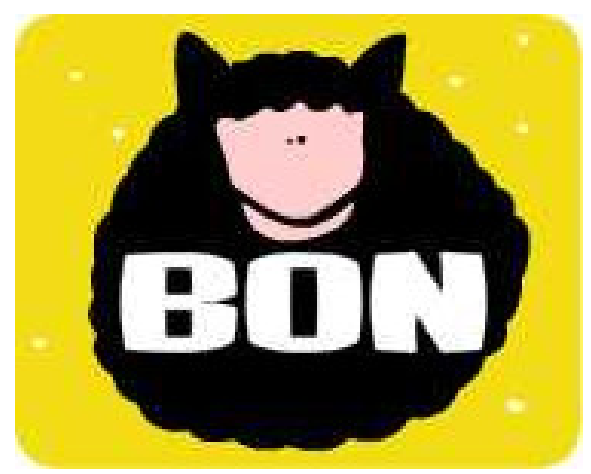

Figura 35 - Alternativa de marca com ovelha mais estilizada

A partir dessa geração a ovelha foi feita de forma mais estilizada, fugindo um pouco da sua representação de corpo inteiro em perfil, como estava sendo feito. A idéia era apresentar a ovelha de forma mais próxima com seu rosto bem à vista. Primou-se então por uma representação de formas mais simples tentando desenhá-la em um círculo. No caso dessa marca, a cor amarela foi utilizada para representar a cerveja. Essa marca no entanto ficou demasiadamente simples e com cores muito pouco relacionáveis. 

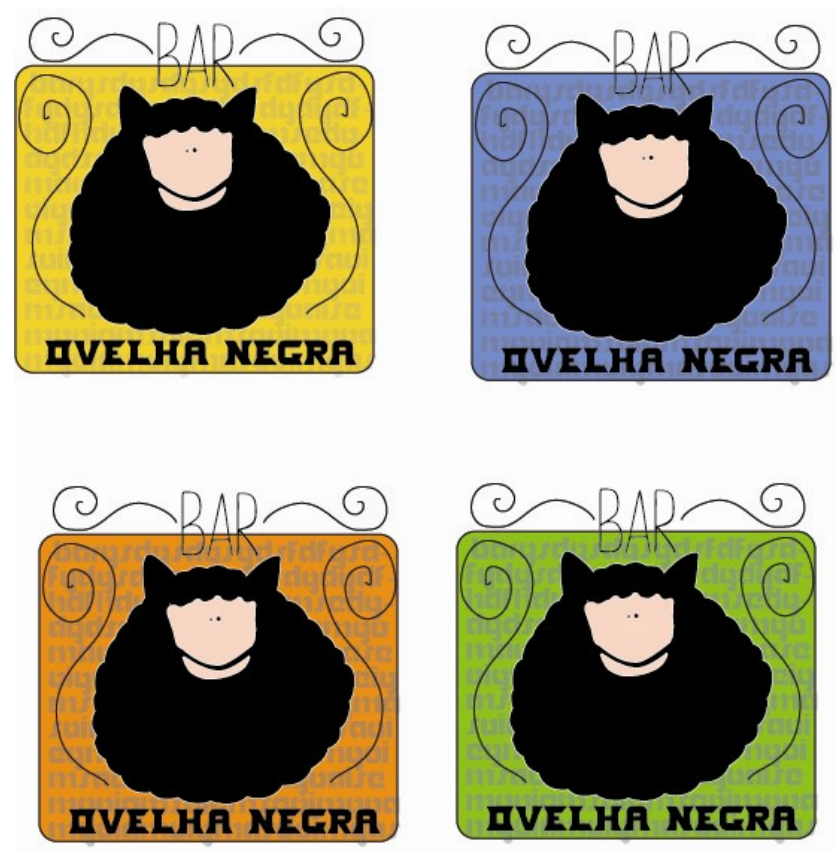

Figura 36 - Marcas utilizando a ovelha mais arredondada

Nessa marca foram utilizados ornamentos para demonstrar tradição, elemento importante na identidade de um bar, e a mesma ovelha foi mantida. $\mathrm{O}$ resultado final não agradou pelo excesso de elementos.

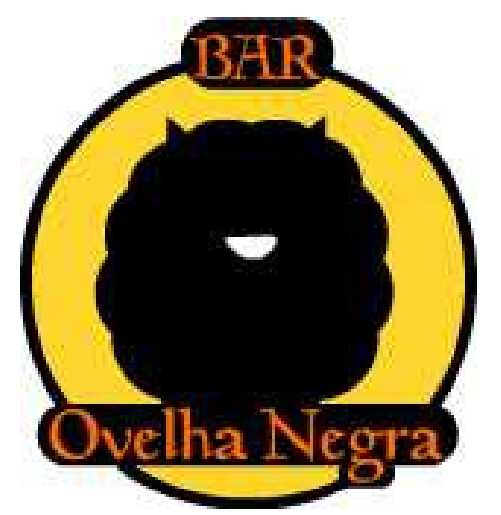

Figura 37 - Marca utilizando uma ovelha ainda mais estilizada

Na geração conseguinte de alternativas tentou-se estilizar ainda mais a ovelha para que sua reprodução fosse facilitada. A ovelha então ficou mais arredondada ainda, assemelhando-se a uma nuvem, o que faz sentido tratando-se de ovelhas. O círculo retornou e a palavra bar foi mantida separada do nome,como na alternativa anterior. Durante o processo de simplificação do desenho da ovelha alguns elementos importantes para a identificação dela, se perderam, como olhos e boca, o que resultou em um problema. 


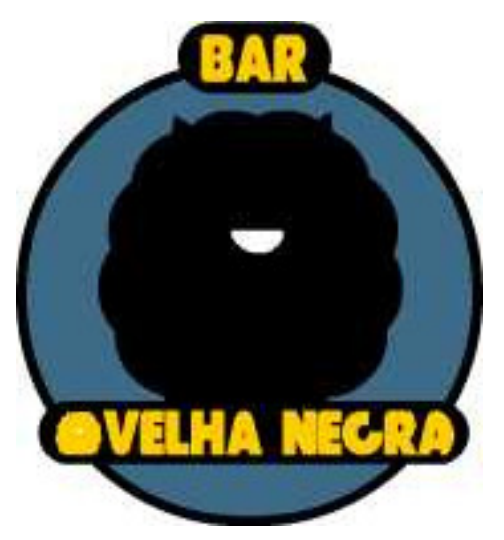

Figura 38 - Marca utilizando a mesma ovelha e uma tipografia mais trabalhada

Nessa marca foi utilizada a mesma ovelha, mas nela a tipografia foi mais trabalhada, repetindo o desenho da ovelha para formar o "o". Essa marca no entanto ainda não cumpria os requisitos estabelecidos.

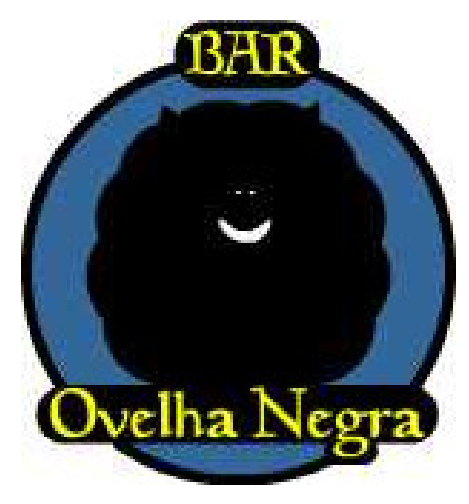

Figura 39 - Mesma marca com a adição dos olhos

Nessa alternativa o elemento dos olhos foi recolocado para resolver o problema exposto anteriormente.

Durante as discussões com o demandante, foi pedido que a marca buscasse um caminho menos lúdico e simpático, algo mais "agressivo" nas suas palavras. A partir daí, foram feitas alternativas anacrônicas que não seguiriam o caminho que estava sendo tomado. Essas alternativas não satisfizeram os objetivos da marca, mas a parte da tipografia demonstrou uma grande evolução e foi mantida nas alternativas seguintes. 


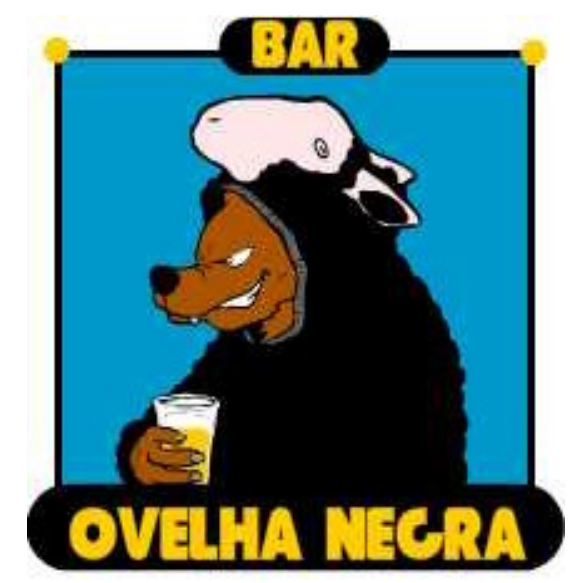

Figura 40 - Marca com idéia mais agressiva

Com o pedido do demandante, foi feito um desenho seguindo uma idéia de mais agressividade. A idéia era de um lobo vestido de ovelha negra tomando cerveja. Essa alternativa foi então simplificada chegando numa versão com poucos detalhes. O objetivo seria conquistar o público pelo humor contido na idéia da marca. Haveria então um equilíbrio entre o lado positivo da marca, com o humor empregado, e o lado agressivo proposto pelo cliente.

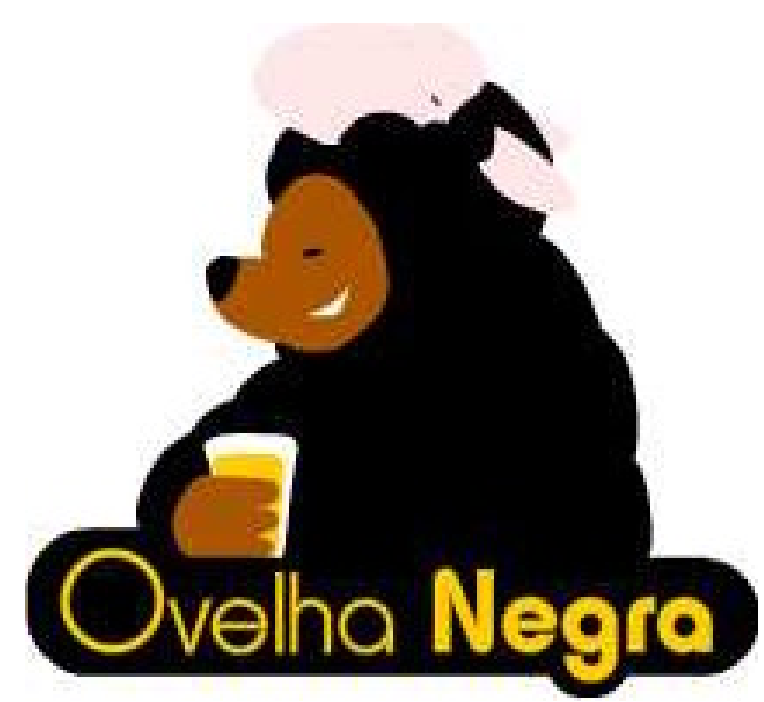

Figura 41 - Versão estilizada da marca anterior 
Essa versão é uma versão simplificada daquela feita com a idéia do lobo. Nesta as linhas foram retiradas deixando o contorno a cargo totalmente do preenchimento colorido do desenho. O objetivo foi diminuir um pouco o aspecto agressivo, mantendo porém a idéia principal.

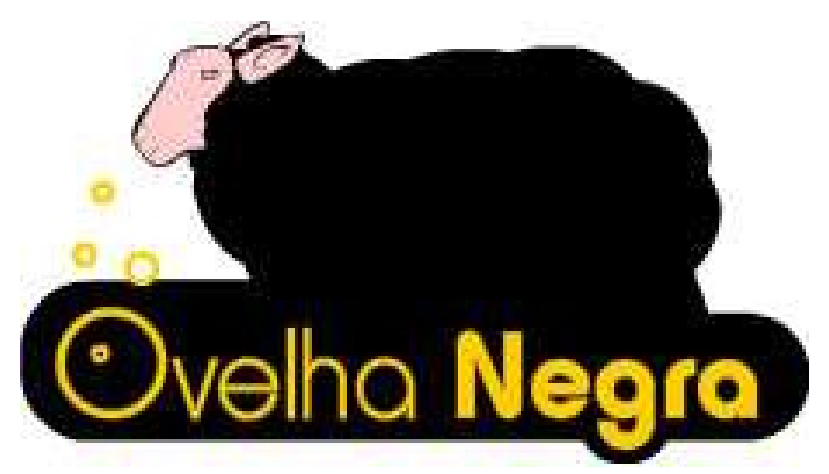

Figura 42 - Versão com mesma tipografia e ovelha por inteiro

Mantendo a tipografia, trocou-se o lobo por uma ovelha de perfil, quase sem estilização. Essa alternativa foi diretamente proposta pelo demandante também. O resultado obtido ficou fora dos objetivos propostos. A ovelha de perfil assim, impassível, não passa o sentimento desejado. Ela deveria ser empática como levantado nos requisitos.

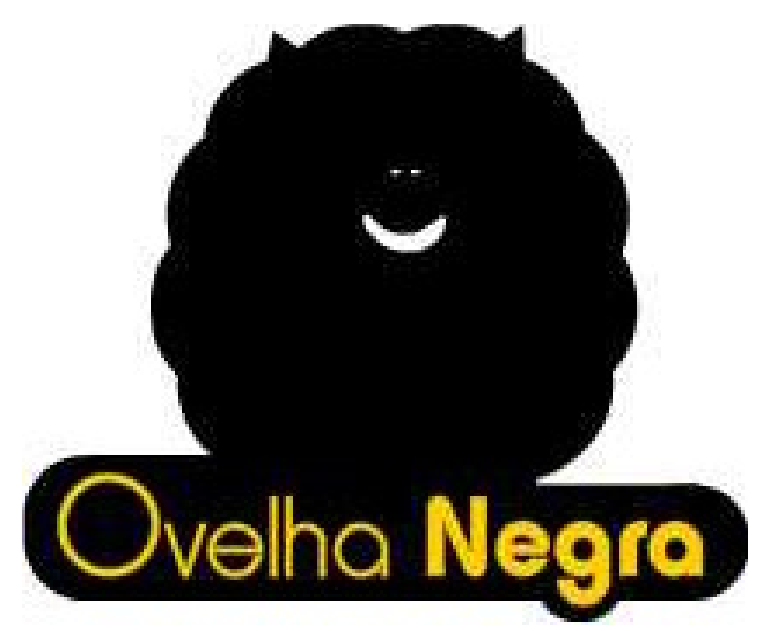

Figura 43 - Versão híbrida misturando opções

Nessa versão, misturaram-se duas versões. Como a ovelha mais estilizada tinha cumprido os requisitos propostos e agradado visualmente, tentou-se adicioná-la diretamente ao logotipo escolhido. A tentativa surtiu efeito e o resultado agradou, porém a assimetria da espessura da barra contendo o nome ainda causava um certo desagrado visual. Para resolvê-lo, a espessura da esquerda foi espelhada na direita. 


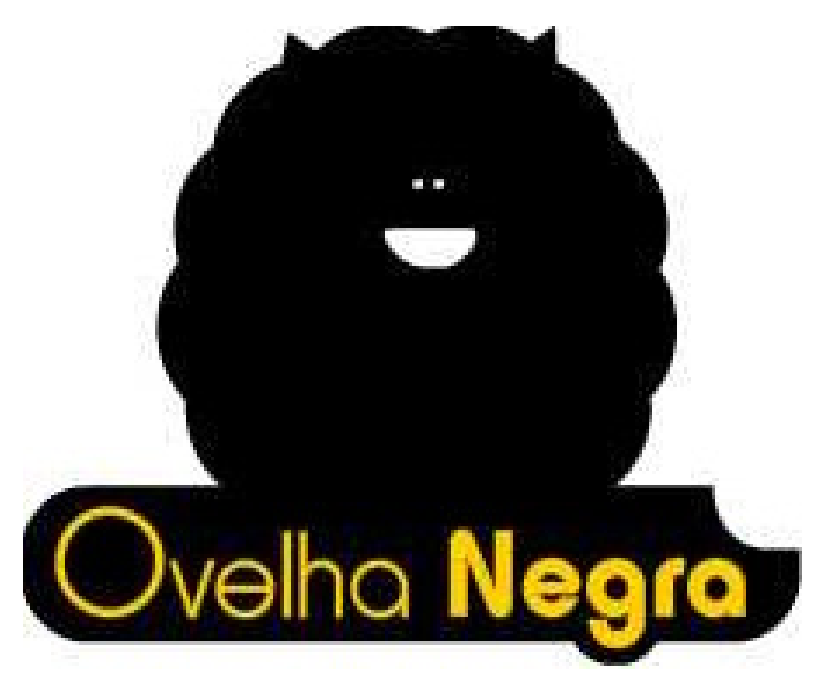

Figura 44 - Versão com a ovelha arredondada e o sorriso maior

A partir dessa versão fez-se apenas uma última modificação no sentido de harmonizar a tipografia. Percebe-se pelo desenho que a ponta da letra "v" fere o "o" pois há um grande contraste entre a ponta da letra "v" e a "barriga" da letra "o". Para resolver isso a letra "v" foi modificada, tendo sua perna inclinada para a direita, aliviando a tensão criada.

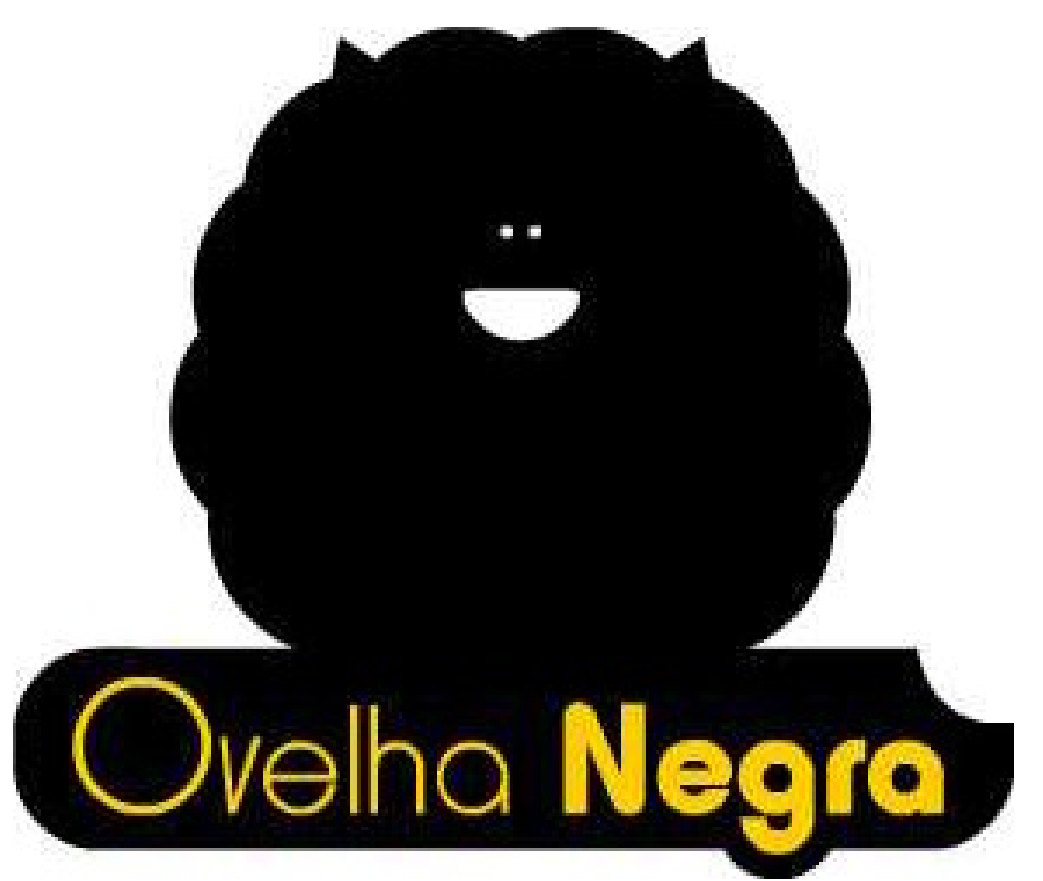

Figura 45 - Versão final para ser utilizada em fundo branco e fundos claros 
Na versão final foi tirado um 'pedaço' da marca como forma de torná-la um ouço mais assimétrica. Isso se deve ao fato de que uma marca simétrica demais acaba sendo um pouco maçante e passando, por vezes, despercebida.

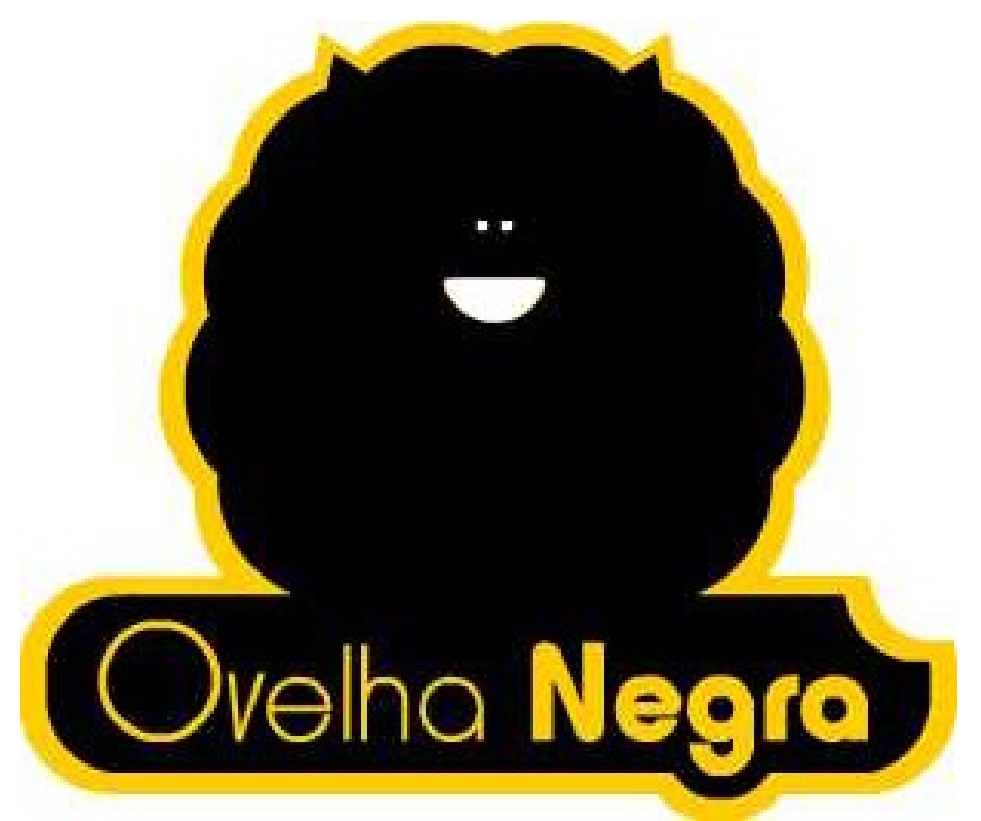

Figura 46 - Versão final para utilização em fundo preto e fundos escuros

\subsection{1 - Conclusão da geração da marca}

A versão escolhida abrange todos os requisitos inicialmente definidos no projeto. É uma marca simpática que atrai a atenção dos clientes. O contraste do amarelo ouro com preto é bastante chamativo e remete também a cerveja, pelo amarelo. A tipografia é representativa pois, utilizando uma mesma fonte em versão Thin e Fat faz referência ao contraste entre as ovelhas brancas e as negras, realçando o nome 'negra'. Uma marca de fácil reprodução que certamente poderia ser estampada com orgulho pelos clientes.

\section{3 - Cartão Corporativo}




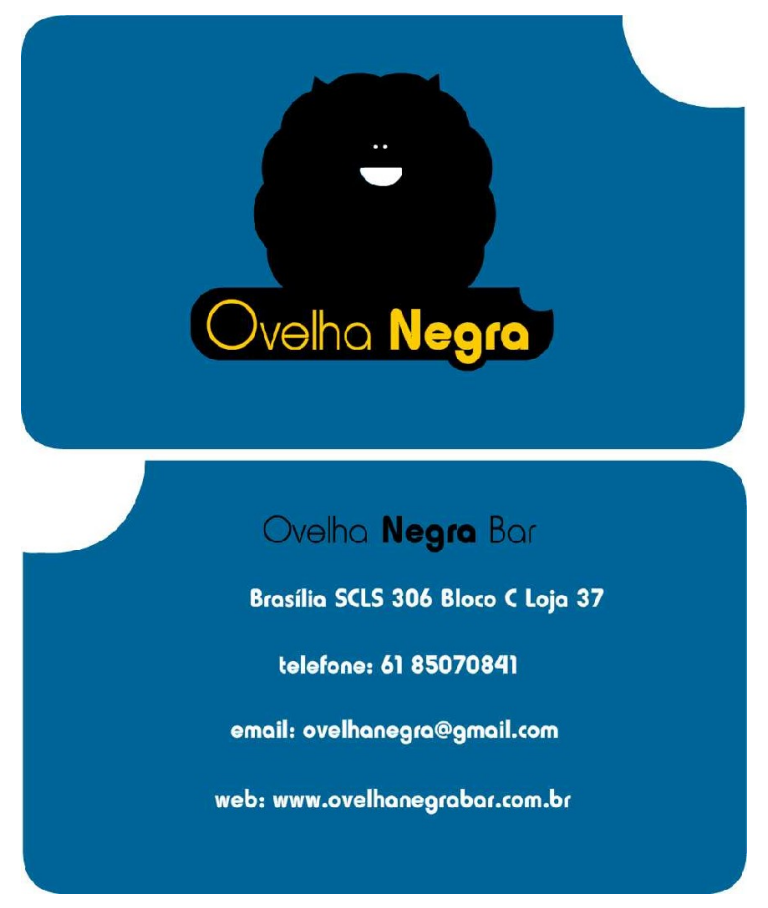

Figura 47 - Cartão corporativo da empresa

No cartão corporativo foi utilizada a idéia de reproduzir o corte feito na marca imprimindo-lhe um diferencial. Na face do cartão há apenas a marca, como uma forma de reforçá-la, colocando toda a informação no verso do cartão. O tamanho do cartão, $5 \mathrm{~cm}$ de altura por $9 \mathrm{~cm}$ de largura foi planejado para que coubesse na maioria das carteiras produzidas atualmente. Suas quinas arredondadas, além de remeterem diretamente à forma da marca, ajudam na preservação do estado do cartão, pois suas quinas não ficam expostas a desgastes e dobras. 


\section{4 - Porta-Copos}



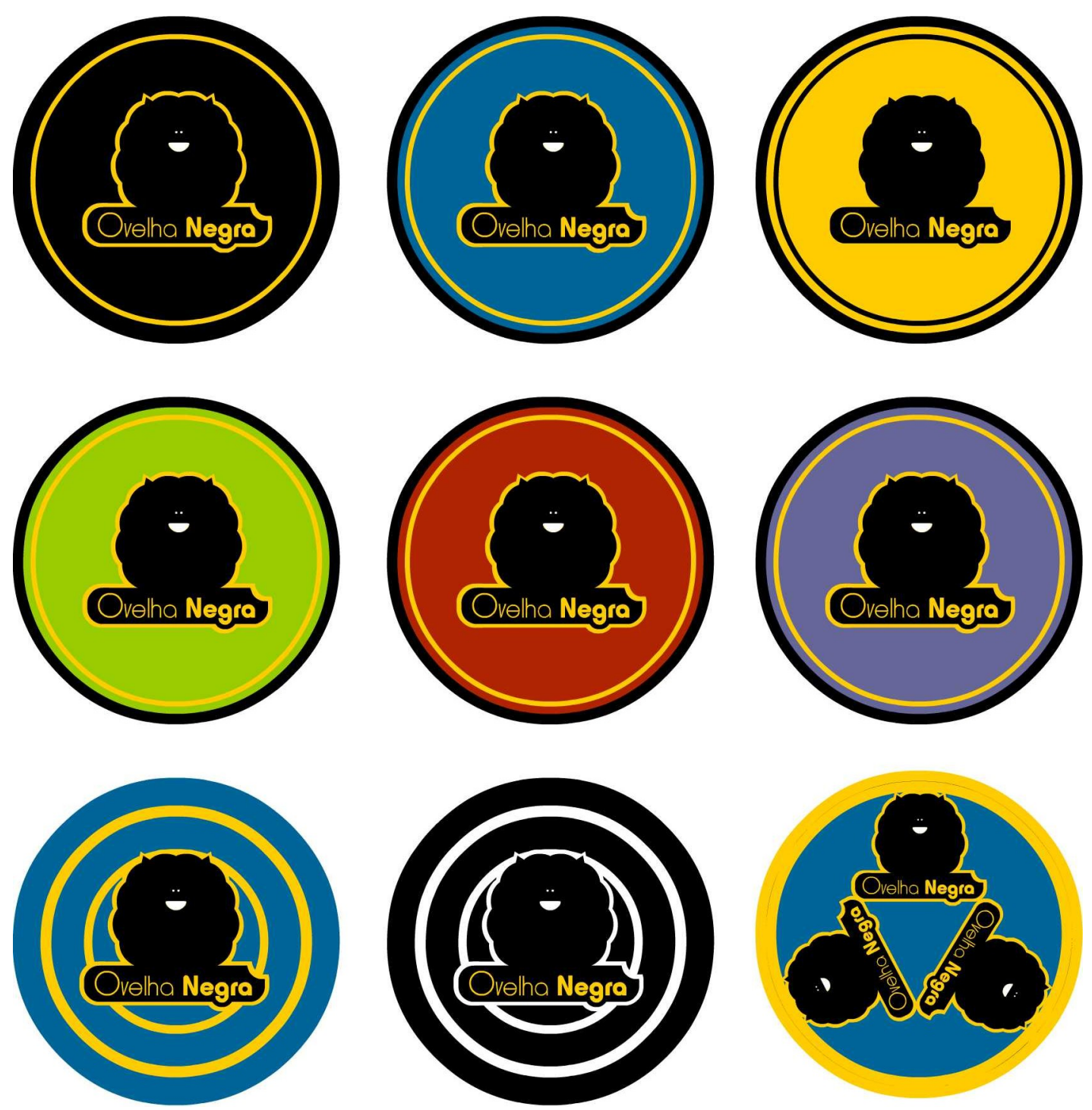

Figura 48 - Porta-copo de absorção do 'suor' da cerveja para mesas de madeira

Os porta-copos foram feitos utilizando-se todas as cores auxiliares propostas pelo projeto de forma a obter um grande número de variações para, assim, estimular o desejo de colecioná-las pelos clientes. Seu formato segue o formato usual desse produto no mercado: $10 \mathrm{~cm}$ de diâmetro. A variedade de cores proporcionará uma mesa colorida aos clientes à medida que variem os modelos colocados pelos funcionários. A notória prática dos clientes de bar de colecionarem esse produto seria estimulada, divulgando a marca do bar.

\section{5 - Cardápio}




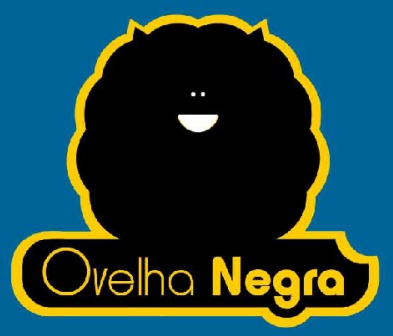

Petiscos

\section{Drinks}

800 301 Bolinho de Bacalhau \$15, 00 2\$7, 00

\$02 Tábua de Frios RS10, 00

303 Bolinho de Arroz com Quejo R\$8, 00

100 Asinha de Frango R58, 00

\$04 Asinha de Frango Rs8, 00

101 Batatas Bravas com molho picante R510, 00

102 Batatas Fitios RS11, 00

$\$ 05$ Batatas Bravas com molho picante R\$3, 00

306 Batatas Fitas R\$3, 00

103 Bolinho de Bacalhau R515, 00

104 Mandioco Frito R57, 00 105 Tábua de Frios R510, 00 Bebidas 106 Bolinho de Arroz com Quejo RS15, 00

400 Água Sem Cás $\mathrm{R} \$ 3,00$

107. Frango a Passarinho Picante RS11, 00

401 Água com Cís R\$2, 00

108 Moluscos Frescos com Farinha RS12, 00

402 Água Tônica R\$3, 00

109

Isca de Peixe Frito R\$13, 00

103 Coca-Cola $\mathrm{R} \$ 2,50$

HO

Comarão Frilo no Azeite R520, 00

40.4 Guaraná Antarctica R\$2, 00

200 Sanduichinho de Mortadela Ceralti RS12, 00

405 Soda Limonada $R \$ 2,00$ 201 Torrada de Quejio e Bacon R58, 00

406 Suco Mais - Lata $2 \$ 3,00$

202 Almôndegas ao Molho Sugo R59, 00

407 Suco Natural de Laranio $20 \%$ Azeitonas, Palmitos $\Theta$ Milhinhos R510, 00 R\$4, 00

Figura 49 - Frente do Cardápio 


\section{Cervejas}

\section{Tabacaria}

500

Corona - Mexicana

501 San Miguel - Espanholo

502 Xibeca - Espanhola

$503 \quad 5 k o l$

504

Antarctica

505

506

Brohma

R $\$ 3,00$

507

Bohemia

R $\$ 4,00$

508

Heineken

509

Sol

R\$3,00

\section{Doses}

600

Tequila José Cueno

R515, 00

601

Pingo Seleta

R\$7, 00

602 Whisky Johnny Walker Red Label

R\$17, 00

603

Whisky + Energético

$R \$ 20,00$

60.4

Xiboquinho

R\$3, 00
$700 \quad$ isqueiro

R\$2, 00

701 Ciigarro de Palha Avulso

RS0, 50

702 Cigarro de Palha Maşo

R\$4, 00

703 Marlboro / Marlboro Light

R\$5, 00

204 Smoking

$R \$ 6,00$

Aceitamos

\begin{tabular}{c|} 
VISA \\
Electron
\end{tabular}

VISA

Mastercard

Ticket

Figura 50 - Verso do cardápio 
A estrutura escolhida para o cardápio é bastante simples. Uma só folha, com 18 centímetros de largura por 25 de altura, frente-verso com todos os pedidos. Dessa forma a impressão e a confecção dos cardápios são facilitadas, gastando-se menos. A tipografia auxiliar foi escolhida principalmente para o cardápio, pois se trata de um tipo que remete a marcas de fast-food e que, por isso, remete diretamente a comida.

\section{6 - Uniforme}
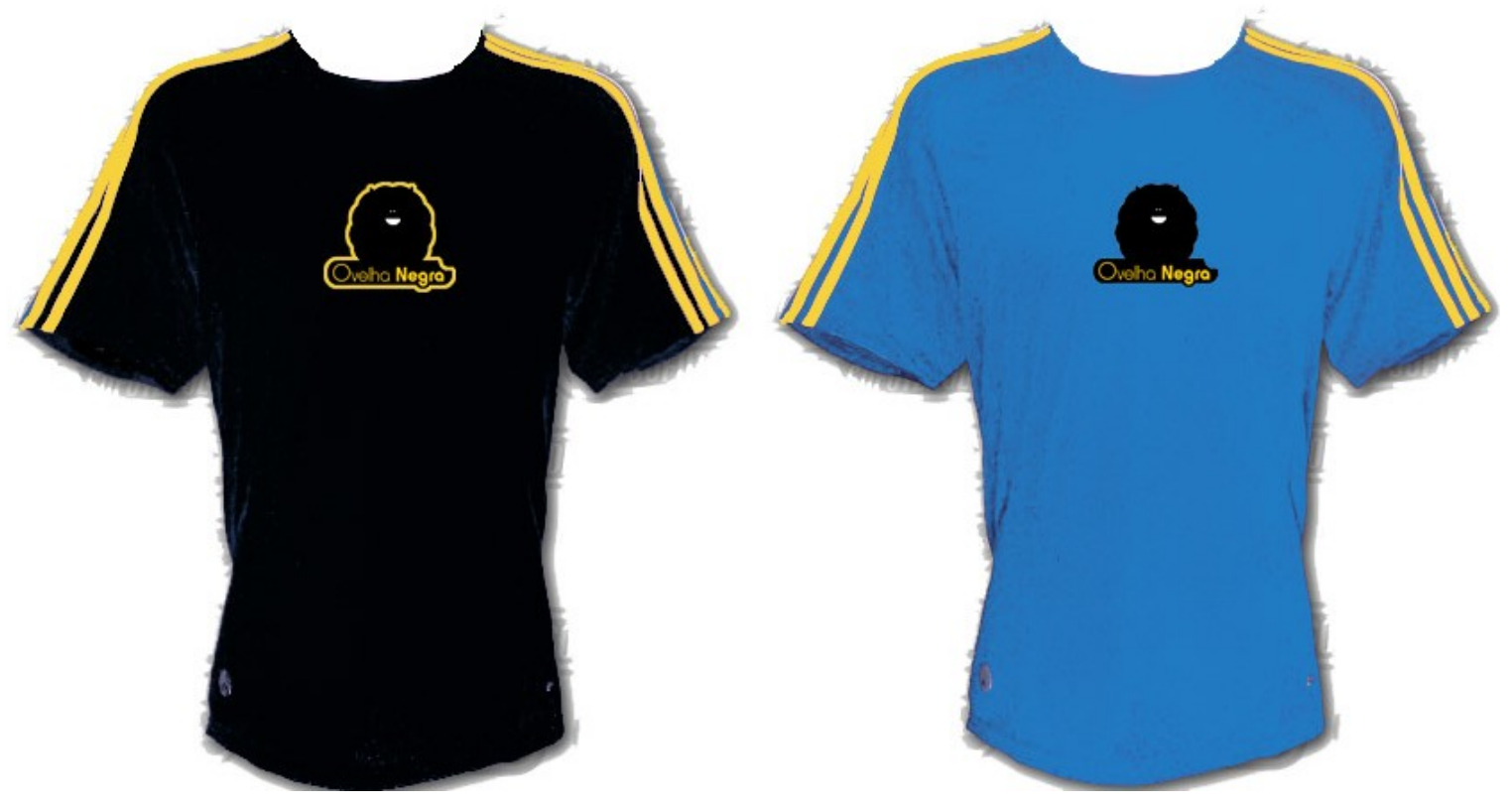

Figura 51 - Uniformes escolhidos

Para conquistar o cliente, serão usadas camisetas com duas ou três listras laterais na cor amarela. A marca será impressa no centro da camiseta. A mesma camiseta utilizada pelos garçons será vendida na loja do site e no próprio bar. 


\section{7 - Leiaute do site}

\section{Hierarquia de Conteúdo}

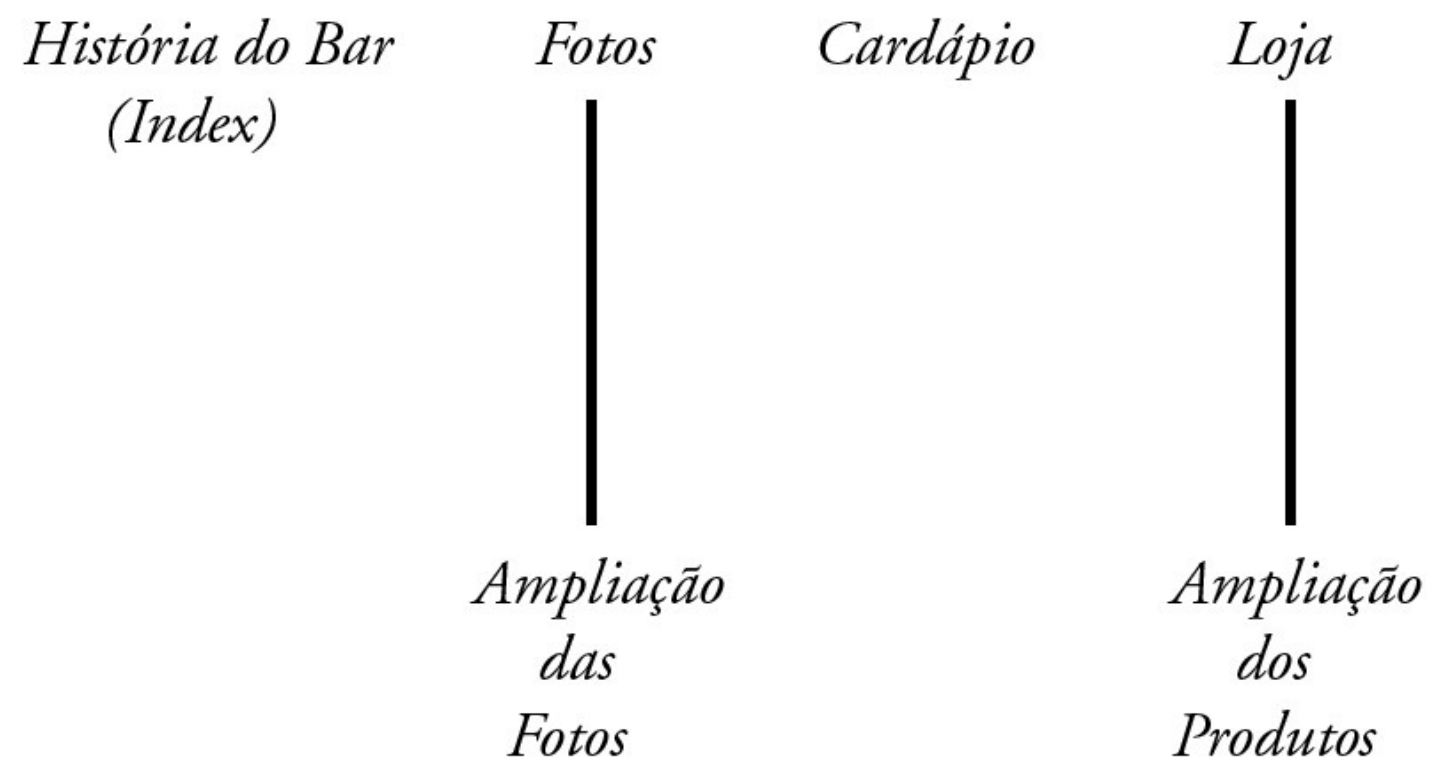

Figura 52 - Hierarquia de conteúdo do site

O site foi projetado para ser bastante simples. Apenas os itens essenciais, levantados pela pesquisa com o público-alvo e com a análise do conteúdo dos sites de bares, foram colocados. O objetivo é que o cliente visite apenas para tirar dúvidas de preços de comidas, ou conhecer mais sobre o bar. No caso da loja virtual seria uma forma de estimular também a venda dos produtos no próprio bar e eventualmente ter algum produto reservado, já que não há previsão de entregas em domicílio. 


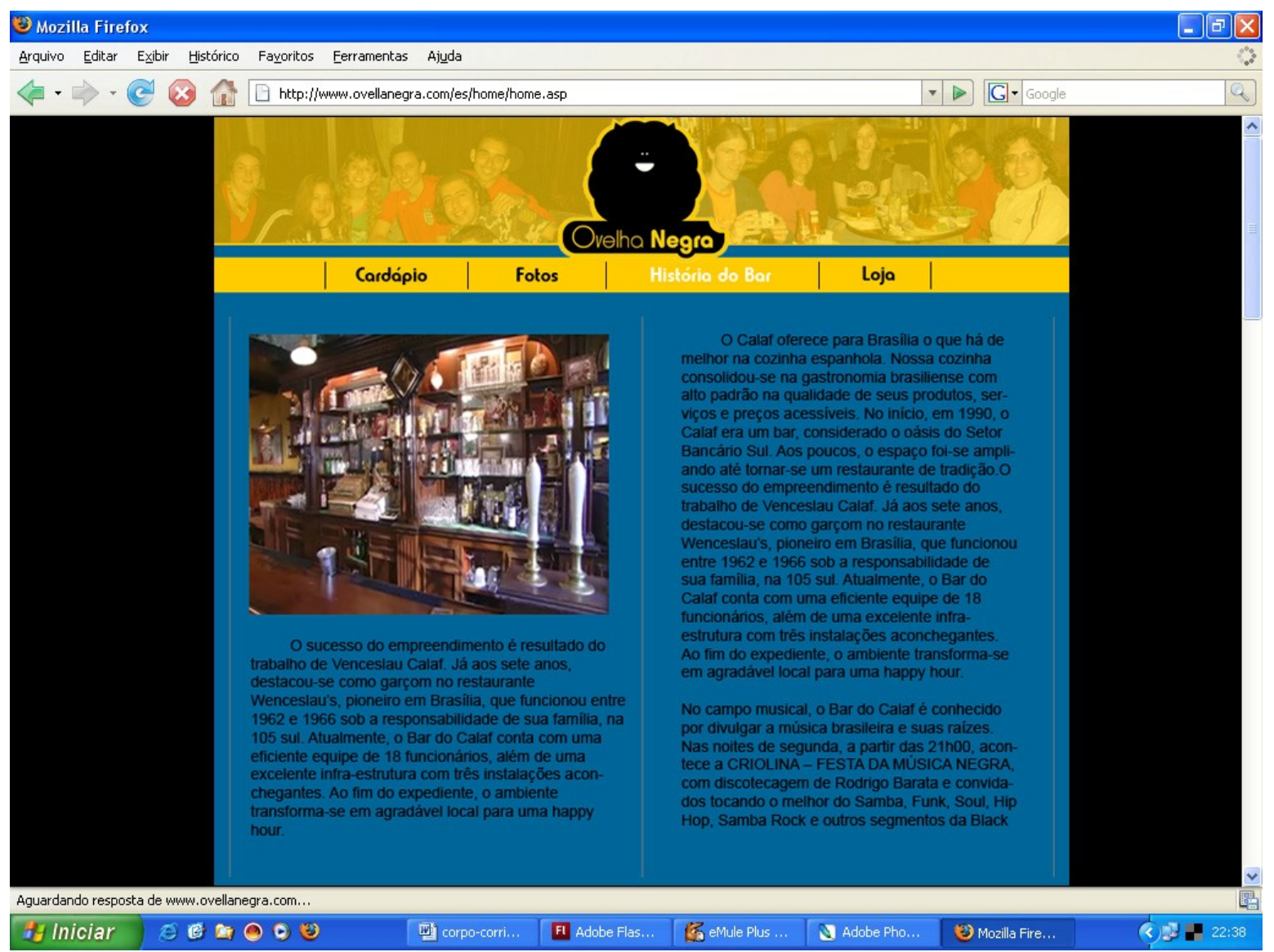

Figura 53 - Simulação no site no navegador

O leiaute do site, por ser simples, deve estar disponível ao maior número de visitantes possível. Dessa forma, a forma adotada foi a de uma janela flutuante situada no centro na tela e que suporta tanto resoluções de 800 por 600 pixels, como também resoluções mais altas de 1024 por 768 por exemplo. Dessa forma o site pode carregar mais rapidamente permitindo acessos rápidos. 

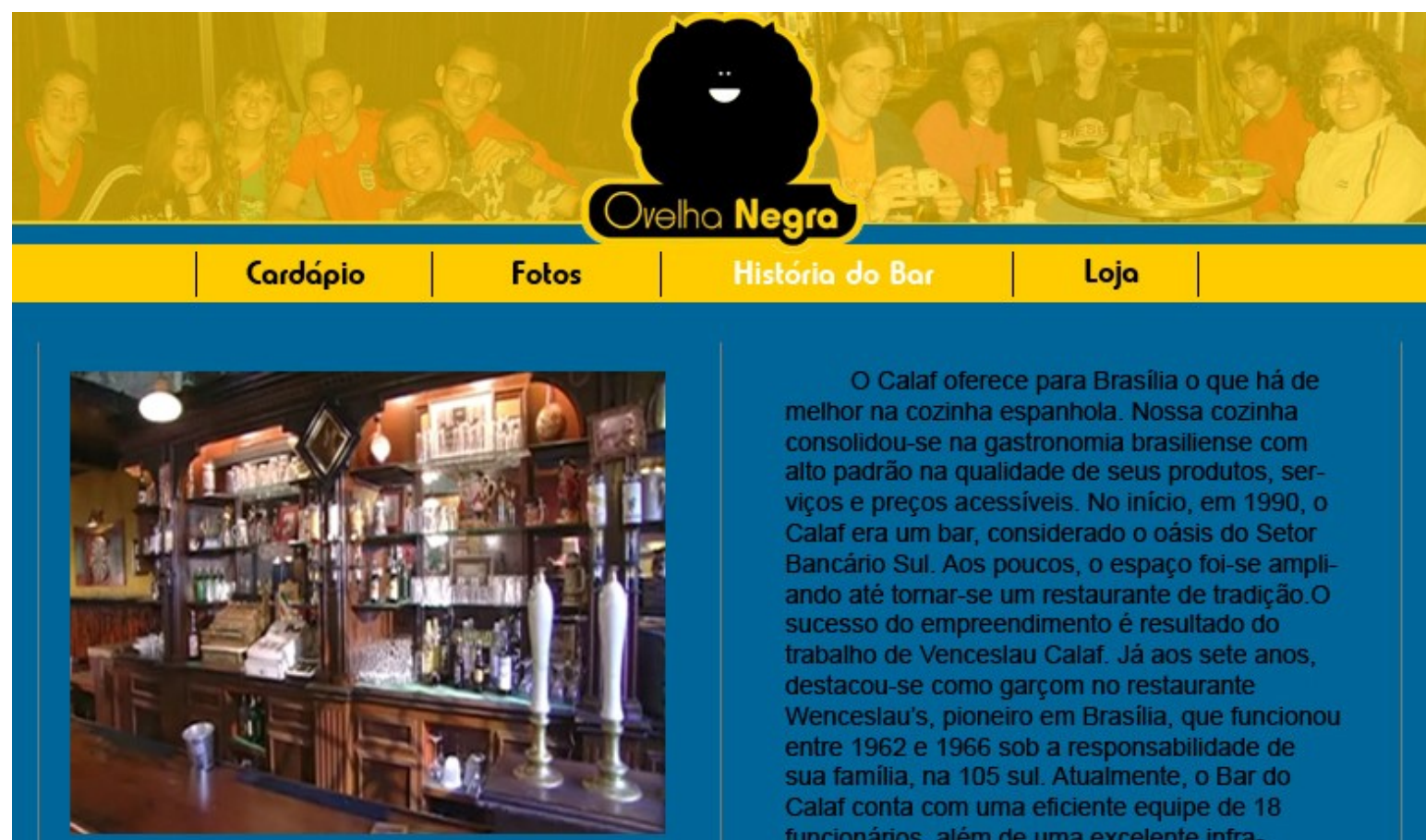

Historia do Bar

Loja

O sucesso do empreendimento é resultado do trabalho de Venceslau Calaf. Já aos sete anos, destacou-se como garçom no restaurante Wenceslau's, pioneiro em Brasília, que funcionou entre 1962 e 1966 sob a responsabilidade de sua familia, na 105 sul. Atualmente, o Bar do Calaf conta com uma eficiente equipe de 18 funcionários, além de uma excelente infra-estrutura com três instalações aconchegantes. Ao fim do expediente, 0 ambiente transforma-se em agradável local para uma happy hour
O Calaf oferece para Brasília o que há de melhor na cozinha espanhola. Nossa cozinha consolidou-se na gastronomia brasiliense com alto padrão na qualidade de seus produtos, serviços e preços acessiveis. No início, em 1990, o Calaf era um bar, considerado o oásis do Setor Bancário Sul. Aos poucos, o espaço foi-se ampliando até tornar-se um restaurante de tradição.O sucesso do empreendimento é resultado do trabalho de Venceslau Calaf. Já aos sete anos, destacou-se como garçom no restaurante Wenceslau's, pioneiro em Brasilia, que funcionou entre 1962 e 1966 sob a responsabilidade de sua família, na 105 sul. Atualmente, o Bar do Calaf conta com uma eficiente equipe de 18 funcionários, além de uma excelente infraestrutura com três instalações aconchegantes Ao fim do expediente, $o$ ambiente transforma-se em agradável local para uma happy hour.

No campo musical, o Bar do Calaf é conhecido por divulgar a música brasileira e suas raizes. Nas noites de segunda, a partir das $21 \mathrm{~h} 00$, acontece a CRIOLINA - FESTA DA MÚSICA NEGRA, com discotecagem de Rodrigo Barata e convidados tocando o melhor do Samba, Funk, Soul, Hip Hop, Samba Rock e outros segmentos da Black

Figura 54 - Página inicial do site e link História do Bar

A página inicial do site é também o link História do Bar, o objetivo disso é apresentar o bar ao visitante. 


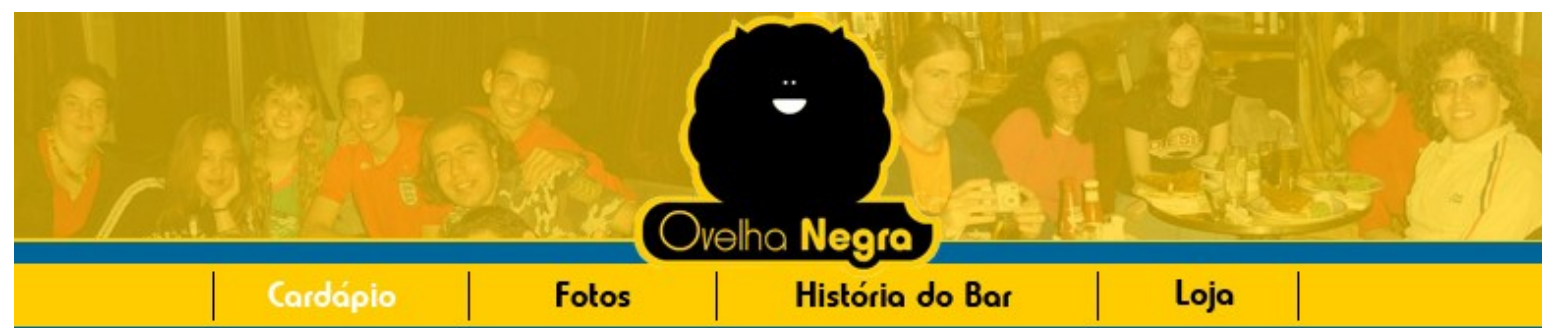

\section{Cordápio}

\begin{tabular}{|c|c|c|c|}
\hline Petisco & & 500 bito os bestow & ans. 00 \\
\hline 2001 Antroferes. & matcos & 501 Montem its & $=00$. \\
\hline 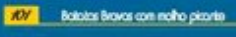 & $=0$ & 202 randofim & me os \\
\hline Nog conotitas & minos & 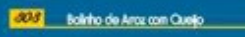 & 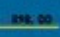 \\
\hline 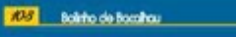 & $\operatorname{sen} 00$ & 204 unteditione & $m=\infty$ \\
\hline Dof Montentit: & $=2 . \infty$ & 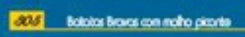 & $\ln _{2} \infty 0$ \\
\hline los rasodotios. & whe os & 2001 comitess & $=02.60$ \\
\hline 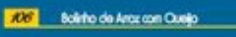 & tens. at & & \\
\hline 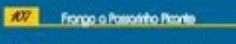 & $\rightarrow \infty$ & & \\
\hline 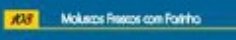 & 892.00 & is & \\
\hline 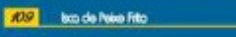 & $=0100$ & 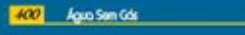 & $\ln 200$ \\
\hline Hol conodoribnotato & Nene 00 & thet basmlat & $\sec , 00$ \\
\hline 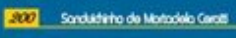 & $\sin 00$ & 108 bontans & $\sin \infty$ \\
\hline Sed lande do arebobom & sesece & thas $\cos c 0$ & 10200 \\
\hline 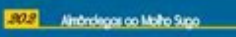 & m.co & 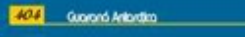 & $=2 \infty$ \\
\hline 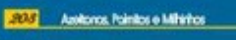 & whe od & For satumonots. & +20. \\
\hline then $\sin 40 x-100$ & $=02.60$ & & \\
\hline 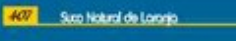 & wedo & & \\
\hline 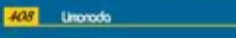 & mos & & \\
\hline
\end{tabular}

\section{Cervejas}

S00 Com- nutoro

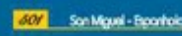

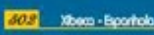

sos 50

Bor Abets

sos soins

306 ard

$B 07$ stans

उes then

$300 \quad 50$

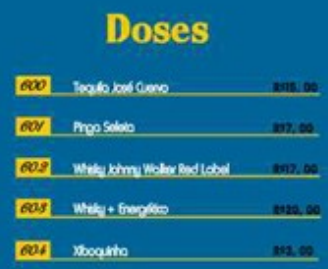

\section{Tabacaria}

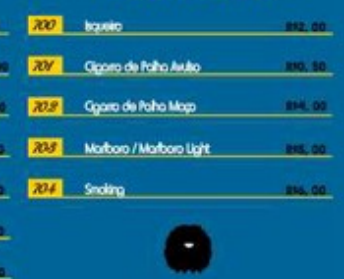

Aceitamos

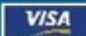

Electron

VISA

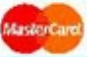

Oricket

Figura 55 - Página do cardápio do bar

A página de cardápio do bar ilustra reproduz fielmente aquele que estará no bar. O objetivo de manter o mesmo leiaute e formatação é não surpreender o cliente que tiver se interessado por algum produto e se dirigido ao bar. 


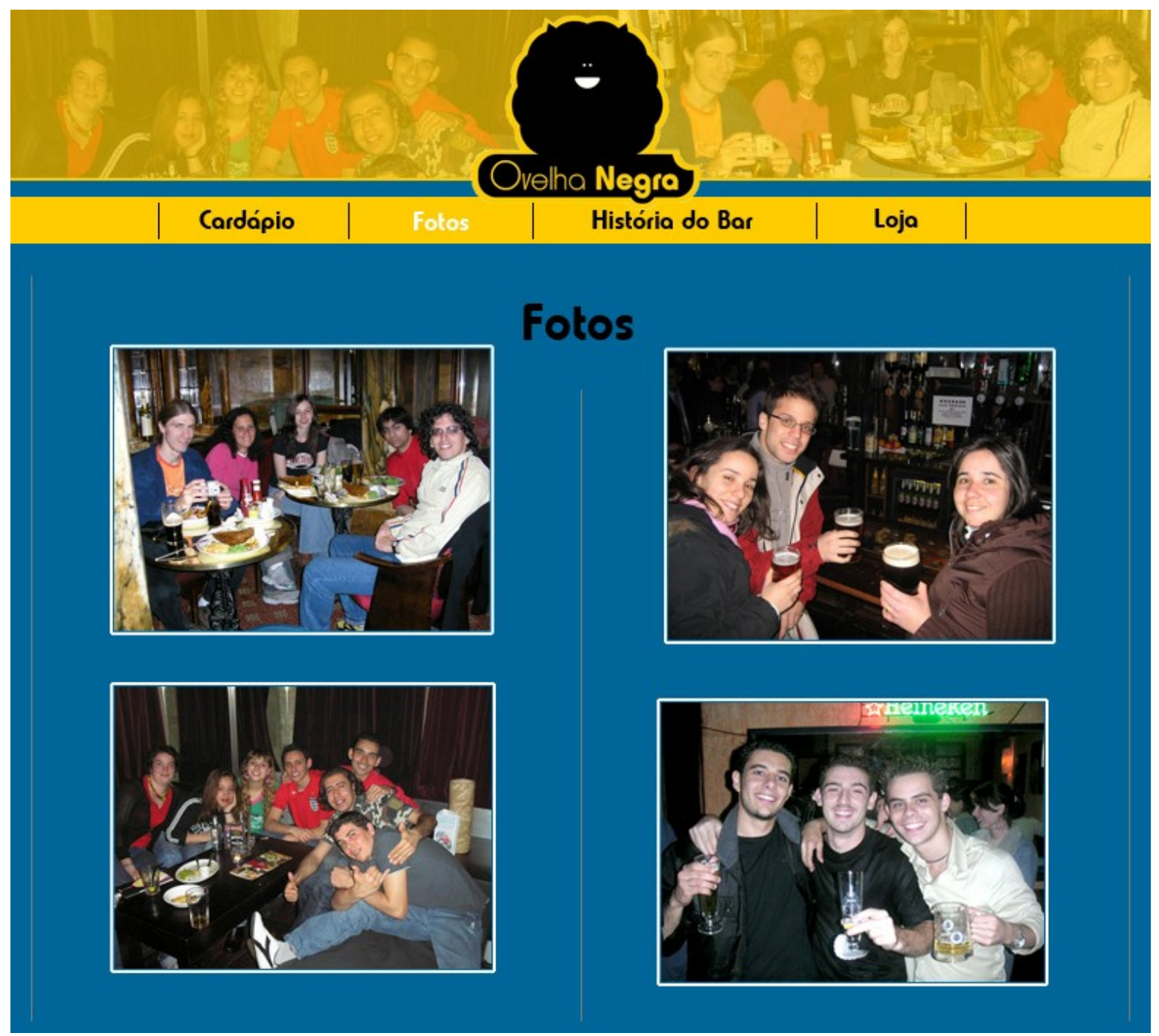

Figura 56 - Página de fotos do bar 


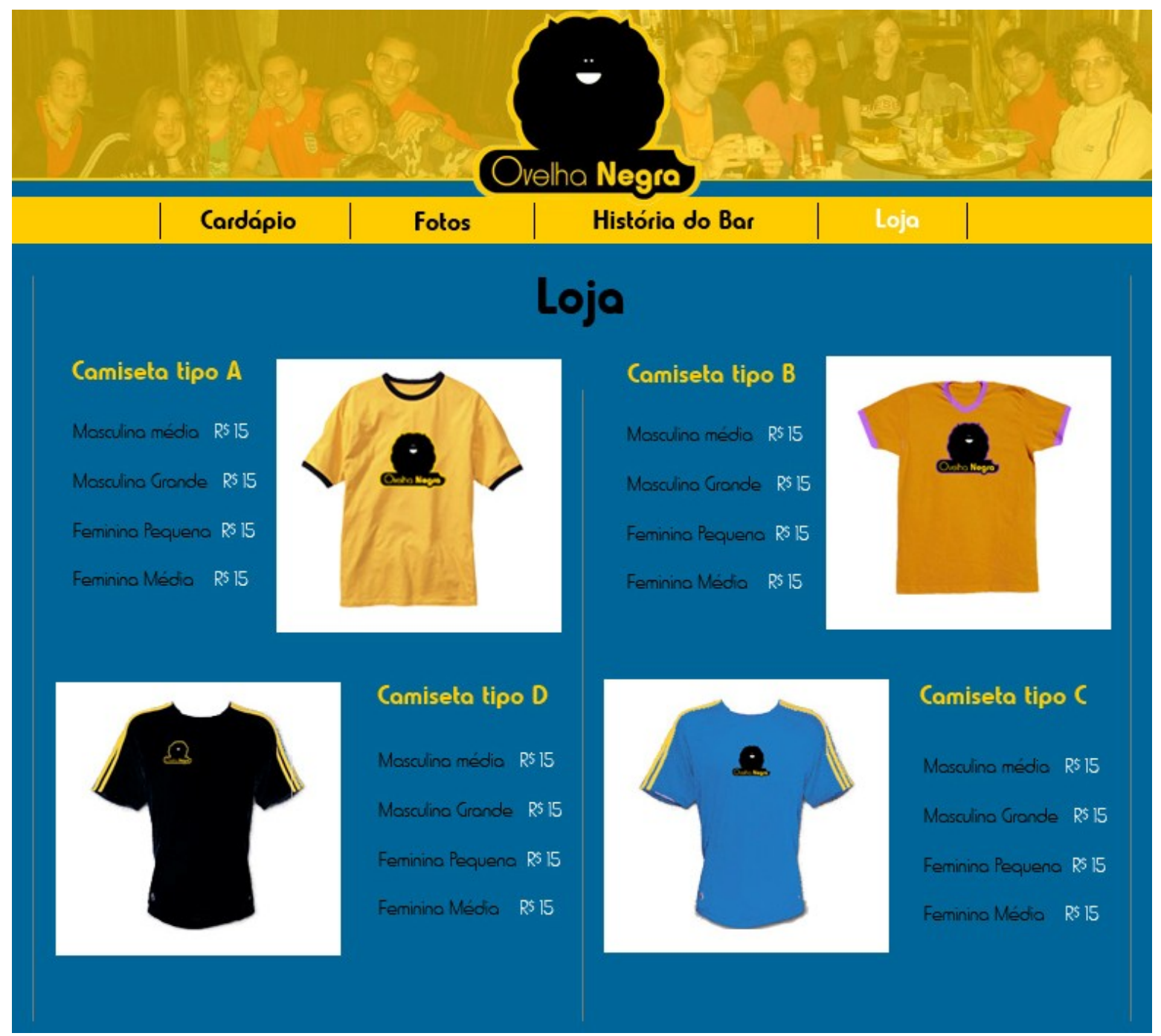

Figura 57 - Loja virtual do bar 


\section{8 - Definição do Padrão Cromático}

\section{Cores Principais}

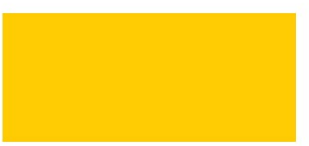

C: 1 M: 19 Y: 100 K: 0

R: 255 G: 203 B: 5

\section{Cores Auxiliares}

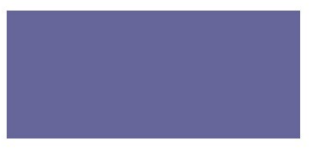

C: 69 M: 64 Y: 16 K: 1

R: 102 G: 102 B: 153

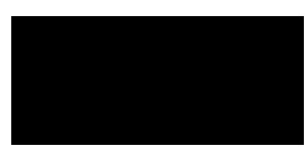

C: 75 M: 68 Y: 67 K: 90

R: 0 G: 0 B: 0

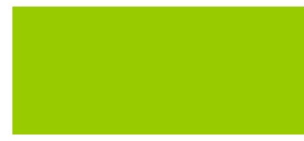

C: 45 M: 0 Y: 100 K: 0

R: 153 G: 204 B: 0

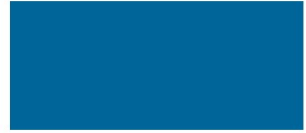

C: 93 M: 58 Y: 18 K: 2

R: 0 G: 102 B: 153

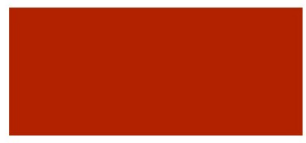

C: 69 M: $64 \mathbf{Y : ~} 16 \mathbf{K}: 1$

O padrão cromático da identidade Visual leva em consideração os requisitos de modernidade e influências do universo do grafite. As cores são fortes e diversificadas. No caso das cores principais que compõem a marca, há o fator adicional de serem as cores duas principais referências da marca: o produto do bar, a cerveja; e o símbolo do bar, a ovelha negra. Outro fato que sustenta essa escolha é a existência na natureza de vários casos dessa combinação de cores. Por exemplo: abelhas, pássaros, flores. Trata-se por isso de uma combinação muito usada no design de carros, acessórios esportivos, sinais de trânsito e vestimentas. 


\section{9 - Definição do Padrão Tipográfico}

Marca \& Institucional

Hammer Thin

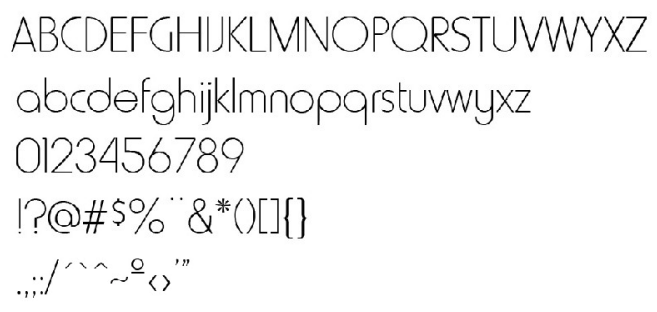

Hammer Fat

$$
\begin{aligned}
& \text { ABCDEFGHIJKLMNOPQRSTUVWYXZ } \\
& \text { abcdefghijkImnopqrstuvwyxz } \\
& 0123456789 \\
& \text { !?@\#\$\%“**()[] }\{\} \\
& \text {.,;:/ }{ }^{\cdots \sim} \sim<>"
\end{aligned}
$$

Institucional Auxiliar

\section{Hot Pizza}

Arial

\section{ABCDEFGHIJKMWOPQRSTUVWYXZ abcdefghijklmnopqrstuvwyxz 0123456789 \\ 1?@\#\$\% \&*0 . $; \%$ / <>}

\section{ABCDEFGHIJKLMNOPQRSTUVWYXZ abcdefghijklmnopqrstuvwyxz \\ 0123456789 \\ !?@\#\$\%"**()[\{\} \\ ,,,$: I^{\prime \wedge} \sim 0<>" \prime$}

O padrão tipográfico se apóia no requisito de uma idéia ao mesmo tempo moderna e sofisticada. A família Hammer apresenta essas duas características. É uma fonte alta e com muitas curvas, isso dá a ela um porte elegante e ao mesmo tempo arrojado. Sua versão Fat completa esse conceito de modernidade pois a torna mais pesada, fazendo referência ao peso das linhas dos desenhos do grafite. 


\section{4 - Produtos Finais}

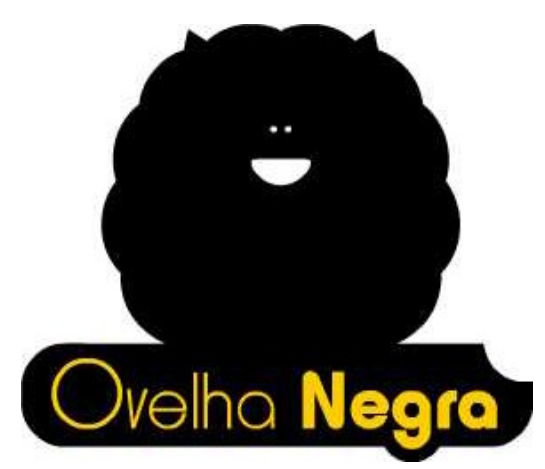

Figura 58 - Marca final

A marca cumpriu os requisitos levantados. Ela conseguiu unir de forma harmoniosa os aspectos de modernidade e sofisticação. O primeiro é atribuído pelo estilo das feições da ovelha, um estilo que remete a desenhos animados e ao universo do grafite; as cores também completam esse aspecto de modernidade, pois fazem uma combinação forte e muito utilizada na moda nos dias atuais. O segundo aspecto é definido pelo estilo elegante da tipografia empregada e pela simplicidade da marca, que contém apenas dois elementos: o conjunto da ovelha e da base da marca, e o logotipo abaixo.
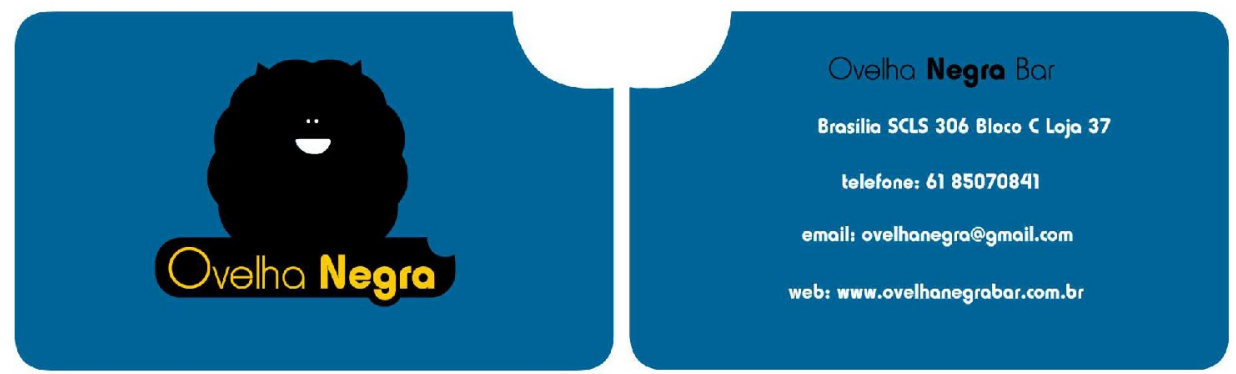

Figura 59 - Cartão final

O design final do cartão cumpre bem os requisitos do projeto. A marca está bem destacada no centro da frente do cartão. As demais informações ficam todas localizadas no verso. O formato do cartão chama atenção para uma característica essencial da marca, o "corte" na quina superior direita. Isso chama a atenção do cliente e realça uma característica de estilo, que reforça a imagem da marca na cabeça dos clientes. 

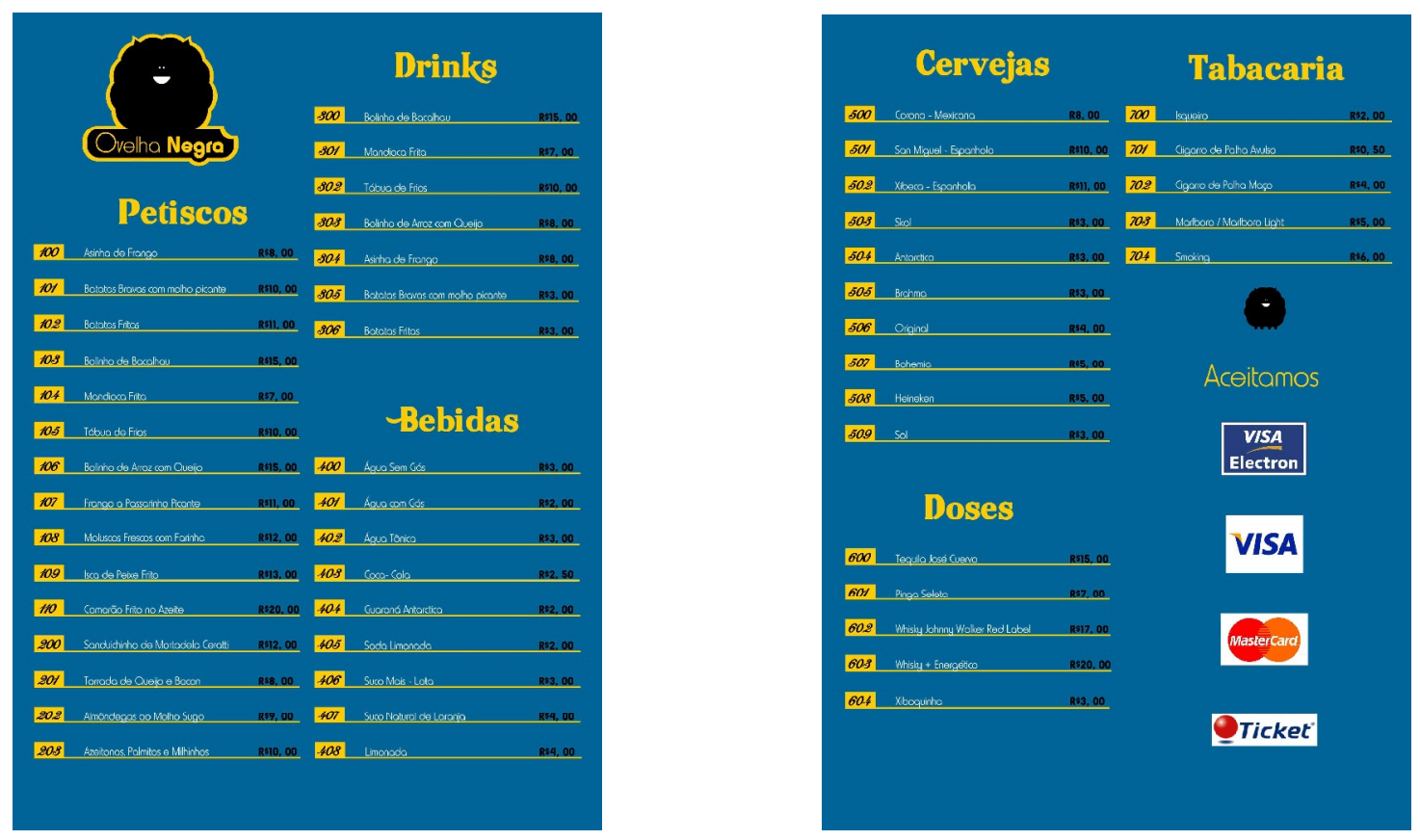

Figura 60 - Frente e verso da versão final do cardápio

O formato do cardápio, com 18 centímetros de largura por $25 \mathrm{~cm}$ de altura, foi planejado para poder ser impresso em uma folha de papel A4, facilitando e barateando sua impressão; ademais, foi especificado um formato menor que a folha inteira para que o cardápio pudesse ser segurado confortavelmente pelo cliente. Após impresso o cardápio deverá receber o acabamento chamado "laminação" em que duas folhas de plástico adesivo envolvem a folha, tornando-a rígida. Esse processo tem o objetivo de ampliar a vida útil do cardápio. A distribuição do seu conteúdo em apenas duas páginas favorece o atendimento no sentido que as informações estão mais acessíveis o que facilita a leitura dos números ou nomes pelo cliente aos garçons.

O design do cardápio segue padrão cromático estabelecido, utilizando as três cores principais escolhidas. A tipografia empregada tem por objetivo fazer referência a pizzarias o que reforça o objetivo do bar de estimular também a apreciação de tira-gostos e acepipes. 

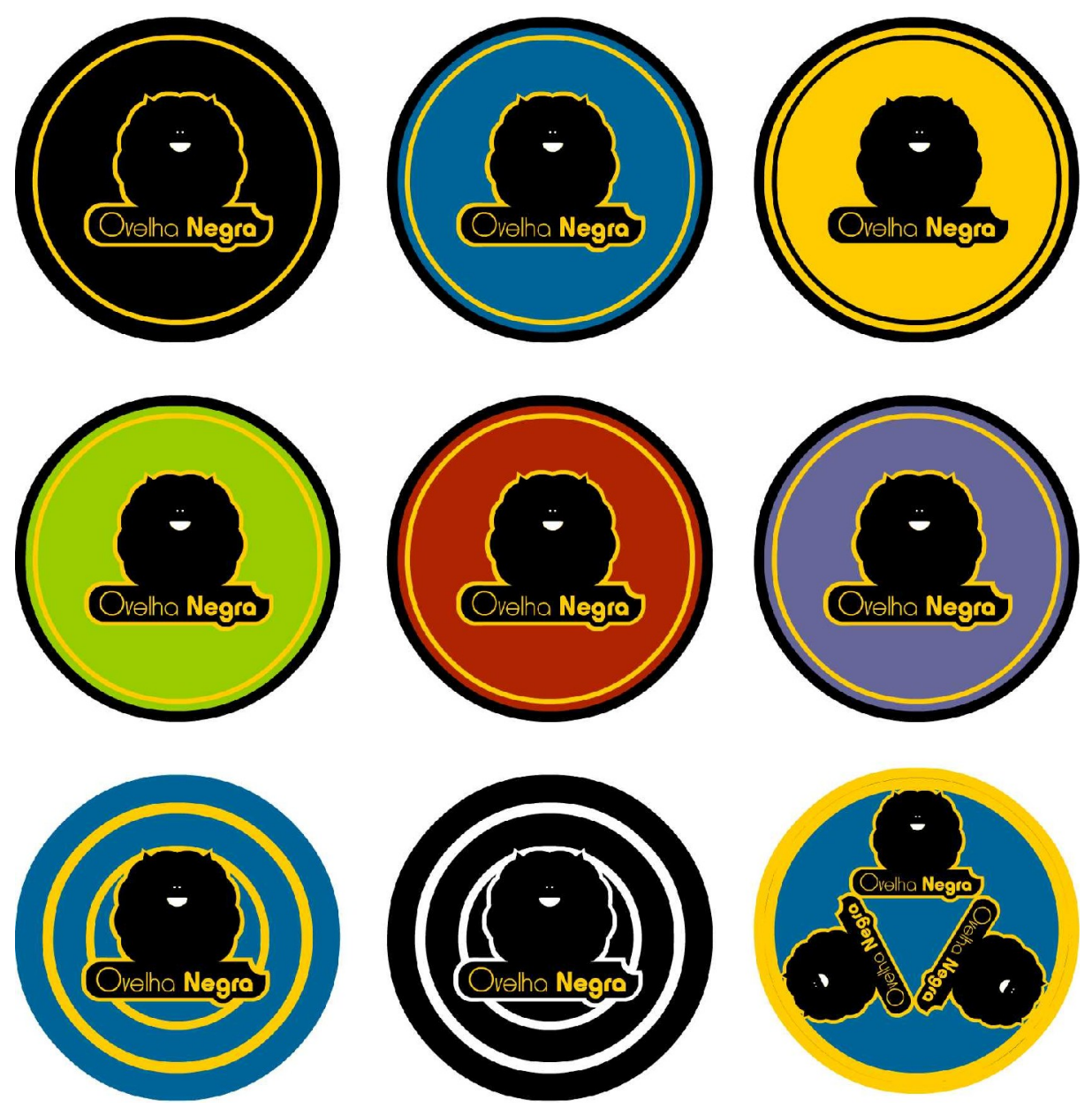

Figura 61 - Porta-copos versão final

Os porta-copos tem por objetivo estimular os clientes a levar esse produtos como lembrança do bar. Dessa forma, foram planejadas várias versões, bastante coloridas que deixarão a sensação de que o cliente ainda não conhece todas as versões, estimulando-o a buscá-las e colecioná-las. 


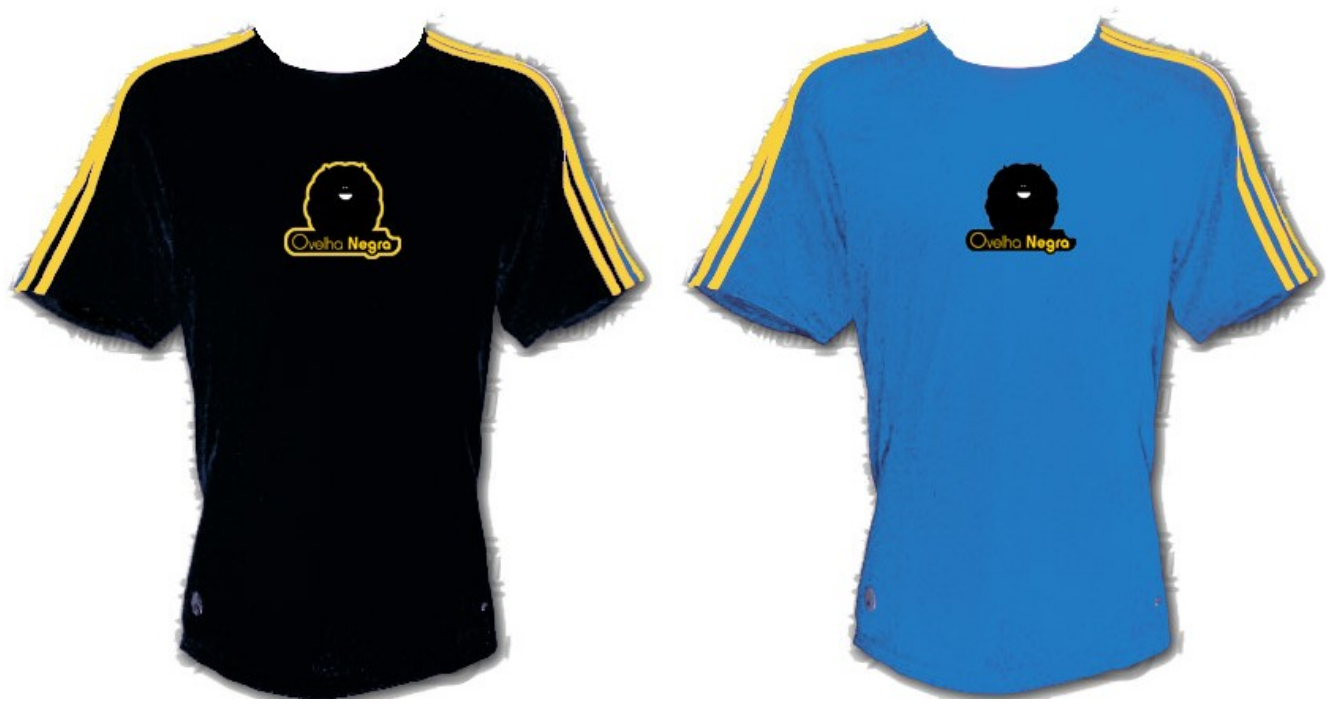

Figura 62 - Uniformes versão final

As camisetas definidas como uniforme do bar foram projetadas para serem usadas pelos funcionários e vendidas ao público na loja do bar. Além de aproximar o bar do público essa estratégia reforça a proposta do bar de ser jovem e moderno. As listras são um atrativo interessante para essas camisetas pois são um item desejado e que está na moda há bastante tempo. As cores são básicas, no sentido da moda, e podem combinar-se com quase qualquer outra cor. A marca destaca-se bem e além de divulgar o bar pode ser motivo de orgulho para o cliente.

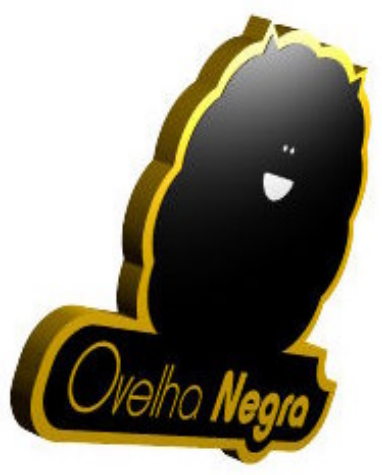

Figura 63 - Simulação de fachada

Foi feita uma simples simulação da fachada do bar utilizando a marca sem nenhuma adição nem modificação. A previsão é de uma chapa de compensado ou MDF de 20 a 40 $\mathrm{mm}$ moldada segundo os contornos da marca com um gabarito e adicionada de um adesivo de vinil impresso em gráfica com acabamento em verniz. 


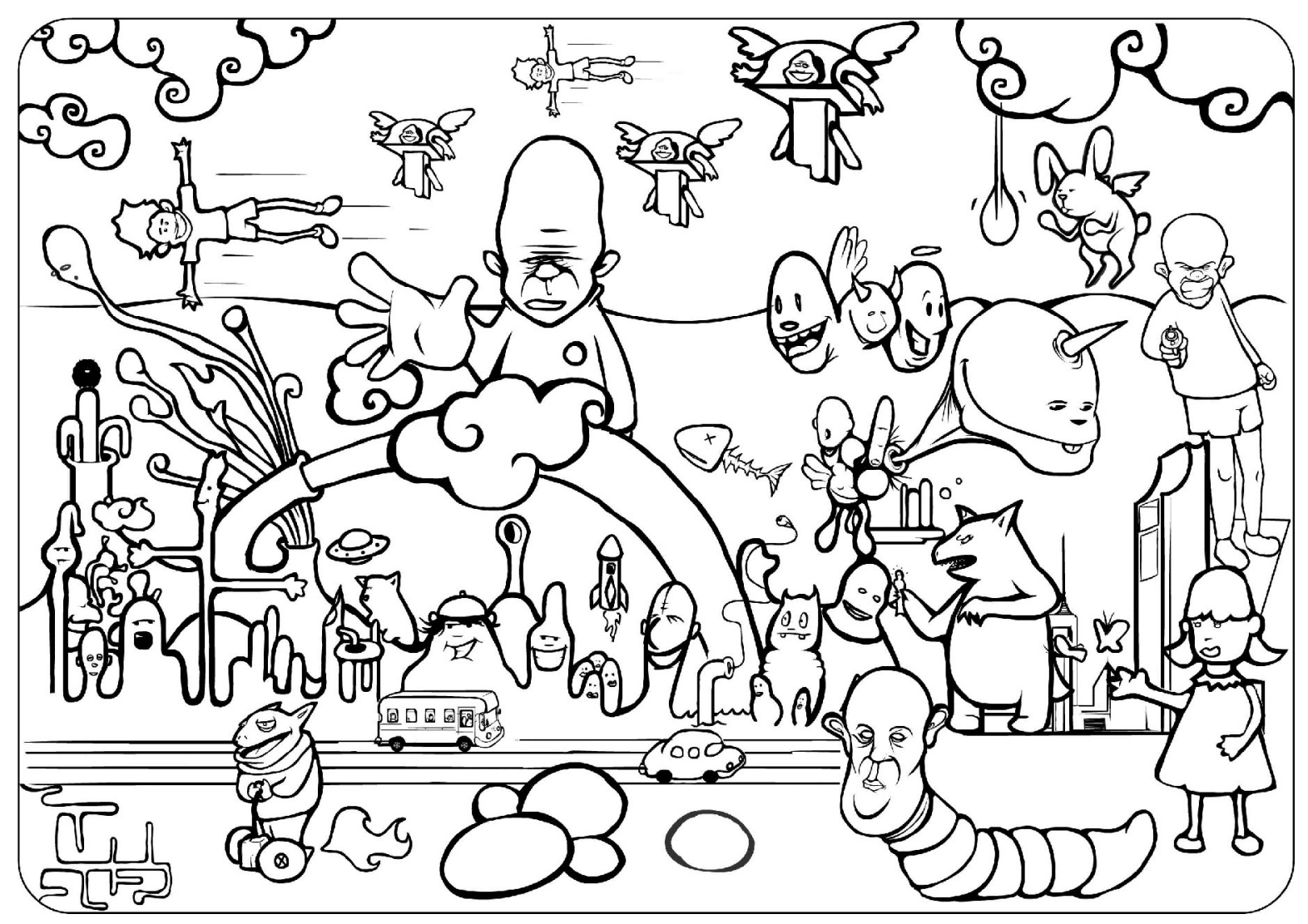

Figura 64 - Ilustração final para jogo americano e parede do bar

A ilustração do jogo americano e do bar é um item visual essencial para a identidade do bar. Será ela o item mais observado e por mais tempo pelos clientes, pois estará no jogo americano e na parede do bar. Ela é responsável pelo lado mais moderno do bar, tendo seus elementos influenciados diretamente pela linguagem do grafite. A forma como ela se apresenta define bem os objetivos e requisitos da marca, pois consegue ser caótica e harmônica, alternativa e sofisticada, simples e complexa, tudo ao mesmo tempo. Dessa forma ela é uma ótima lembrança que o cliente pode ter do bar. 


\section{6 - Conclusão}

Os objetivos do projeto foram plenamente alcançados. Todos os produtos foram definidos com sucesso, de acordo com o estilo da marca definido ao longo do processo. As técnicas utilizadas e o método seguido foram frutos da aprendizagem de cinco anos no curso de Desenho Industrial. Por ser um projeto de demanda real, um retorno importante ainda pode ser conseguido. Apesar disso, como parte desse processo, o designer também tem a responsabilidade de avaliar o seu trabalho. Dentro dos critérios propostos e das limitações de tempo e comunicação com o demandante o resultado obtido foi bastante gratificante. 


\section{7 - Referências Bibliográficas}

HARVEY, Wilson. Diseño de Catálogos Y Folletos 3. 1.Ed. Gustavo Gili

RIBEIRO, Milton. Planejamento Visual Gráfico. 6.Ed. LGE

WENDPAP, Alex Jonatan. Manual de Identidade Visual da Faculdade de Informática da Universidade Federal de Santa Maria. UFSM. Disponível em:

$<$ http://WWW-usr.inf.ufsm.br/ pasin/idvisual/manual-600dpi.pdf $>$ Acesso em: 18 Jun. 2008. 


\section{Apêndice A - Análise detalhada do conteúdo dos sites}

Le Mouton Noir Café Bistrô

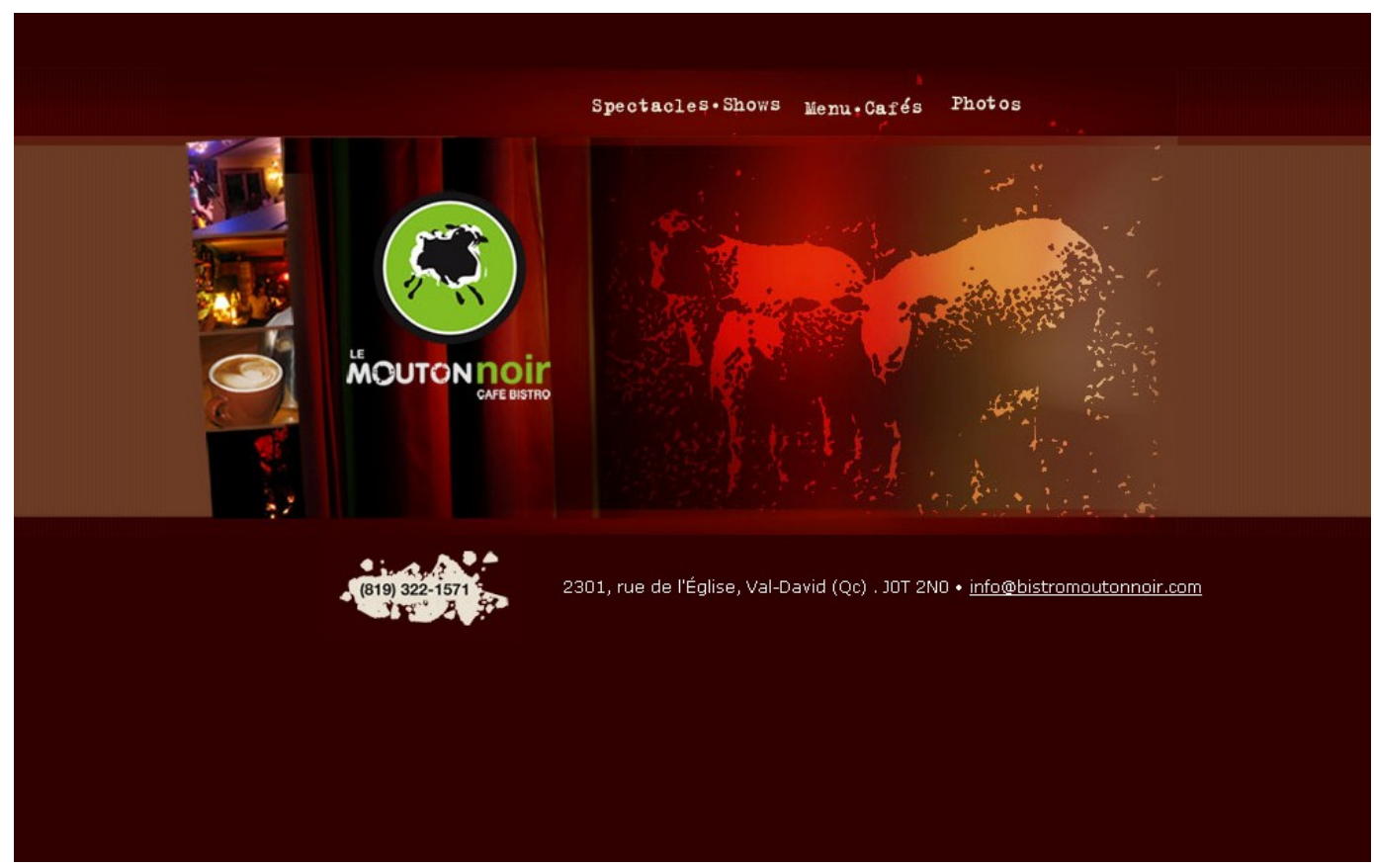

- Na página inicial : endereço, telefone e email.

- Novidades e espetáculos próximos.

- Menus por pratos de cada dia e cafés.

- Fotos de clientes do bistrô. 
The Black Sheep Pub (EUA)

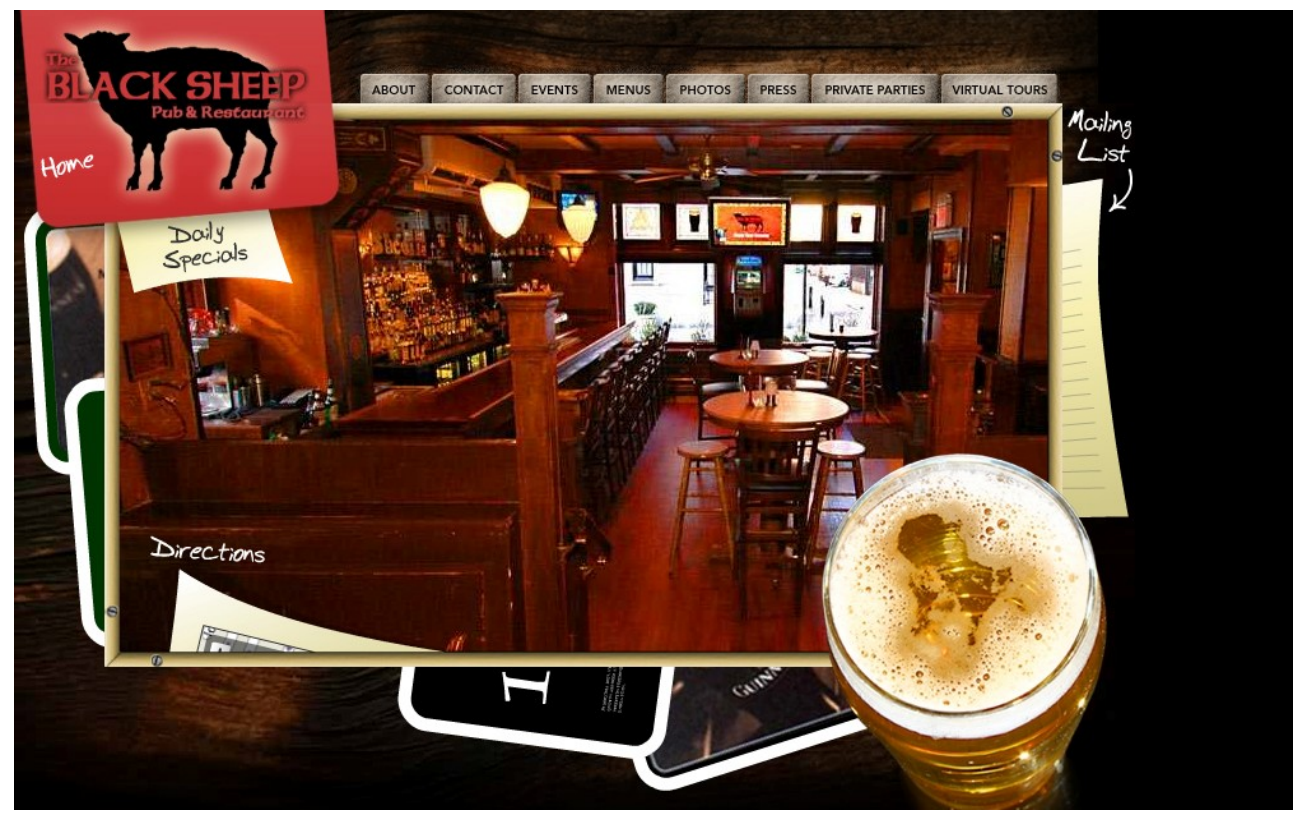

- Pratos e promoções especiais do dia

- Endereço e mapa mostrando como chegar no local.

- Página com fotos do lugar e informações sobre a proposta do pub.

- Página de contatos em geral.

- Calendário com eventos programados.

- Acesso aos menus do pub separados por categoria.

- Fotos dos clientes em eventos, separadas por evento.

- Página com citações sobre o pub na imprensa.

- Informações sobre como contratar serviço de festa particular, com possíveis serviços, horários e preços.

- Visita virtual pelo pub. 


\section{The Black Sheep Pub (Inglaterra)}
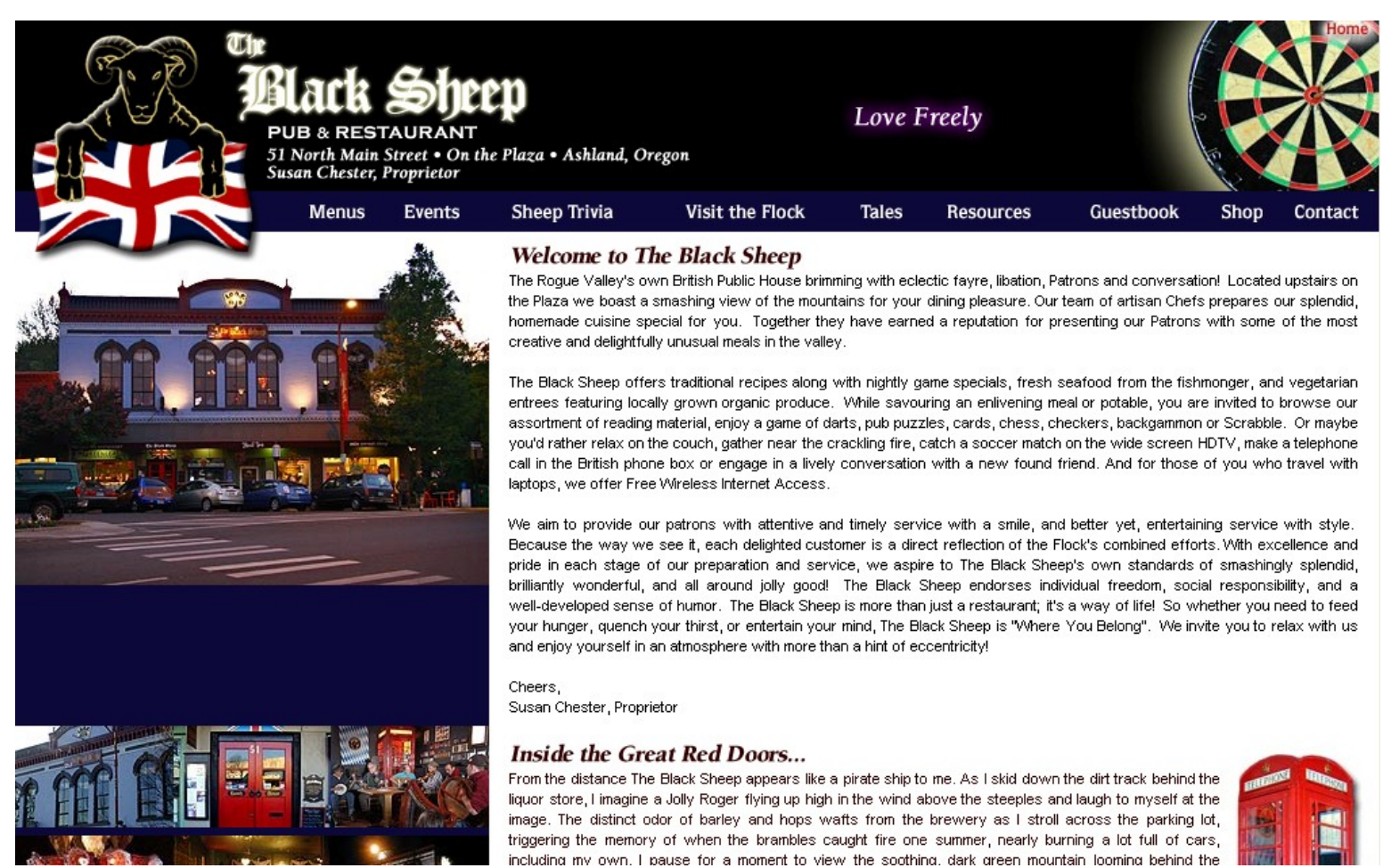

\section{Welcome to The Black Sheep}

The Rogue Valley's own British Public House brimming with eclectic fayre, libation, Patrons and conversation! Located upstairs on the Plaza we boast a smashing view of the mountains for your dining pleasure. Our team of artisan Chefs prepares our splendid, homenade cuisine special for you. Together they have earned a reputation for presenting our Patrons with some of the most creative and delighttully unusual meals in the valley.

The Elack Sheep offers traditional recipes along with nightly game specials, fresh seafood from the fishmonger, and vegetarian entrees featuring locally grown organic produce. While savouring an enlivening meal or potable, you are invited to browse our assortment of reading material, enjoy a game of darts, pub puzzles, cards, chess, checkers, backgamnon or Scrabble. Or maybe you'd rather relax on the couch, gather near the crackling fire, catch a soccer match on the wide screen HDTV, make a telephone call in the British phone box or engage in a lively conversation with a new found friend. And for those of you who travel with laptops, we offer Free Wireless Internet Access.

We aim to provide our patrons with attentive and timely service with a smile, and better yet, entertaining service with style. Because the way we see it, each delighted customer is a direct reflection of the Flock's combined efforts. With excellence and pride in each stage of our preparation and service, we aspire to The Elack Sheep's own standards of smashingly splendid, briliantly wonderful, and all around jolly goodl The Black Sheep endorses individual freedom, social responsibility, and well-developed sense of humor. The Black Sheep is more than just a restaurant, it's a way of lifel So whether you need to feed your hunger, quench your thirst, or entertain your mind, The Black Sheep is "Mhere You Belong". Whe invite vou to relax with us

Cheers,

Susan Chester, Proprietor

Inside the Great Red Doors...

From the distance The Elack Sheep appears like a pirate ship to me. As I skid down the dirt track behind the liquor store, I inagine a Jolly Roger flying up high in the wind above the steeples and laugh to myself at the image. The distinct odor of barley and hops wafts from the brewery as I stroll across the parking lot, triggering the memory of when the brambles caught fire one summer, nearly burning a lot full of cars, triggering the memory of when the brambles caught fire one summer, nearly burning a lot full of cars,

- Página inicial com endereço, telefone, horários e a história do pub.

- Acesso aos menus do pub.

- Página com mais histórias sobre o bar e itens antigos que figuram em seu interior, histórias sobre fraternidades, etc.

- Fotos de eventos marcantes do bar e clientes famosos.

- Depoimentos de como algumas pessoas conheceram o bar e suas experiências.

- Lista de sites favoritos.

- Livro de visitas com depoimentos mais informais.

- Loja virtual vendendo camisetas e casacos do bar.

- Página para escrever comentários que são enviados diretamente 
The Black Sheep (EUA) - Restaurante, mercado.

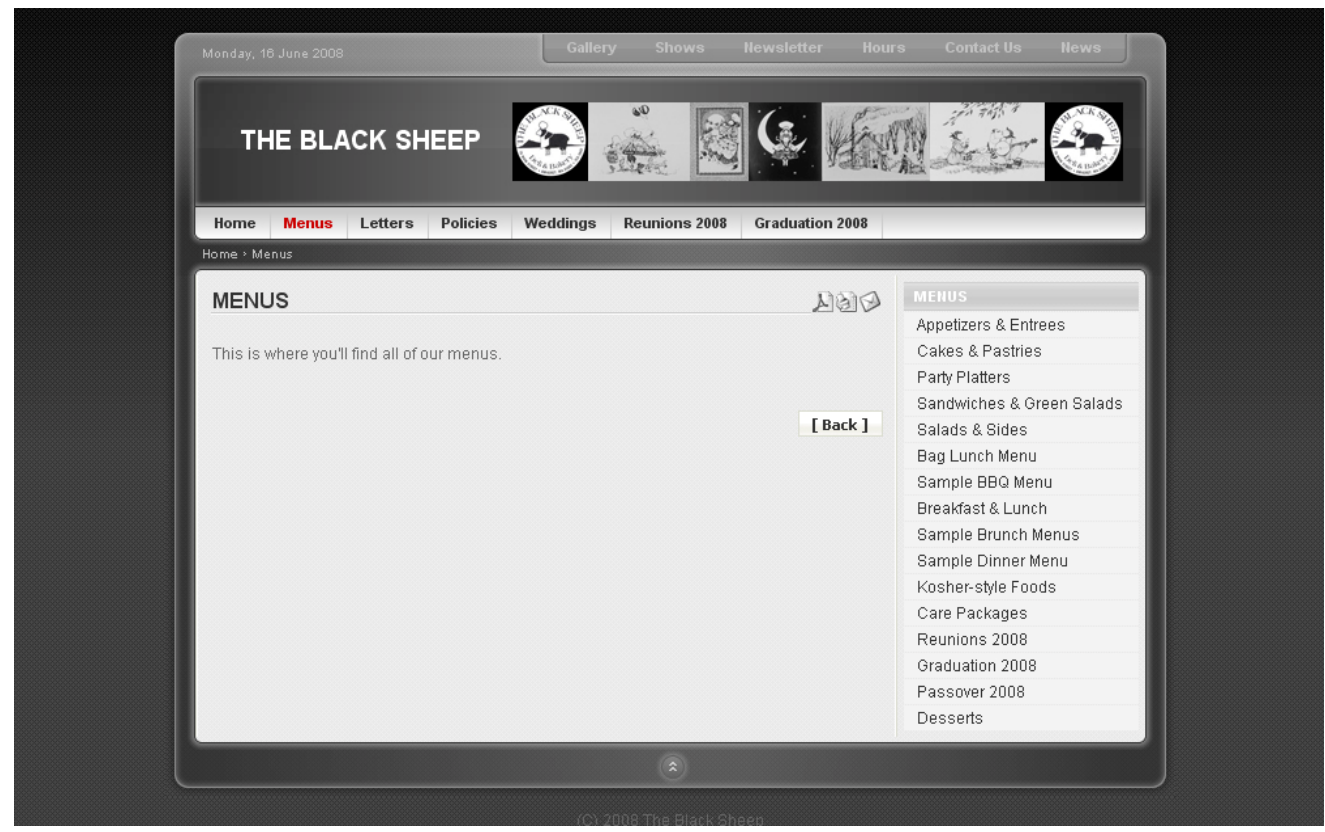

- Acesso a todos os menus com preços em PDF.

- Galeria de fotos.

- Página de novidades.

- Páginas explicando cada serviço de buffet.

- Página com próximos eventos. 
Black Sheep Bistrô (EUA)

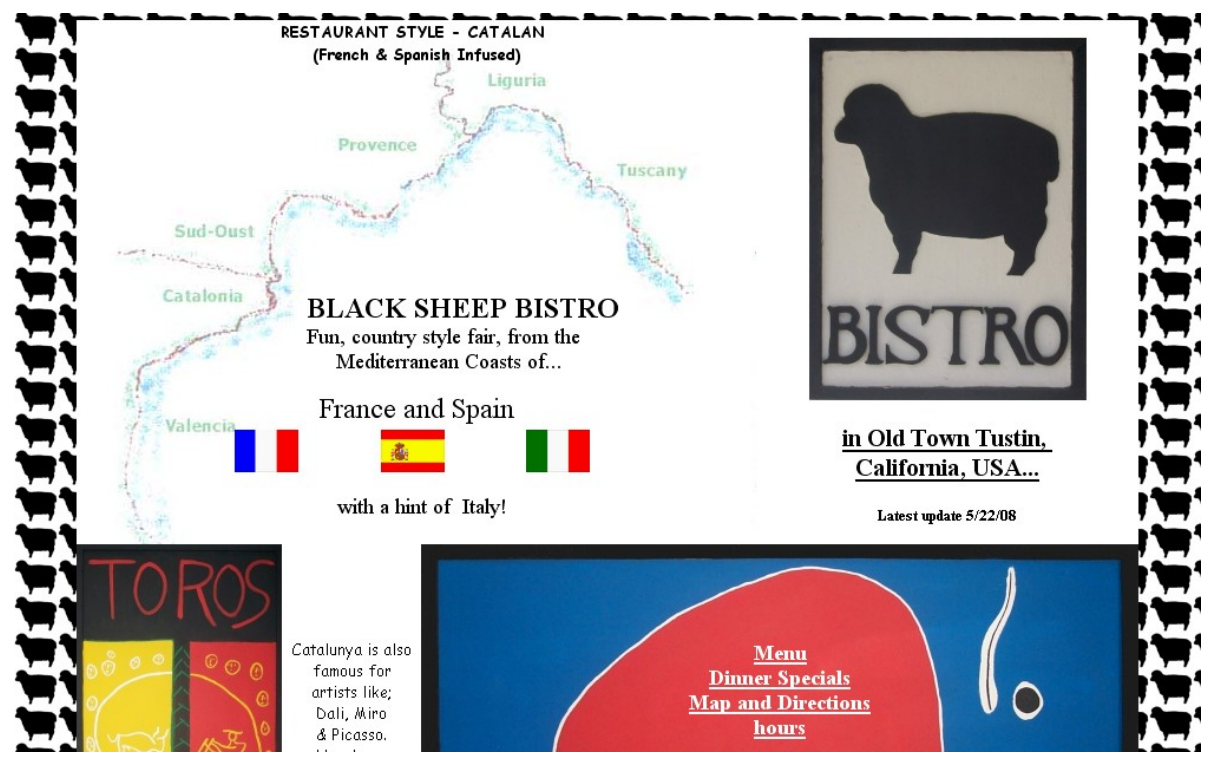

- Menus com preços.

- Lista de pratos especiais.

- Horários de abertura.

- Endereço e mapa de como chegar. 


\section{Bar do Calaf (Cozinha Catalã)}

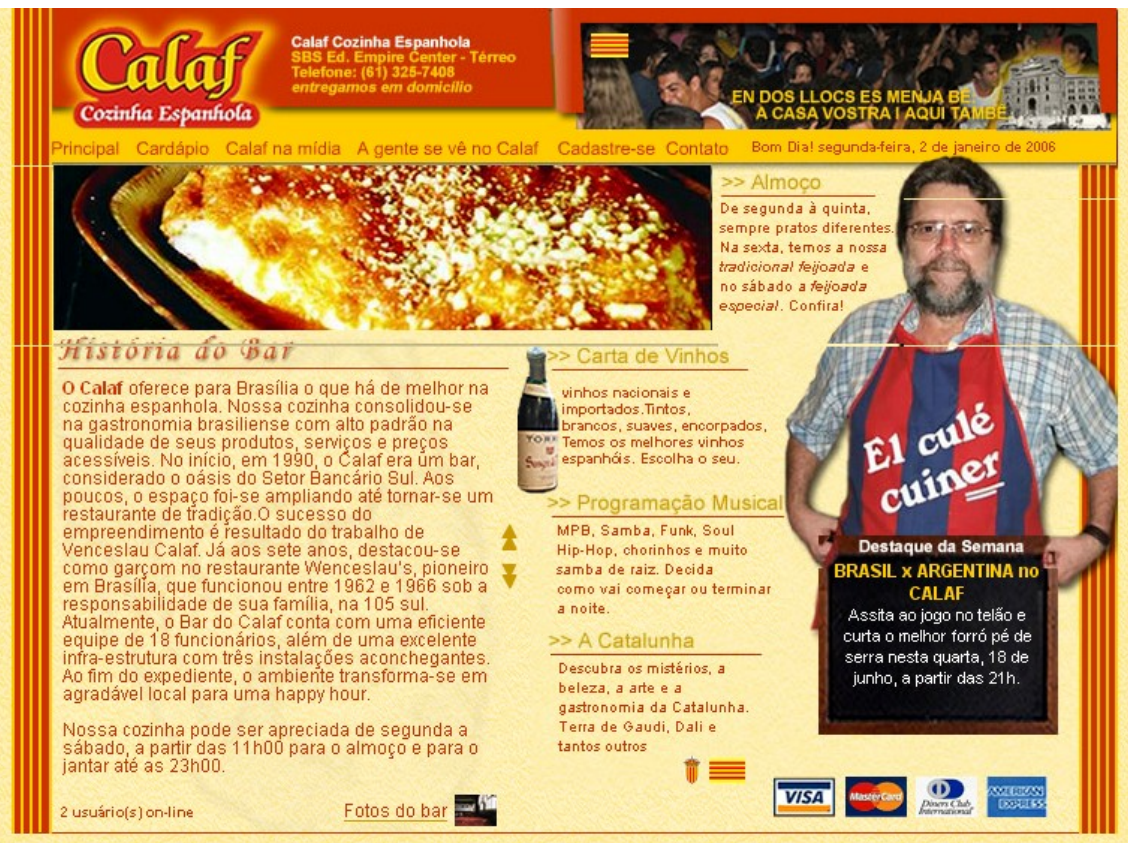

- História do bar.

- Carta de vinhos por nacionalidade com preços.

- Cardápio com preços, pratos especiais e receitas.

- Programação musical com calendário.

- Página com informações sobre a região da Catalunha.

- Cardápio completo com todos os pratos servidos por categoria.

- Página com citações do estabelecimento na imprensa.

- Galeria de fotos de clientes no bar.

- Página de cadastro para recebimento de emails e lista de aniversariantes.

- Página para envio direto de mensagens. 
Bar do Juarez (São Paulo)

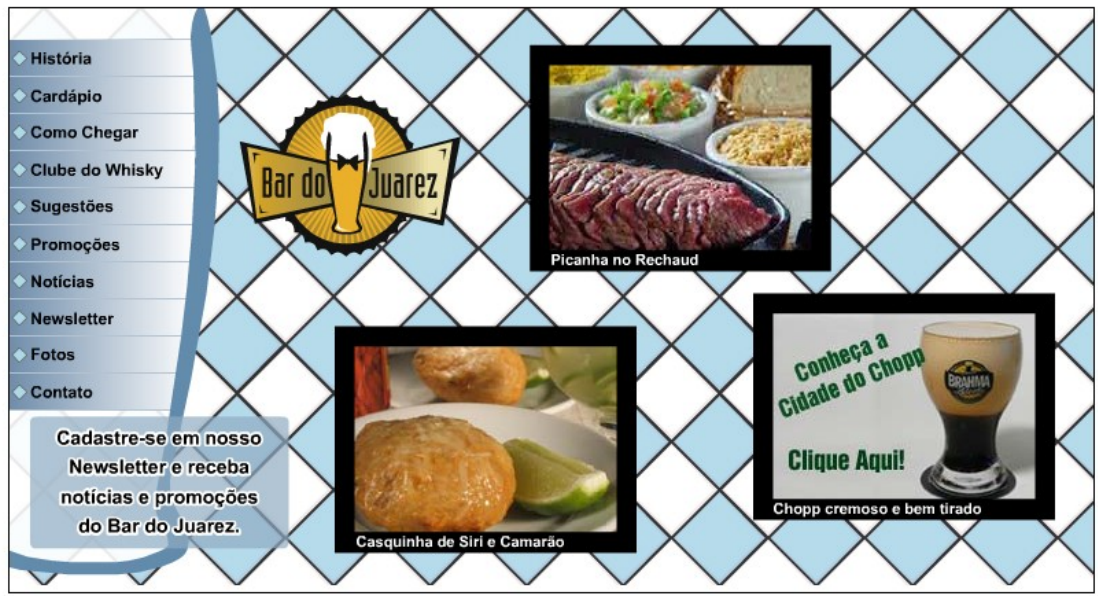

- História do bar.

- Cardápio sem preços.

- Endereço e como chegar.

- Página para postar sugestões.

- Novidades do bar.

- Promoções novas.

- Página de cadastro na newsletter.

- Notícias sobre produtos.

- Fotos de eventos no bar. 


\section{Bar Pingüim (Ribeirão Preto)}

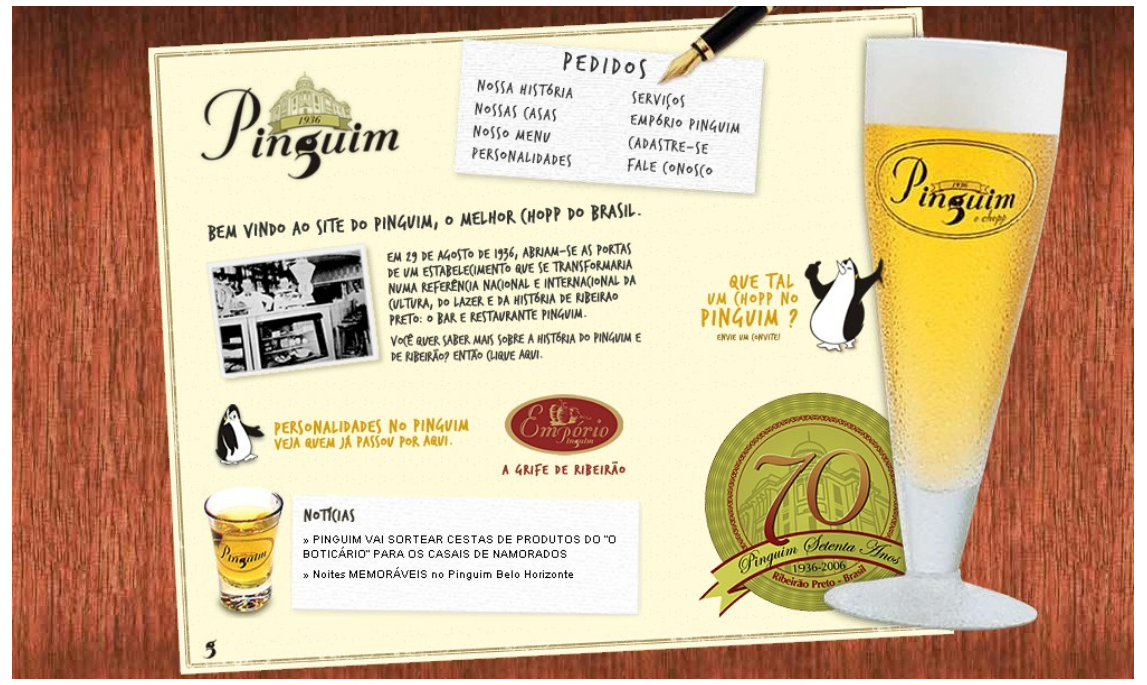

- Página inicial com últimas notícias.

- Lista de personalidades que freqüentam ou já freqüentaram o bar, com fotos.

- Página informando sobre a loja do bar.

- História do bar.

- Lista de cidades onda há filiais.

- Menu por categorias sem preços.

- Lista de serviços que o bar presta, como salão de festas, etc.

- Cadastro de clientes para recebimento de newsletter.

- Página para envio direto de mensagem. 
Ovella Negra (Espanha)
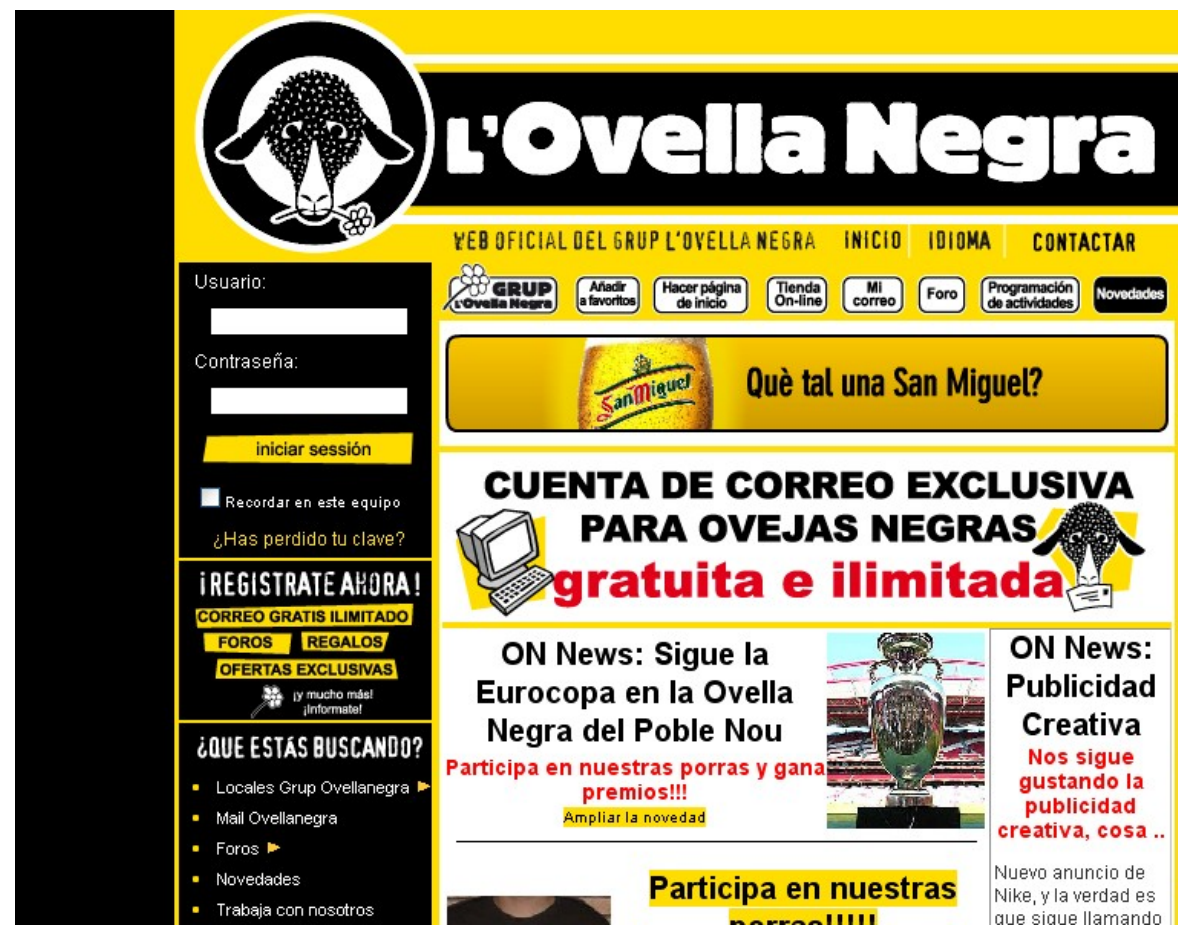

YEB OFICIAL OEL GRUP L'OVELLANEGRA INICIO IOIOMA CONTACTAR

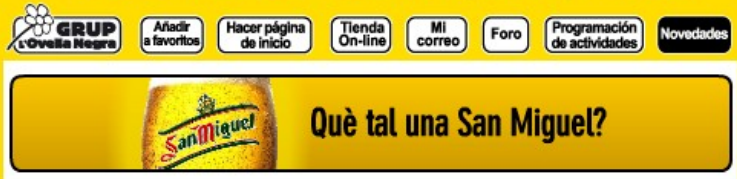

CUENTA DE CORREO EXCLUSIVA

Recordar en este equipo

Has perdido tu clave?

IREGISTRATE AHORA COREO GRAIIS LLIMITADO

OFERTAS EXCLUSIVAS

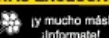

¿QUE ESTAS BUSCANDO?

Locales Grup Ovellanegra

Ovellaneg

Trabaja con nosotros

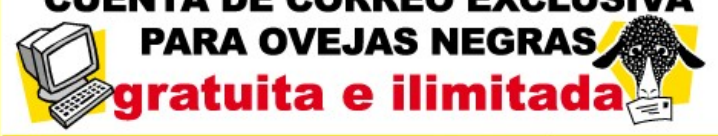

ON News: Sigue la Eurocopa en la Ovella Negra del Poble Nou Participa en nuestras porras y gana premios!!! Ampliar la novedad

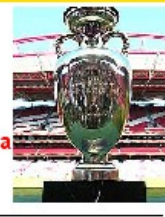

Participa en nuestras

Participa en nue

Nike, y la verdad es

ON News:

Publicidad

Creativa

Nos sigue

gustando la

gustando la

publicidad

creativa, cosa
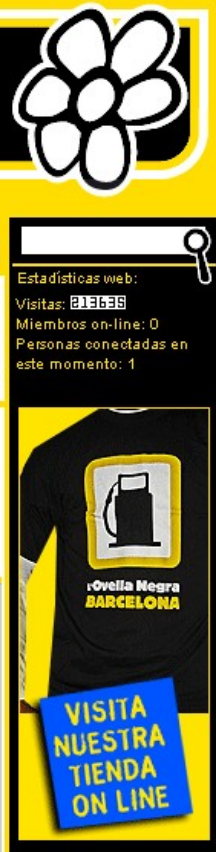
aue siaue llamando

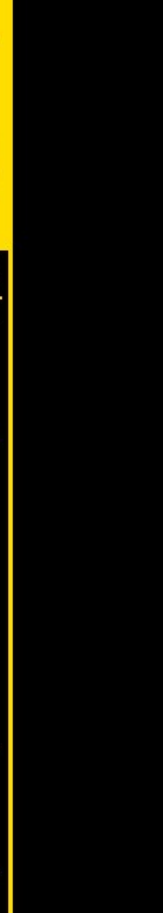

- Na página inicial : endereço, telefone e email.

- Novidades e espetáculos próximos.

- Menus por pratos de cada dia e cafés.

- Fotos de clientes do bistrô.

- Fórum de discussões.

- Página de notícias.

- Cadastro para recebimento de novidades. 
Apêndice B - Manual da marca para entrega ao cliente

Escala reduzida - original tamanho A4

\section{Manual de ldentidade Visual}

\section{Bor Ovelho Negro}




\section{Sumário}

\section{Apresentação}

Marca ............................................................. 2

Padrâo Cromático ............................................. 3

Padrão Tipográfico ........................................... 4

\section{Especificaçóes}

Tons de Cinza ............................................. 5

Negativo e Fundos Coloridos ............................6 6

Reduçóes ........................................................ 7

\section{Papelaria}

Cartão Corporativo .......................................... 8

Cardápio .................................................... 9

Porta-copo .................................................. 11

Jogo americano ........................................ 12

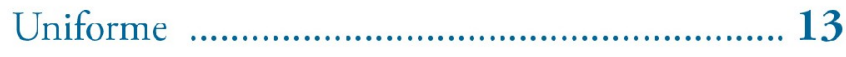

Ficha Técnica ...................................... 14 


\section{Apresentação}

A assinatura com a marca principal deve ser utilizada sempre que possível. Para os casos em que sua aplicaçáo compromete a aplicação ou é impossibilitada por qualquer fator externo, seráo empregadas as aplicaçóes alternativas previstas neste manual.

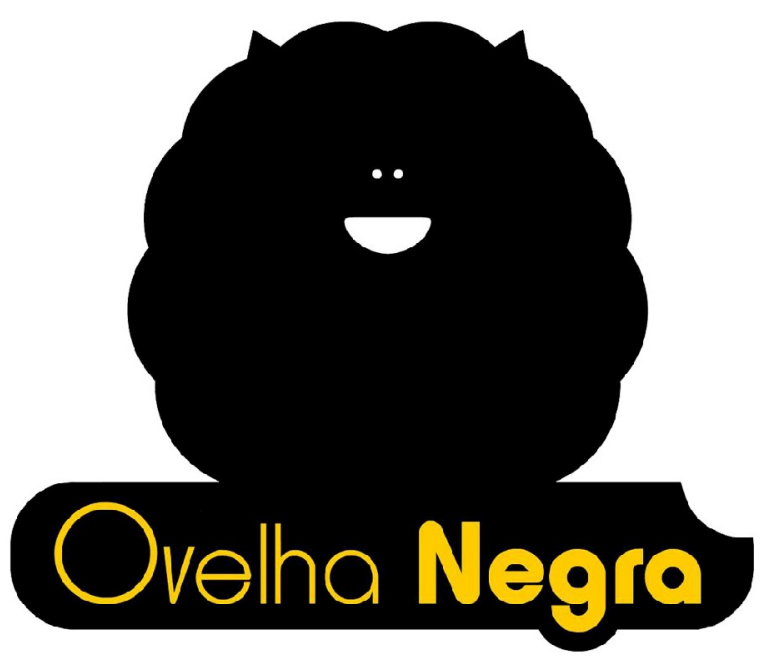

Versão principal

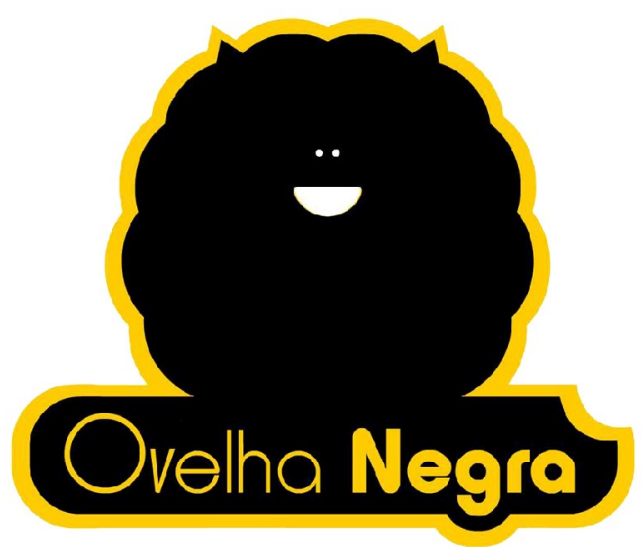

Versão para fundos escuros 


\section{Padráo Cromático}

Abaixo estáo representados os padrões cromáticos em duas escalas distintas: CMYK e RGB. A primeira será utilizada para todos os meios concretos e paupáveis obtidos por impressão a laser ou jato de tinta. Toda aplicação que requiser o envio a gráficas terá suas informaçóes de cores baseadas nessa escala. A escala RGB será empregada nos casos de utilizaçáo digital da marca. Quando empregada em televisores, computadores, internet ou qaulquer outro meio digital, essa escala será empregada.

A cor amarela é utilizada principalmente em referência à cor da cerveja. A sua combinaçáo com o preto, muito encontrada na natureza e em representaçóes gráficas, é uma mistura interessante que cumpriu com o propósito da marca de ser moderna e remeter ao ambiente de bar.

\section{Cores Principais}

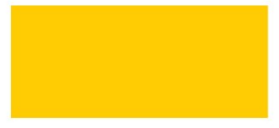

C: $1 \mathbf{M}: 19$ Y: $100 \mathbf{K}: 0$

R: 255 G: 203 B: 5

Cores Auxiliares

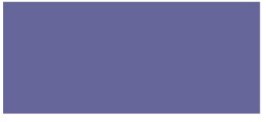

C: 69 M: 64 Y: 16 K: 1

R: 102 G: 102 B: 153

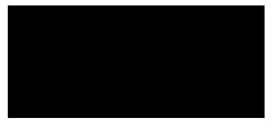

C: 75 M: 68 Y: 67 K: 90

R: 0 G: 0 B: 0

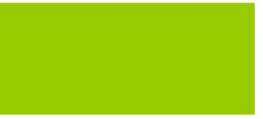

C: 45 M: 0 Y: 100 K: 0

R: 153 G: 204 B: 0

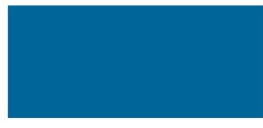

C: 93 M: 58 Y: 18 K: 2

R: 0 G: 102 B: 153

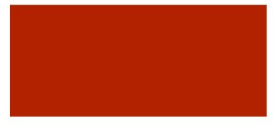

C: 69 M: 64 Y: 16 K: 1 


\section{Padrão Tipográfico}

A tipografia utilizada nas aplicaçóes da marca deverá obedecer as especificaçóes contidas neste manual. E de extrema importância que não seja utilizada nenhuma outra fonte que náo esteja listada entre as principais ou secundárias.

Foi escolhida a fonte Hammer para essa marca por se tratar de uma fonte năo serifada cujo entendimento se dá de forma mais direta. Trata-se de uma fonte com muitas curvas e que remete portanto à pelagem da ovelha. Por ser um tipo claro e direto, ela cumpre bem o objetivo de comunicar modernidade e autenticidade. A família auxiliar deve ser usada em textos quando necessário.

Marca \& Institucional

Hammer Thin

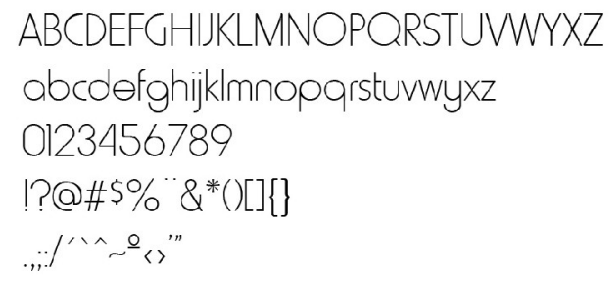

Hammer Fat

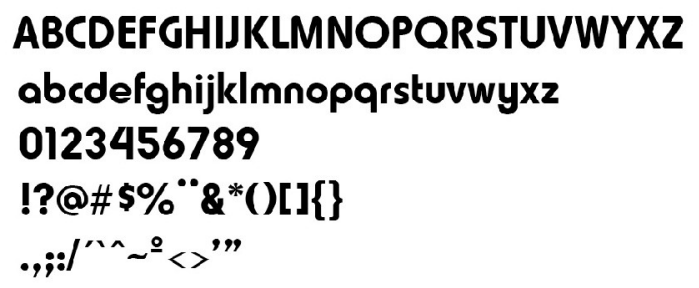

Institucional Auxiliar

Hot Pizza

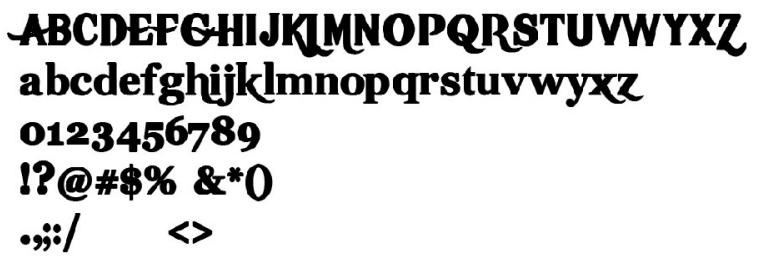

Arial

$$
\begin{aligned}
& \text { ABCDEFGHIJKLMNOPQRSTUVWYXZ } \\
& \text { abcdefghijkImnopqrstuvwyXz } \\
& 0123456789 \\
& \text { !?@\#\$\%" } \left.\&^{*}()[]\right\} \\
& .,: \text {, }^{\wedge} \sim 0<>" ”
\end{aligned}
$$




\section{Tons de Cinza/ P \& B}

A marca também poderá ser aplicada em tons de cinza, aplicação comumente utilizada em divulgaçóes que mereçam pouco aporte financeiro ou que não haja possibilidade de impressão colorida. Para eses casos há duas opçôes: uma em tons de cinza e outra em preto e branco.
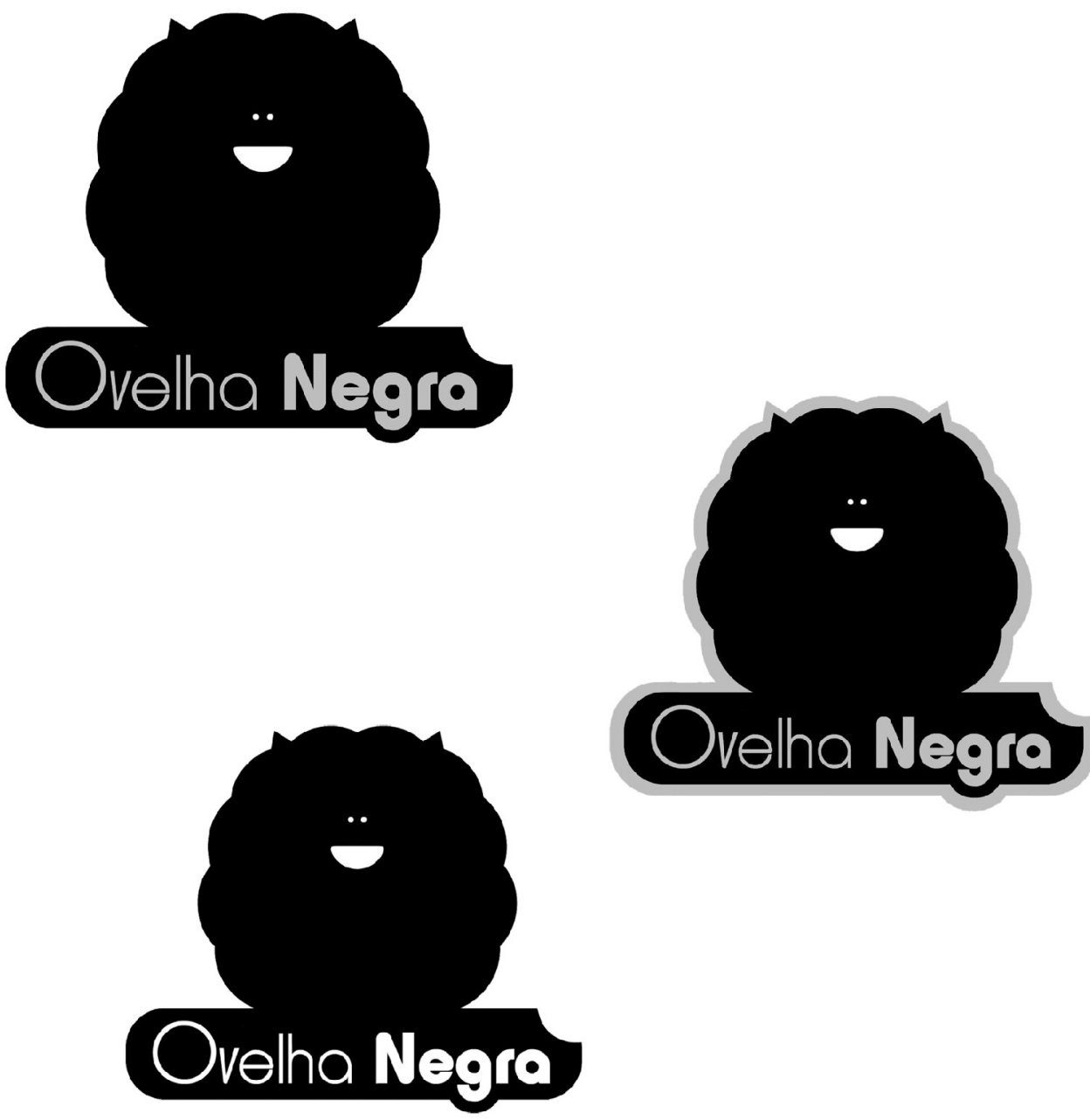

As marcas em tons de cinza utilizam somente a retícula preta a 30\% para a cor cinza que substitui o amarelo e a $90 \%$ para a cor preta em si. A versão preto-e-branco é projetada para casos de impressão em papel branco utilizando-se apenas a retícula preta a 90\%. 


\section{Negativo e Fundos Coloridos}

Para a utilização da marca em negativo, é indicada a utilização da versão com contorno da marca. Essa versão pode também ser utilizada em outros fundos, contanto que esses não sejam claros demais (com exceção do branco, que é permitido) e não sejam amareloas ou de cores próximas ao amarelo. Nesses casos deve ser utilizada a versão da marca sem contorno.
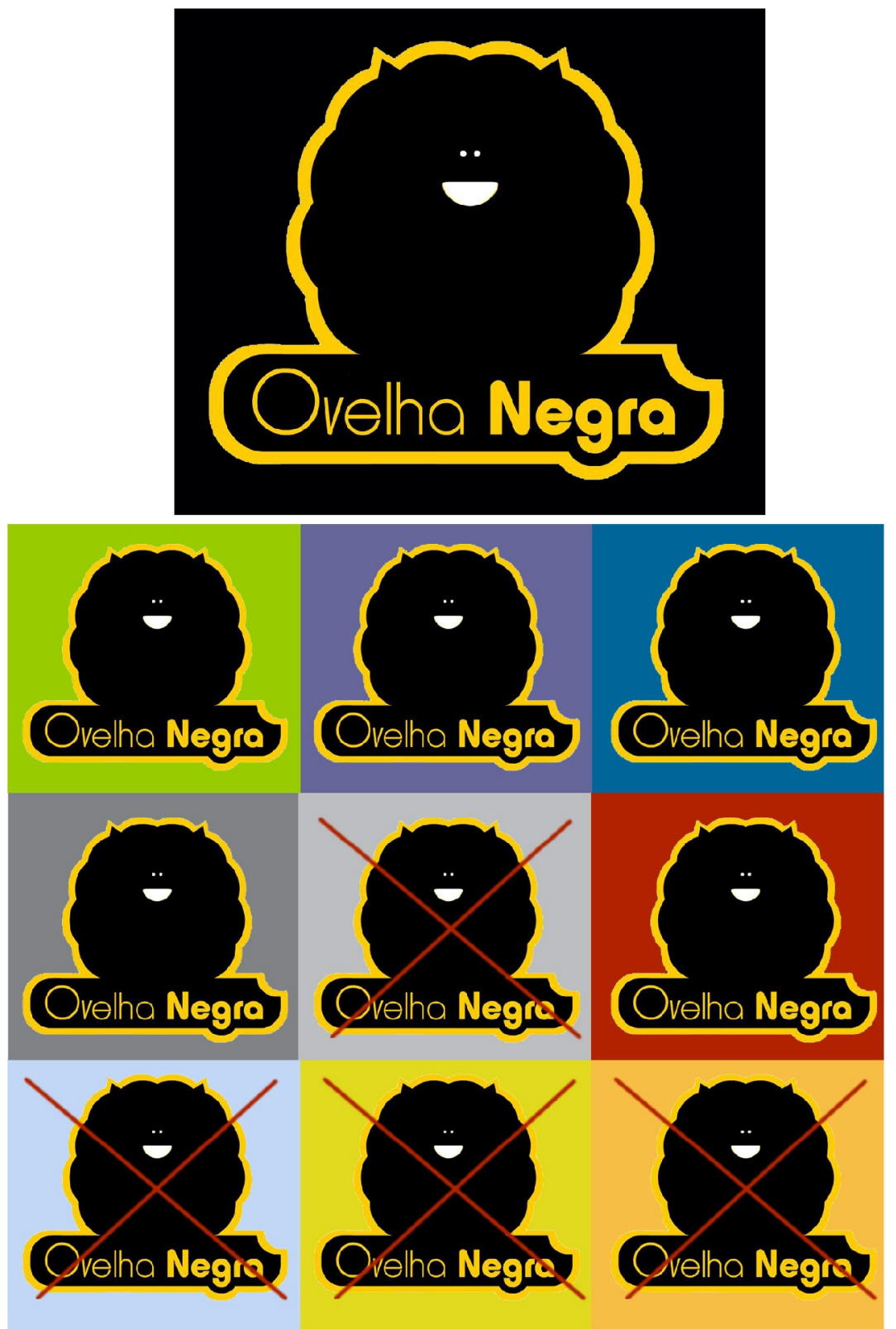


\section{Redução}

Para que a marca não perca a legibilidade e a leiturabilidade desejáveis, não poderá ser reduzida para mens de $2 \mathrm{~cm}$ de largura. Pega-se a largura como base pois é a medida de mais fácil medida. As proporçóes devem ser sempre mantidas. As especificaçóes de dimençôes mínimas para redução referem-se especialmente a casos em que seja necessário reduzir bastante a marca. Em geral, tratando de situaçóes ideais, recomenda-se que a marca náo seja reduzida a menos de quatro centímetros $(4 \mathrm{~cm})$ de largura.

Valores referentes à largura

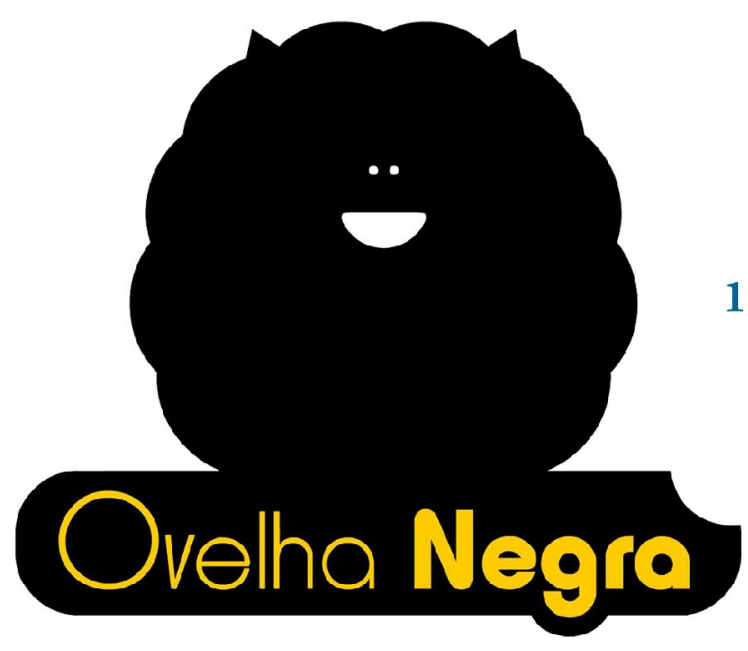

10 centímetros

7,5 centímetros
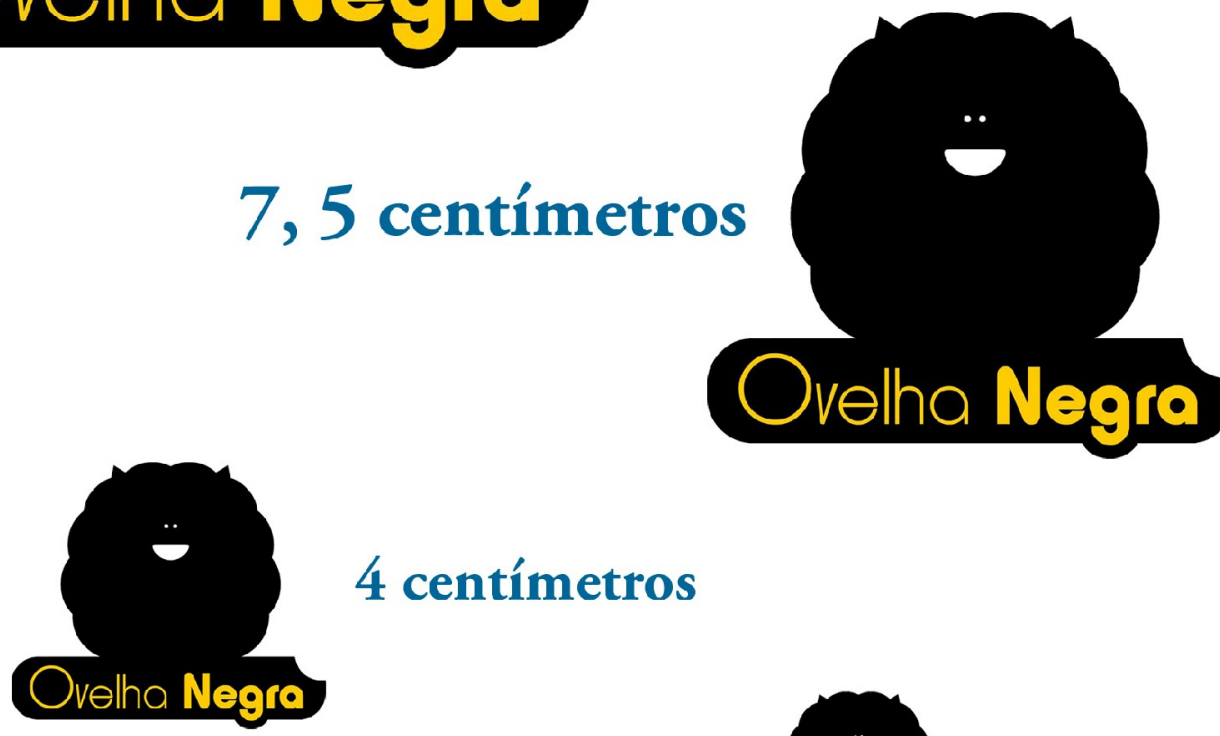

4 centímetros

3 centímetros

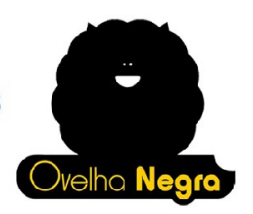

2 centímetios 


\section{Papelaria}

\section{Cartão Corporativo}

O cartáo corporativo do bar é responsável por passar a primeira impressão do estabelecimento àqueles que ainda não o conhecem. Por isso, para chamar a atenção do interessado aos diferenciais da marca, escolheu-se um formato náo usual que faz referência a uma característica peculiar da marca. O formato do cartão é arredondado e tem um corte no canto superior direito, assim como na marca. Ao fazer o pedido de impressão deve-se então ter o cuidado de esclarecer essas diferenças e pedir que seja confeccionada uma faca de corte especial.
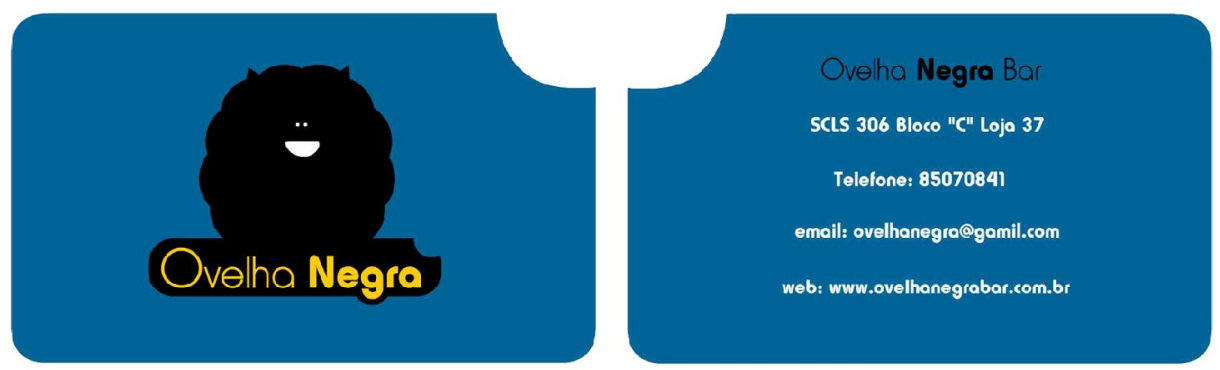

Caso não seja possível por qualquer motivo se obter esse formato do cartão, há a opçáo de uma versão retangular simples, mantendo as mesmas informaçôes e proporçôes. Essa versão porém só devcrá scr utilizada cm último caso.
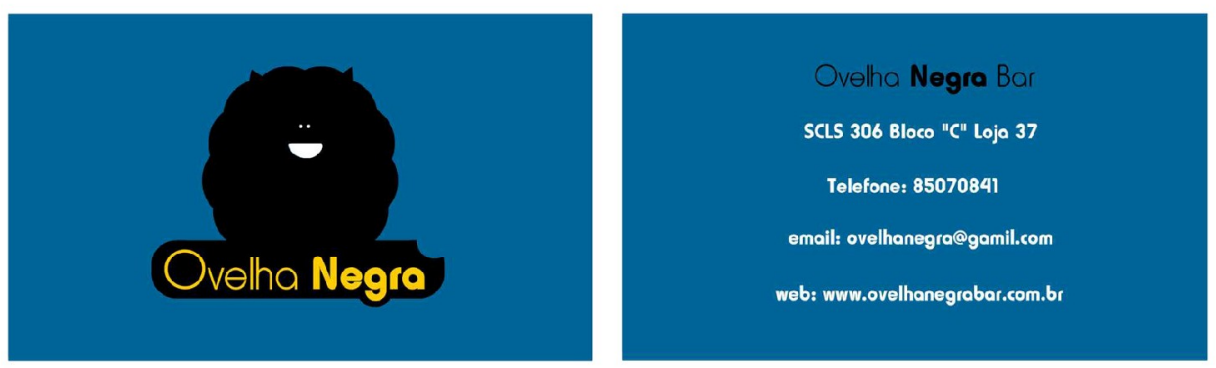


\section{Papelaria}

\section{Cardápio}

Estando representado aqui em escala 4/5, o cardápio terá o formato real de 18 centímetros de largura por 25 centímetros de altura. Será constiuído de uma só folha, estando seu conteúdo distribuído em frente e verso. As cores utilizadas sẫo as três principais e as fontes são Hammer thin e Hammer Fat e a auxiliar Hot Pizza.

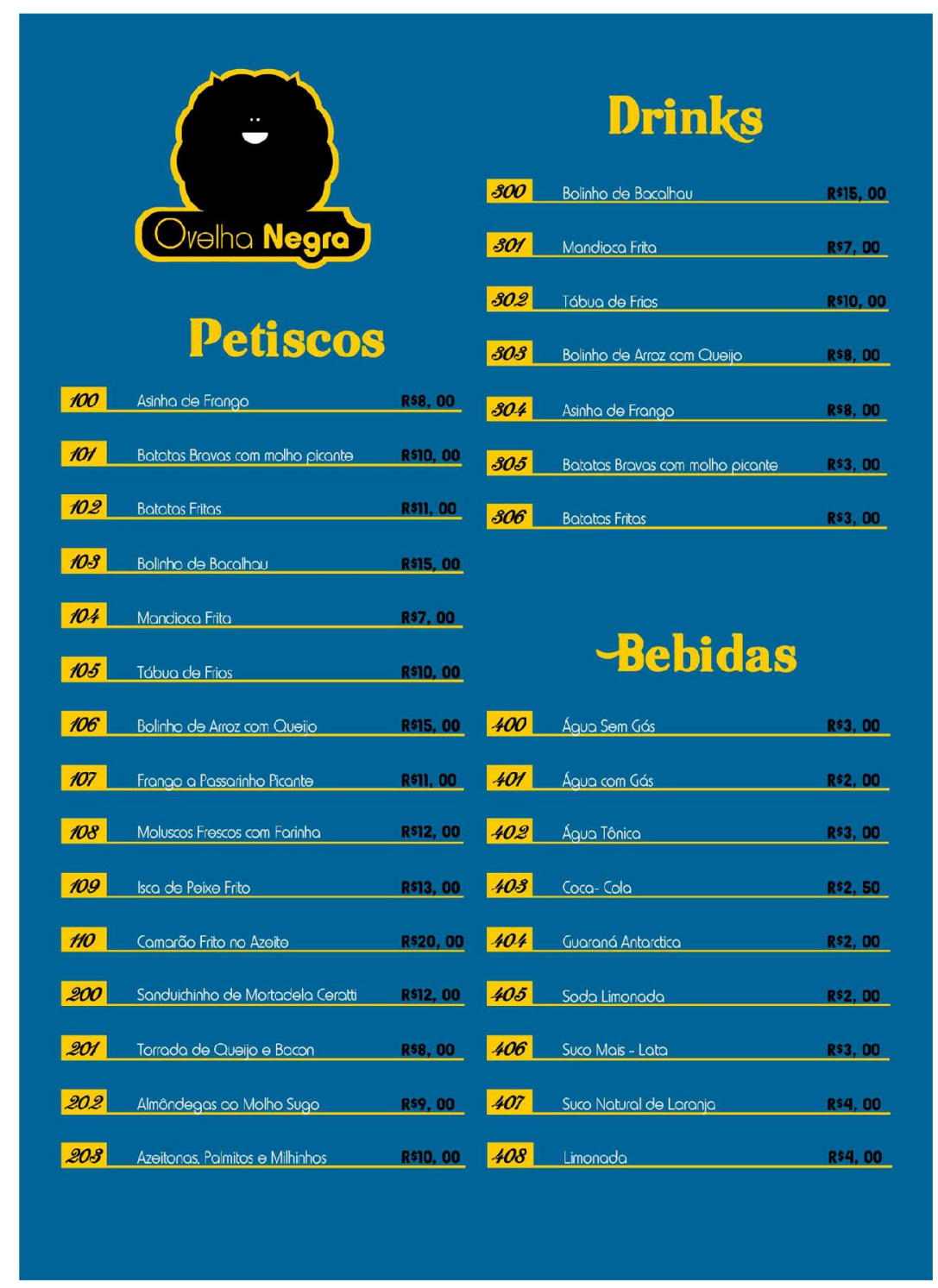

FRENTE 


\section{Papelaria}

\section{Cardápio}

Recomenda-se que o cardápio seja plastificado de forma a tornar-se rígido, evitando a sua rápida deterioraçáo e facilitando seu manuseio.

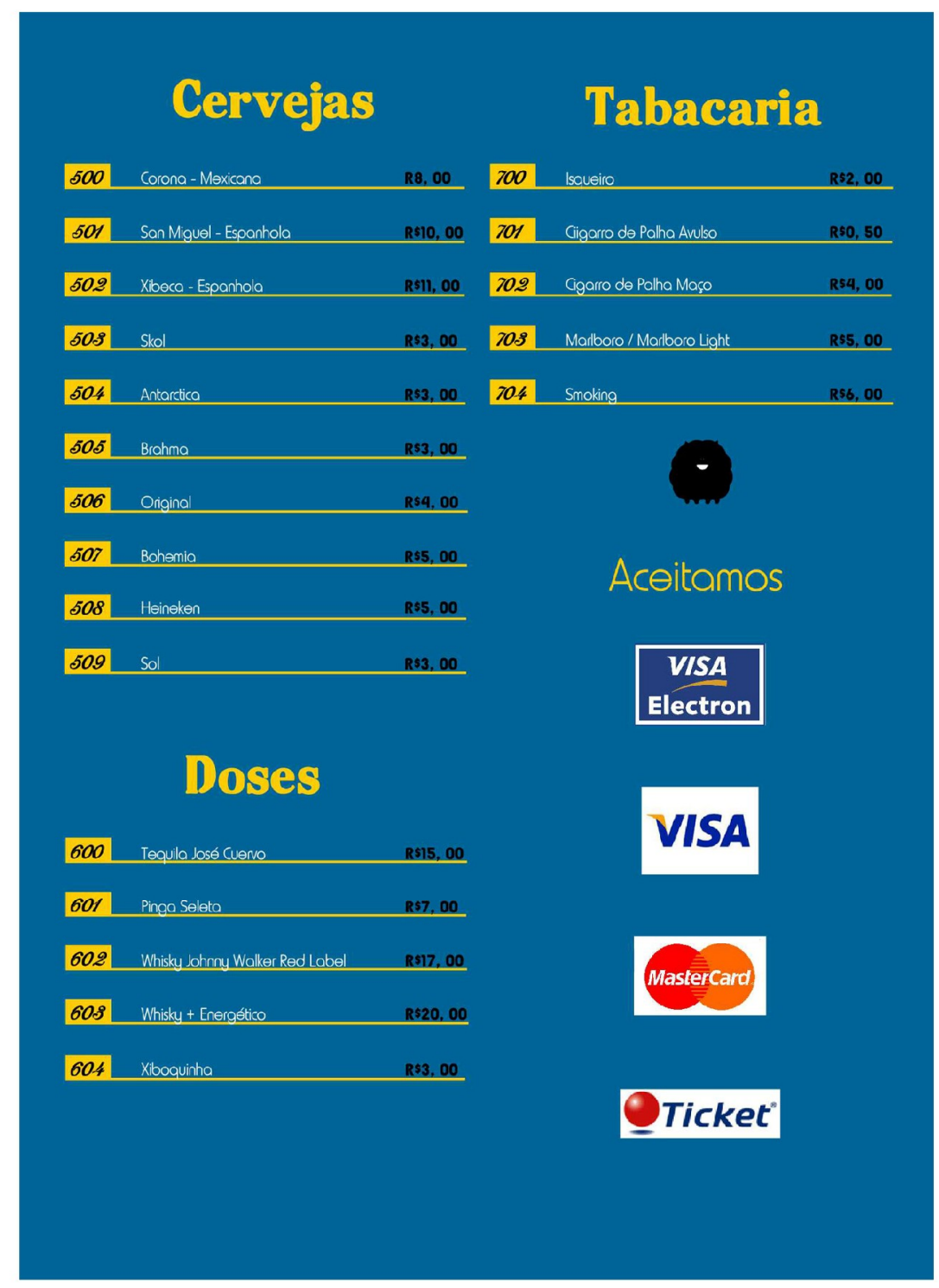

VERSO 


\section{Papelaria}

\section{Porta-copo}

Aqui representados em uma escala de 1/2, os porta-copos terão 10, 5 centímetros de diâmetro e, além do seu uso normal, serão utilizados para a divulgaçáo da marca sendo vendidos na loja do bar. Para cstimular o espírito de colccionador dos clicntes, foram criadas várias alternativas gráficas.
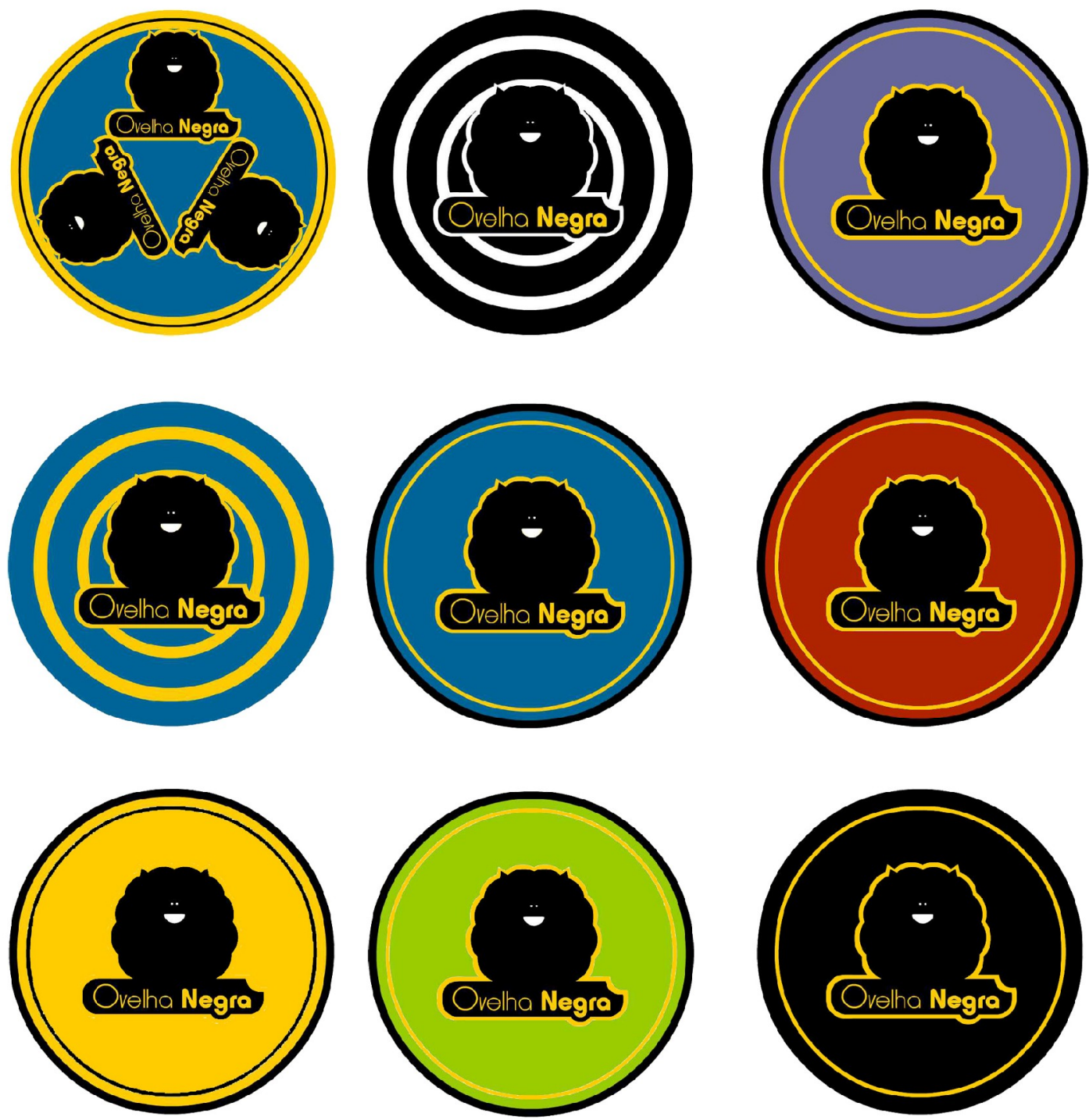


\section{Papelaria}

Jogo Americano

O jogo americano terá a mesma ilustração feita para a parede de fundo do bar. O objetivo é torná-la uma referência do bar.

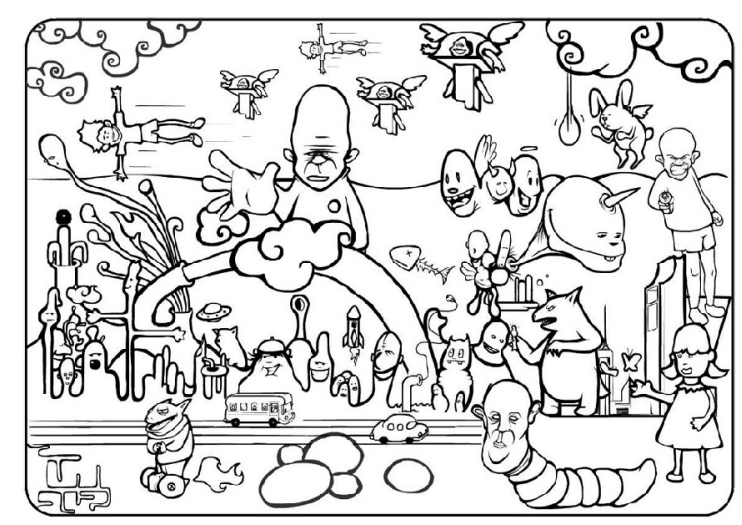

Jogo americano

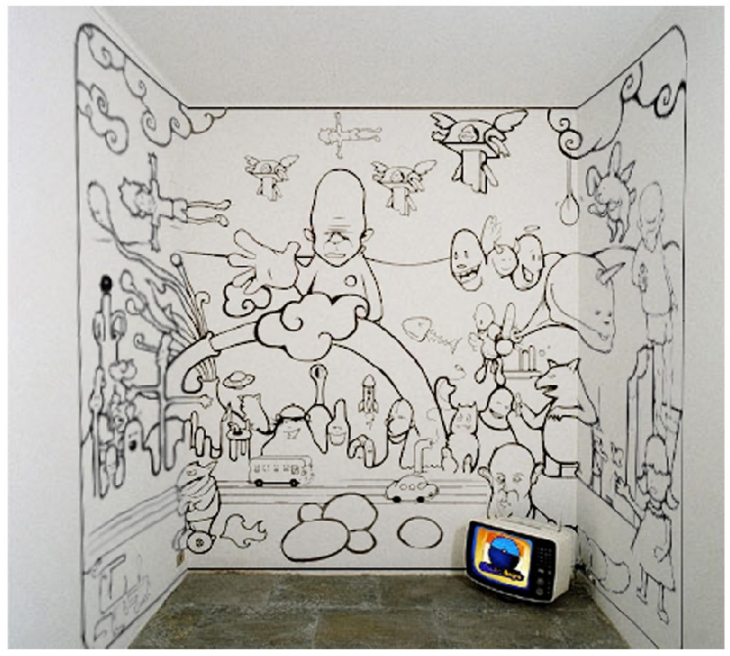

Simulação da parede de fundo 


\section{Uniforme}

Os uniformes serão usados pelos funcionários tanto garçons quanto caixas e outros empregados, como forma de aproximá-los e passar aos clientes o sentimento de unidade e fraternidade pretendido. Dessa forma também haverá uma familiaridade maior com desenho da camiseta. Ela deverá ter duas ou três listras laterias de cor amarelo-ouro, como na marca. As cores da camiseta poderão ser preto ou azul. Essas mesma camisetas também serão vendidas na loja do bar.

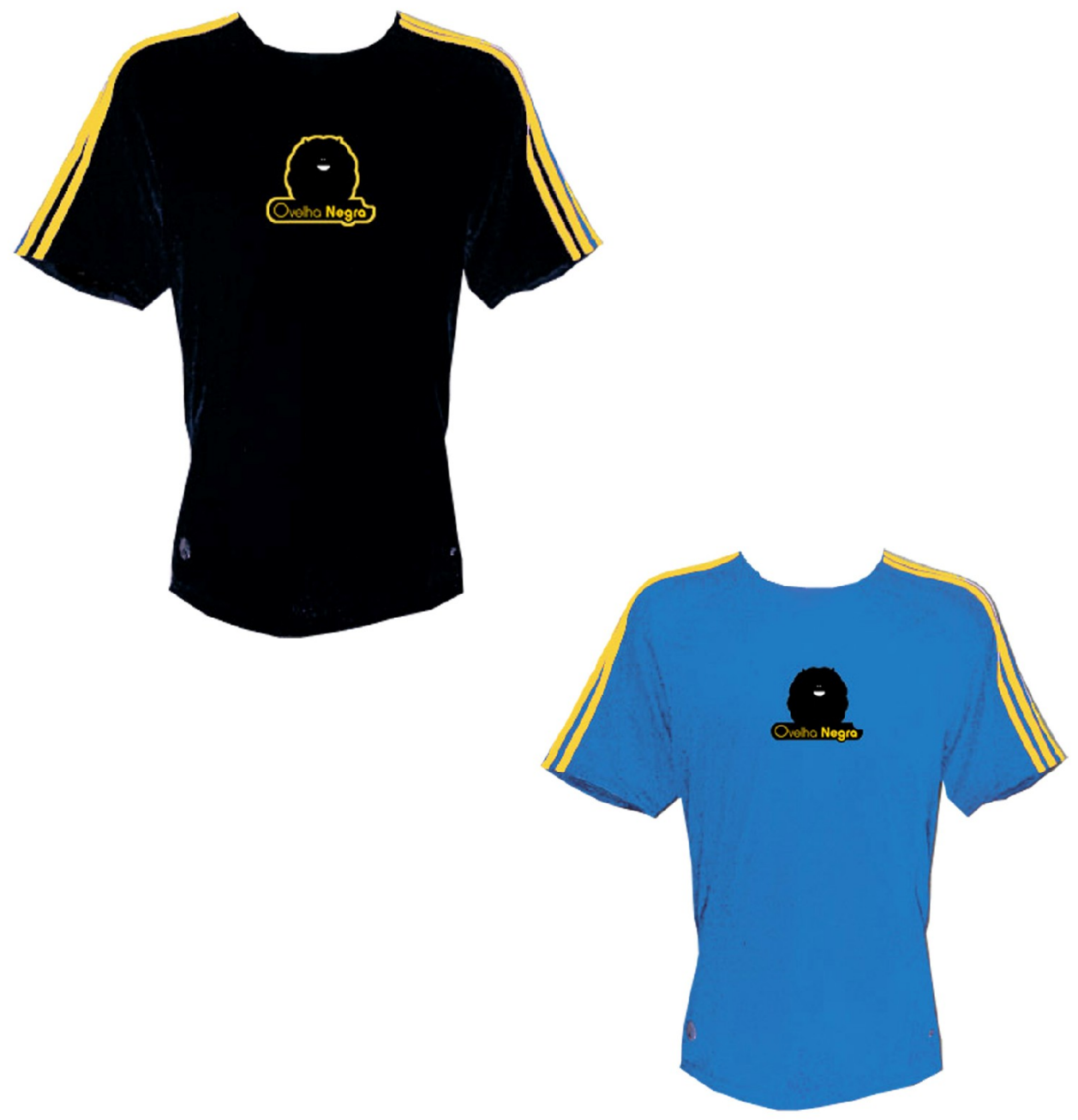




\section{Ficha Técnica}

\section{Designer Gráfico:}

Gabriel Rabelo Neves

Desenho Industrial - Programação Visual - UnB

\section{Cliente:}

Ovelha Negra Bar e Petiscaria

Responsável - Larisson da Nóbrega Nunes

Gerente de Marketing

\section{Produção:}

Adobe Flash CS3

Adobe Photoshop CS3

Electric Rain Swift 3D 
This document was created with Win2PDF available at http://www.win2pdf.com.

The unregistered version of Win2PDF is for evaluation or non-commercial use only.

This page will not be added after purchasing Win2PDF. 